UNIVERSIDADE DE SÃO PAULO

FACULDADE DE FILOSOFIA, LETRAS E CIÊNCIAS HUMANAS

DEPARTAMENTO DE CIÊNCIA POLÍTICA

ADELE MARA ALVES DE GODOY

Intervenções Humanitárias: o dilema entre ordem e justiça sob uma perspectiva normativa

V.1

São Paulo

2008 
UNIVERSIDADE DE SÃO PAULO

FACULDADE DE FILOSOFIA, LETRAS E CIÊNCIAS HUMANAS

DEPARTAMENTO DE CIÊNCIA POLÍTICA

PROGRAMA DE PÓS-GRADUAÇÃO EM CIÊNCIA POLÍTICA

\title{
Intervenções Humanitárias: o dilema entre ordem e justiça sob uma perspectiva normativa
}

\author{
Adele Mara Alves de Godoy
}

Dissertação apresentada ao Programa de PósGraduação em Ciência Política, do Departamento de Ciência Política, da Faculdade de Filosofia, Letras e Ciências Humanas, da Universidade de São Paulo, para obtenção do título de Mestre em Ciência Política.

Orientador: Prof.Dr. Álvaro de Vita

V.1 
AUTORIZO A REPRODUÇÃO E DIVULGAÇÃO TOTAL OU PARCIAL DESTE TRABALHO, POR QUALQUER MEIO CONVENCIONAL OU ELETRÔNICO, PARA FINS DE ESTUDO E PESQUISA, DESDE QUE CITADA A FONTE.

Ficha de catalogação 


\section{FOLHA DE APROVAÇÃO}

Adele Mara Alves de Godoy

Intervenções Humanitárias: o dilema entre ordem e justiça sob uma perspectiva normativa

Dissertação apresentada ao Departamento de Ciência

Política da Universidade de São Paulo para obtenção de título de mestre.

Área de concentração: Teoria Política

Aprovado em

Banca examinadora

Prof. Dr.

Instituição Assinatura

Prof. Dr.

Instituição Assinatura 
Aos meus amados pais, Geralda e Wilson 


\section{Agradecimentos}

Em primeiro lugar agradeço a Deus, que me fez permanecer firme quando quis esmorecer, lutar quando quis desistir, erguer minha cabeça quando achei que tudo estivesse perdido e demonstrando a cada dia estar presente em minha vida.

A Álvaro de Vita, que por seu voto de confiança e generosidade, tornou possível a conclusão desta dissertação e bem mais do que isso, devolveu meu prazer e gosto pela pesquisa acadêmica. Com ele aprendi que a dedicação e o empenho a esta dissertação eram os melhores remédios para esquecer as desventuras passadas.

Ao professor Fernando Limongi, por ter dado novos rumos à minha trajetória dentro do Programa de Mestrado de Ciência Política da USP. A conclusão desta pesquisa deve-se enormemente à seriedade e justeza dele para comigo.

A Amâncio Jorge de Oliveira, que foi desde o início dessa caminhada uma referência de compreensão e apoio. Em momentos de extrema necessidade, agradeço a seus ouvidos atentos e palavras de cuidado e incentivo.

A Rafael Villa, por ser meu primeiro exemplo de professor de Relações Internacionais e acadêmico. Um ícone, por quem tenho imenso carinho, talvez até desconhecido por ele, desde seus primeiros comentários de minha pesquisa de iniciação científica.

À Flávia de Campos Mello, pela leitura leal de minha qualificação, pelas valiosas sugestões e recomendações e pela postura correta e encorajadora que, sem dúvida, foram determinantes para a conclusão desta esta dissertação.

À minha mãe, Geralda, por seu exemplo de vida, força e dedicação integral à minha felicidade. A meu pai, Wilson, pelo amor mais forte, compreensivo e zeloso que posso ter. Sem a presença e apoio deles, não haveria coragem e motivação para superar os obstáculos desse percurso.

À minha 'mãe-madrinha-adotiva' Irene Vida Gala, pela divisão de minha vida em antes e depois de sua existência. Sua generosidade me fez ganhar o mundo, crescer e superar traumas que impediam meu pleno desenvolvimento intelectual e humano. E a Carlos Gala, pelo apoio irrestrito e depósito de confiança que tanto me orgulharam.

À dupla Eliana-Elaine, amigas de valor inestimável e presença indispensável nessa trajetória. A primeira por dar sentido às minhas escolhas, pensamentos e vontades e a última pelas palavras de encorajamento e pelos abraços de zelo e afeição motivadores. 
Aos meus padrinhos, Zilda e Francisco, pelo apoio e respaldo que tornaram possível minha permanência em São Paulo para dedicar-me a este trabalho.

A Capes, cujo financiamento foi essencial à minha dedicação integral ao mestrado.

A toda equipe da secretaria do departamento, em especial à Rai, por quem tenho amor de filha e de quem sempre lembrarei não só o nome, mas o valor e a integridade. Esta dissertação de mestrado deve-se muito a ela. E à doce Vívian, pela ajuda indispensável com prazos, procedimentos e angústias.

Aos queridos amigos que o mestrado me deu, Maira, Kadu, Francesca e San. Cada um contribuiu a seu modo para a realização dessa dissertação. Maira, com os momentos de amizade e 'sobrevivência'; Kadu, com os momentos de riso e descontração; Francesca, com os momentos de leveza e poesia e San, com sua generosidade intelectual, nossas conversas acadêmicas, que estão refletidas na argumentação deste trabalho e, todas as outras conversas nem tão acadêmicas assim.

À Claudia, por ter me conduzido pelas mãos até São Paulo para o mestrado em Ciência Política da USP e para o período mais rico de minha vida. A extensão de sua contribuição a essa dissertação vai da primeira à última página, passando por todo o carinho e cuidado que uma grande amizade pode ter.

À Liliam, pela lição de que a despeito do sangue podemos escolher os irmãos que teremos na vida.

Por fim, ao Lukas, por seu amor incondicional. 
GODOY, A. M. A. de. Intervenções Humanitárias: o dilema entre ordem e justiça sob uma perspectiva normativa. 2008. Dissertação (mestrado). Departamento de Ciência Política da Universidade de São Paulo, São Paulo, 2008.

\section{Resumo}

A decisão política e moral entre 'fazer algo' e 'não fazer nada' diante de emergências humanitárias, como genocídio, assassinatos em massa e limpeza étnica ao redor do mundo, permanece como um dos principais dilemas decisórios das relações internacionais e como tema controverso tanto para a Teoria Política quanto para a Teoria de Relações Internacionais. A complexidade e controvérsia deste fenômeno serão analisadas a partir da perspectiva de que as intervenções humanitárias reivindicam o lugar negligenciado das considerações morais tanto pela prática política quanto pelas reflexões teóricas de mainstream das relações internacionais. Desse modo, o principal objetivo desta pesquisa é a análise das intervenções humanitárias a partir da relação entre ordem e justiça sob a perspectiva normativa. É da reflexão sobre a conexão e a combinação dessas duas idéias tão cruciais ao entendimento prático e teórico das relações internacionais que se pretende buscar novas interpretações normativas a respeito desse fenômeno. Para tanto, a reflexão teórica e normativa das intervenções humanitárias será ilustrada com exemplos empíricos de intervenções durante e após o período de Guerra Fria, a fim de investigar as possibilidades de uma mudança no relacionamento entre ordem e justiça desde o início da década de 1990 até os dias mais contemporâneos.

Palavras-chave: Intervenções Humanitárias - Ordem Internacional - Justiça Internacional Direitos Humanos - Ética e Moral 
GODOY, A. M. A. de. Humanitarian Interventions: the dilemma between order and justice in a normative perspective. 2008. Dissertation (Master Degree). Departamento de Ciência Política da Universidade de São Paulo, São Paulo, 2008.

\begin{abstract}
The moral and political decision between "doing something” and "doing nothing” at the occasion of humanitarian emergencies, such as genocide, mass murders and ethnic cleansing all around the world remains to be the principal dilemma of decision making in the area of international relations and as a controversial subject as well as for the Political Theory as for the Theory of International Relations. The complexity and controversy of this phenomenon will be analyzed from the perspective that the humanitarian interventions demand the neglected place of moral considerations as well as for the political practice as for the theoretical reflections of the mainstream of international relations. In this manner, the main objective of this research is the analysis of humanitarian interventions from the relation between order and justice on a normative perspective. It is the reflection of connection and combination between this two ideas so much essential for the practical and theoretical understanding of international relations, that will be the groundwork for the search for new normative interpretations in relation to this phenomenon. As such, the theoretical and normative reflection of humanitarian interventions will be illustrated on empirical examples of interventions during and after the period of Cold War, to investigate the possibilities of changes in relation between order and justice since the beginning of the decade of 1990 until the more recent past.
\end{abstract}




\section{SUMÁRIO}

Introdução ................................................................................................................................................... 12

Capítulo I - As intervenções humanitárias e o dilema entre ordem e justiça....................21

1.1. O “dilema” entre ordem e justiça: definindo os termos do debate ...........................21

1.1.1. Da anarquia à sociedade anárquica: ordem pluralista como fato e valor .........21

1.2. O lugar e a definição da justiça na ordem internacional.........................................26

1.2.1. A justiça da ordem internacional pluralista do pós II Guerra Mundial ............26

1.2.2. Desafios à ordem internacional pluralista: impactos e transformações do fim do

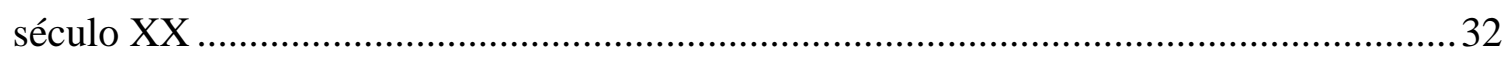

1.2.3. Novos referenciais para a justiça? A soberania como responsabilidade de

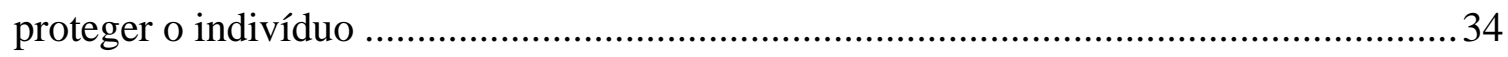

1.2.4. Estabelecendo critérios para a legitimidade das intervenções humanitárias: a proposta solidarista de reconciliação de ordem e justiça................................................... 39

1.2.5. Três ciclos de responsabilidade: dialogando com a proposta prática de Saving Strangers

1.2.6. Reconciliando ordem e justiça. 50

Capítulo II - O ceticismo moral nas relações internacionais: objeções realistas e pluralistas às intervenções humanitárias ..................................................................52

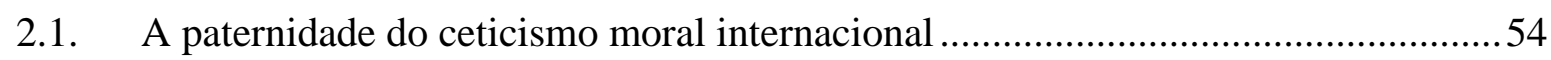

2.2. As relações internacionais como um estado de natureza hobbesiano ......................57

2.2.1. A função preditiva da concepção de relações internacionais como um estado de natureza hobbesiano: o estado de guerra 57

2.2.2. A função prescritiva da concepção de relações internacionais como um estado de natureza hobbesiano: o interesse nacional 64

2.3. Premissas realistas para o ceticismo moral e ético internacional ............................65

2.4. As objeções da teoria realista às intervenções humanitárias ...................................69

2.5. A objeção pluralista às intervenções humanitárias.................................................... 70 
2.6. Ordem versus iustiça na intervenção indiana de 1971: a estréia dos motivos humanitários e a prevalência da ordem

2.7. A intervenção do Vietnã no Camboja: mais um ‘triunfo’ da ordem sobre a justiça?....

2.8. A intervenção da Tanzânia em Uganda: o problema do silêncio e da seletividade.. 79

2.9. É possível falar em intervenções humanitárias durante a Guerra Fria? 82

Capítulo III - As intervenções humanitárias da década de 1990: o quanto uma possível “expansão da ambição normativa” pode reconciliar ordem e justiça? . .86

3.1. Intervenções humanitárias na década de 1990: rumo a uma 'expansão da ambição normativa’ solidarista?

3.1.1. A força para aliviar a fome: a ONU e os EUA na Intervenção Humanitária da Somália 87

3.1.2. A mais vergonhosa paralisia: a sociedade internacional como observadora do genocídio em Ruanda em 1994 103

3.1.3. Recobrando as esperanças normativas: a intervenção da OTAN no Kosovo. 115 3.2. É possível falar em uma 'expansão da ambição normativa' relacionada à justiça na sociedade internacional?

3.2.1. Normas e legitimidade: possibilidades de novo contexto normativo na

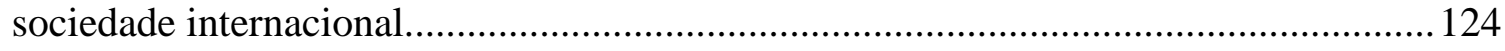

3.2.2. Investigando as intervenções humanitárias como norma global .....................127

3.2.3. Possibilidades e limites de uma norma da intervenção humanitária ............... 131

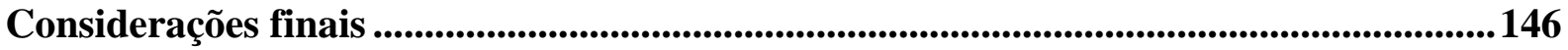

Referências bibliográficas ...............................................................................................154 


\section{INTRODUÇÃO}

Desde o fim do mês de agosto, o mundo tem tomado conhecimento, lenta e desatentamente, do conflito no leste da República Democrática do Congo, onde um grupo de rebeldes tutsis congoleses, comandados pelo general Laurent Nkunda, iniciou uma ofensiva na região, ameaçando tomar Goma, a capital da província de Kivu Norte. A presença da Força Democrática de Libertação de Ruanda (FDLR), constituído essencialmente de hutus - antigos soldados revolucionários ruandeses e de milicianos interahamwe - provoca a desestabilização do leste congolês. O general Nkunda acusa o governo congolês de não cumprir com suas promessas de expulsar as milícias hutus ruandesas, responsáveis pelo genocídio no ano de 1994 em Ruanda. Mais veementemente, Nkunda acusa o Presidente congolês de apoiar tais milícias, que, segundo ele, após terem sido derrotadas em Ruanda, atravessaram a fronteira para encontrar um 'santuário’ no Leste do Congo.

O governo do Congo, por sua vez, nega o apoio à FDLR embora dois fatores importantes possam justificar a colaboração contínua de Kinshasa com os rebeldes hutus ruandeses. O primeiro fator seria a forte vontade de vingar-se do governo do Congo, após as duas guerras regionais iniciadas por Ruanda; o segundo fator, por sua vez, seria a inexistência de um exército nacional congolês capaz de conter a insurgência das forças tutsis do general Nkunda, que contam com a vantagem de recrutar jovens soldados dentro dos campos de refugiados tutsis e entre os contingentes desmobilizados do exército ruandês.

As forças tutsis insurgentes no Congo estão conscientes de que sua maior vantagem está na manipulação da culpa ocidental pelo genocídio dos tutsis em Ruanda no início da década de 1990. O general Nkunda destaca o temor de uma similar vitimização dos tutsis no Leste do Congo para encobrir as inúmeras ações violentas de suas tropas que vão desde saque de mercadorias e alimentos até estupros em massa e assassinatos cruéis.

Por outro lado, o Congo responsabiliza Ruanda, país vizinho, pelas ações das forças rebeldes do general insurgente. O controle dos minerais do leste do Congo estaria motivando o apoio do governo ruandês à Nkunda. Além do desejo pelos recursos minerais do Congo, que seriam designados a acelerar a economia ruandesa, também haveria indícios de que o apoio poderia relacionar-se à questão do crescimento populacional de Ruanda, que já sofre com a escassez de terra e alimentos para a sua atual população de cerca de 8.3 milhões de pessoas 
(número que tende a dobrar para 16 milhões de ruandeses até 2020). Segundo essa perspectiva, oficialmente negada pelo governo ruandês, o general Nkunda e suas milícias assegurariam terras no Congo para acomodar essa população. Por fim, dentre as razões que explicariam o apoio ruandês ao general Nkunda, estaria a intenção de concluir a 'limpeza étnica’ dos distritos hutus de Rutshuru e Masisi, no leste do Congo.

A deflagração do conflito já provocou uma grave crise humanitária no país, com o deslocamento de mais de duzentas mil pessoas, que devem juntar-se ao gritante número de um milhão e duzentas mil pessoas que já se encontram em campos de refugiados; sem contar as cinqüenta mil que foram expulsas dos campos onde viviam no rastro da ação violenta das forças rebeldes do general Nkunda. Em suma, essa ofensiva gerou uma quantidade exacerbada de desalojados num ambiente de extrema umidade, frio, escassez de abrigo, alimentos e fácil contaminação e propagação de doenças, após uma onda de assassinatos, saques e estupros.

Diante do agravamento da crise humanitária no país, as Organizações NãoGovernamentais (ONGs) internacionais, como a Federação Internacional de Ligas de Direitos Humanos (FIDH), a Cruz Vermelha, a Save the Children, entre outras, já manifestaram a ampliação da preocupação com as dimensões humanitárias do conflito. A FIDH já denunciou que as "graves violações em massa dos direitos humanos" ocorridas no leste da República Democrática do Congo (RDC) deveriam ser investigadas publicamente pela Corte Penal Internacional (CPI). A Cruz Vermelha, por sua vez, já declarou que a situação é de uma verdadeira catástrofe humanitária, em que assassinatos e estupros são uma constante e a ajuda humanitária não chega aos desabrigados.

As constatações de que uma verdadeira catástrofe humanitária está ocorrendo no Congo tornam patente a incapacidade estatal de garantir e proteger os direitos básicos de seus cidadãos, em especial daqueles ligados à preservação da vida e às condições mínimas de sobrevivência, como alimentação e abrigo. Restaria então aos cidadãos esperar que o efetivo de dezessete mil soldados da Operação de Paz da ONU no Congo (Monuc) pudesse exercer tal tarefa. Contudo, as forças da ONU declararam-se sobrecarregadas e sem instrumentos em seu mandato para exercer uma maior capacidade ofensiva e de contenção à violência em direção a alvos civis. 
Nesse contexto, o Ministro das Relações Exteriores da França defendeu que o mandato da Monuc seja repensado, no sentido de atribuir mais força e alcance às ações em campo. "What should be done when people are being killed?”, o Ministro francês questionou. Segundo ele, frente às regras insuficientes e muito restritivas do mandato da atual Operação de paz: "We need different soldiers, and different rules of engagement". "We need more of an offensive capability." O Primeiro-Ministro britânico por sua vez declarou: "We must not allow Congo to become another Rwanda", proferindo talvez a mais representativa declaração, dentre as manifestações dos principais líderes mundiais a respeito da grave situação humanitária na República Democrática do Congo.

Considerando ser possível manter toda a contextualização do conflito no Congo, com a omissão de datas, sem a identificação dos locutores e sem a atribuição das fontes, a partir de um exercício lógico e intuitivo, seria bastante provável imaginar que toda a situação descrita estivesse inserida histórica e temporalmente na década de maior ocorrência das intervenções humanitárias - a década de 1990 - não fosse o fato de que ela pertence à realidade mais recente de nossos dias, comprovada pela atribuição das datas, fontes e locutores. O conflito na República Democrática do Congo exposto acima teve início em agosto de 2008; o PrimeiroMinistro britânico citado é Gordon Brown e sua afirmação data do último dia 01 de novembro de 2008 ${ }^{1}$; o Ministro das Relações Exteriores da França é Bernard Kouchner; assim como todas as informações sobre o conflito, números e pronunciamento das ONGs internacionais foram retirados de artigos provenientes da mídia nacional e internacional no período de 01 a 04 de novembro de 2008.

A singularidade da década de 1990 como o período em que ocorreram as mais emblemáticas intervenções humanitárias não é contestável, nem mesmo é possível negar a importância do que foi produzido academicamente a respeito delas desde a chamada 'era das intervenções’. Ao contrário, o que se pretende mostrar é que, independente da aprovação ou anuência do Conselho de Segurança (CS) da Organização das Nações Unidas (ONU) para que novas intervenções aconteçam, catástrofes humanitárias que justificariam novas intervenções infelizmente não ficaram circunscritas àquele período. Junto a isso, a inexistência de consenso ou conclusões diante da complexidade da decisão política e moral de intervir mantém a possibilidade, ou melhor, a necessidade de novos escrutínios sobre o tema.

\footnotetext{
1 'We must act on Congo', The Australian, 02/11/08.
} 
O fato de que nenhuma intervenção humanitária foi aprovada nos moldes da Somália (1992), Ruanda (1994) e Kosovo (1998) pelo CS das Nações Unidas (CSNU) após o fim da década de 1990, juntamente com o grande interesse e a conseqüente produção acadêmica gerada sobre as intervenções humanitárias nesse período - em especial sobre sua legalidade jurídica $^{2}$ - parece ter gerado a equivocada impressão de que os anos 1990 haviam confinado a importância do tema ou mesmo esgotado a necessidade de repensá-lo a partir de novas perspectivas interpretativas.

Ainda é de amplo conhecimento de que o debate em torno das intervenções humanitárias perdeu impacto e lugar na agenda internacional para a preocupação com o terrorismo, após os atentados aos Estados Unidos em 11 de setembro de 2001, embora o dilema político e moral entre "não fazer nada” e "fazer algo" diante das emergências humanitárias espalhadas pelo globo não tenha sido solucionado, como já mostrava o Sudão, com a terrível situação humanitária em Darfur e como mostrou, veloz e assustadoramente, a República Democrática do Congo. Apesar desse enfraquecimento do debate a respeito das intervenções, a permanência dos dilemas a respeito da normatividade do tema que abrange desde a justificação da intervenção humanitária até as considerações sobre a legitimidade do recurso à força, continua sustentando a tarefa de aprofundar as análises já realizadas, no intuito de encontrar seus limites e contribuições ainda não explorados.

\footnotetext{
"Intervention is a very central and a very old subject in the study of international relations, and there is a sense in which there is nothing new that can be said about it. But at the same time it is one of those subjects which we have constantly to reassess, in relation to changing circumstances: the underlying questions may be the same, but they keep arising in new forms and being viewed from fresh perspectives”. (BULL, 1984, p. V)
}

As diferentes circunstâncias que atuaram nesse caso para a mobilização de novas perspectivas relacionadas às intervenções humanitárias se referem à opção de não pautar os objetivos deste trabalho pelo debate da existência ou não de um direito ou dever à intervenção humanitária, mas sim pela intenção de privilegiar os aspectos e a influência das considerações morais sobre a política, num processo de legitimidade que tais ações parecem ter adquirido

\footnotetext{
${ }^{2}$ Conferir essas obras em: WELSH, 2004, p. 189.
} 
especialmente a partir da comparação entre o período de Guerra Fria e a década de 1990, apesar da intensa controvérsia em torno de sua ${ }^{3}$ legalidade.

"Many academic discussions focus on the question of whether there is a legal right of humanitarian intervention, giving insufficient attention to the underlying ethical issues, the politics within international organizations and coalitions, and the practical dilemmas faced by international actors - before, during, and after intervention”. (WELSH, 2004, p. 01)

A mobilização de construções teóricas que privilegiam os aspectos e argumentos normativos em detrimento das análises que acabam por restringirem-se à contraposição entre a legalidade internacional, baseada na carta da ONU, e legitimidade moral das intervenções, tem como fundamento a percepção de que a análise e a reflexão sobre o dever ser das relações internacionais não só contribuem significativamente para a análise do que de fato é a realidade internacional, mas também para a investigação do que essa realidade poderia ser.

Nesse sentido, a inspiração e o embasamento teórico definidores deste trabalho são provenientes da produção acadêmica que enxergou nas intervenções humanitárias a possibilidade de novos entendimentos normativos a partir de uma interpretação conciliatória da relação entre ordem e justiça. Dentre essas propostas, a obra Saving Strangers (2000) de Nicholas Wheeler, representante da vertente solidarista da Escola Inglesa de Relações Internacionais, foi o referencial primário para essa investigação. Estudar as intervenções a partir das proposições solidaristas direcionou este trabalho para a importância das questões morais e de uma possível expansão normativa em direção a normas mais solidaristas na sociedade internacional.

A proposta normativa de reconciliação entre ordem e justiça de Saving Strangers alia a observação e análise da empiria às preocupações e proposições normativas. Num primeiro momento, Wheeler parte da investigação de três casos empíricos de intervenção unilateral para avaliar as possibilidades normativas da intervenção humanitária da década de 1970. Num segundo momento, o autor inicia sua análise dos casos de intervenção humanitária da década de 1990, com a finalidade de investigar em que medida as intervenções humanitárias foram aceitas e legitimadas naquele período pelos mesmos Estados e pela ONU que condenaram as

\footnotetext{
${ }^{3}$ A investigação de Wheeler com relação à legitimidade das intervenções humanitárias pretende investigar se as intervenções são um código implícito de mitigação do Direito Internacional ou um grupo de exceções legais, baseadas no Direito Internacional costumeiro. Além disso, o interesse do autor em investigar a legalidade das intervenções humanitárias deve-se à sua percepção de que Direito representa a integração da autoridade com o poder, especialmente do poder que é legítimo, justamente porque é estabelecido a partir de normas compartilhadas. Para maiores detalhes a respeito dessa investigação, conferir em: WHEELER, 2000, p.03.
} 
ações da Índia (1971), Vietnã (1979) e Tanzânia (1979). Desse modo, o conjunto entre teoria e empiria foi essencial para a compreensão da principal investigação dessa obra, ou seja, da possibilidade de considerar uma expansão da ambição normativa solidarista na sociedade internacional a partir das intervenções humanitárias. A partir da proposição solidarista de Wheeler, outras contribuições tanto de conteúdo teórico quanto empírico foram incorporadas ao trabalho com a intenção de aprofundar e identificar os avanços e os limites do que foi proposto em Saving Strangers.

Nesse sentido, o principal objetivo desta pesquisa é analisar as contribuições e os limites da proposta solidarista de reconciliação entre ordem e justiça nas intervenções humanitárias, assim como investigar em que medida é possível considerar essa "expansão da ambição normativa" 4 como algo consistente e duradouro para a sociedade internacional. Dessa maneira, o trabalho pretende investigar o alcance da interpretação de que as intervenções humanitárias, apresentadas com exemplos empíricos durante e após a Guerra Fria, contribuíram para a construção de uma nova possibilidade na relação entre ordem e justiça. O reexame da conexão entre duas idéias tão cruciais ao entendimento prático e teórico das relações internacionais pretende explorar novas perspectivas e nuances de uma interpretação baseada no aspecto normativo das intervenções humanitárias.

Para alcançar o objetivo deste trabalho, portanto, o primeiro momento da análise, realizado no capítulo I, investigará em que medida esse dilema entre ordem e justiça pode se entendido e questionado, tanto do ponto de vista empírico quanto do teórico. O objetivo inicial, portanto, é de entender em que termos e sob que perspectivas essa relação pode ser definida. Esse capítulo tem como principal tarefa esclarecer sobre qual ordem e qual justiça as intervenções humanitárias se referem. Na parte final do capítulo, a proposta de prática legítima das intervenções humanitárias, formulada em Saving Strangers, será apresentada e, posteriomente, debatida a partir do conceito de soberania como responsabilidade, bem como do relatório internacional "Responsabilidade de Proteger". 5

O capítulo II reunirá as posições de objeção realista e pluralista ao reconhecimento das intervenções humanitárias como prática legítima nas relações internacionais. Duas grandes características servirão como os elos necessários para reunir essas duas perspectivas teóricas

\footnotetext{
${ }_{5}^{4}$ Cf. em HURRELL, 2003.

${ }^{5}$ Relatório do International Commission on Intervention and State Sovereignty (ICISS) - Comissão Internacional sobre Intervenção e Soberania Estatal (CIISE), Toronto, 2002.
} 
na mesma análise. Serão elas: o fato de que a base de tais objeções é a centralidade do Estado e do paradigma estatal, estabelecendo por conseqüência a centralidade das questões ligadas à ordem em detrimento da justiça. Seguida pela consideração de que, uma vez existindo preocupações morais, elas correspondam estrita e unicamente à moralidade do Estado. Sob a perspectiva empírica, os casos de intervenção analisados serão as seguintes intervençõaes unilaterais: Índia (1971), Vietnã (1979) e Tanzânia (1979) correspondentes ao período de Guerra Fria. A análise desses casos busca avaliar a utilização e o impacto das objeções realistas e da objeção pluralista às intervenções humanitáris, que determinaram que esses casos não fossem considerados a partir do resultado humanitário positivo que geraram, mas da infração das normas de não-intervenção e não-uso da força, bem como do princípio de soberania que cometeram.

O capítulo III, por sua vez, parte da análise dos casos de intervenção humanitária na Somália (1992), em Ruanda (1994) e no Kosovo (1998), no intuito de descobrir como a sociedade internacional mudou sua postura frente às intervenções cujos motivos eram alegadamente humanitários. A aprovação da ONU, conferindo legitimidade à esses casos, inaugurou um novo período de atuação do Conselho de Segurança (CS) da Organização, no qual as prerrogativas e responsabilidades do CS foram ampliadas no sentido de considerar graves emergências humanitárias como ameaça a paz e a segurança internacionais, segundo o Capítulo VII de sua Carta constitutiva.

Após essa análise de base empírica, a segunda parte do capítulo III concentra-se na parte teórica que pretende avaliar em que medida a legitimidade, conferida aos casos de intervenção humanitária da década de 1990, indica um processo de expansão da ambição normativa em direção a normas mais solidaristas da sociedade internacional. Do mesmo modo, essa segunda parte de capítulo pretende investigar a correspondência entre essa mudança de contexto normativo e a proposta solidarista de reconciliação entre ordem e justiça na concepção da intervenção humanitária como norma. Para tanto, um breve estudo das normas e da legitimidade proveniente delas também será realizado na segunda parte desse capítulo buscando reunir os avanços e limites de pensar as intervenções humanitárias a partir de uma perspectiva normativa.

Em conjunto, os capítulos II e III responderão pelo esforço de analisar o processo de surgimento, desenvolvimento e ápice da mobilização do argumento humanitário para justificar uma intervenção externa em um Estado soberano com uso da força, bem como a 
influência dessa mobilização para uma possível recombinação ou reposicionamento das idéias de ordem e justiça na prática política da sociedade internacional como um todo.

Por fim, o último capítulo conterá as considerações finais deste trabalho, com um balanço crítico das perspectivas normativas investigadas. O que se pretende é verificar a possibilidade de confirmar o argumento de uma “expansão da ambição normativa” da sociedade internacional, a partir da reivindicação de um lugar para as preocupações morais no plano internacional, bem como de uma nova combinação entre a intenção de manter a ordem e o desejo de promover a justiça.

Antes de passarmos ao capítulo I, é necessário fazer duas breves observações elucidativas a respeito dos termos no qual a análise irá ocorrer, ainda mais por se tratar de um tema tão complexo e cheio de nuances como as intervenções humanitárias.

A primeira dessas observações é que o desafio analítico das intervenções humanitárias já se inicia na própria definição conceitual desse fenômeno. Diante disso, a primeira ressalva a fazer é que a análise desse conceito não está entre os objetivos e preocupações principais desse trabalho, não porque esse esforço seja inválido, mas porque essa tarefa já foi devidamente abraçada anteriormente por outros inúmeros trabalhos acadêmicos.

Tendo em vista as diversas definições de intervenção e de intervenção humanitária, a opção foi lidar com a questão conceitual definindo as considerações básicas a respeito das intervenções que delimitavam e constituíam o tipo de intervenção humanitária que mais se adequava às preocupações desse trabalho.

Nesse caso, a escolha foi elencar as considerações básicas sobre o tipo de intervenção humanitária que esse trabalho se propõe a analisar. Essas considerações são as seguintes:

I. O uso da força é a condição e a característica definidora das intervenções humanitárias analisadas;

II. A intervenção será considerada humanitária quando o seu propósito for prevenir ou cessar graves violações de direitos humanos básicos de uma população no interior de um Estado soberano.

III. A intervenção humanitária poderá ser feita por um Estado, por um grupo de Estados ou por forças internacionais; 
IV. A intervenção humanitária não precisará observar a condição legal6 do nãoconsentimento do Estado objeto da ação militar em questão;

V. A intervenção humanitária poderá ser multilateral ou unilateral. Dessa forma, serão consideradas intervenções multilaterais e, portanto, também legais àquelas intervenções que forem aprovadas e autorizadas por resolução do Conselho de Segurança da ONU, sob o Capítulo VII da Carta da Organização;

Sendo assim, as intervenções humanitárias analisadas observam essas cinco características reunidas acima.

Em referência a condição legal do consentimento, mesmo os casos que tiveram um grau mínimo de consentimento do Estado que recebeu a intervenção, seja por determinado período de sua duração, seja somente por algumas partes ou facções políticas componentes do governo desse Estado, serão considerados casos de intervenção. Os casos de intervenção dos anos 1990 demonstraram que o requisito legal do 'não-consentimento' é, na prática, muito difícil de ser mantido ou observado, particularmente quando o consentimento é ambíguo ou sob coerção. (WELSH, 2004, p. 3)

Outro ponto válido para esclarecimento é a diferenciação das intervenções humanitárias como ação coercitiva no interior de um Estado soberano para cessar graves emergências humanitárias daquelas intervenções também denominadas humanitárias realizadas pelas agências de ajuda humanitária e ONGs internacionais. Essas ações humanitárias em situações de emergência, como os desastres naturais, que caracterizam a assistência ou auxilio humanitário não farão parte da definição de intervenção humanitária desse trabalho, que ficará restrita aos casos em que houver uso da força militar. Além disso, tanto as intervenções autorizadas pela ONU, quanto às intervenções unilaterais, ou seja, realizadas sem a aprovação da CSNU, serão consideradas intervenções humanitárias na análise a seguir.

\footnotetext{
${ }^{6}$ A definição legal básica de intervenção humanitária do Direito Internacional define intervenção humanitária pelo seguinte: "the use of armed force by one or more states or international bodies in another state without the consent of its authorities with the purpose of prevening widespread suffering or death among the inhabitants". (ABIEW apud WELSH, 2004, p. 3)
} 


\section{CAPÍTULO I - AS INTERVENÇÕES HUMANITÁRIAS E O DILEMA ENTRE ORDEM E JUSTIÇA}

Referir-se à tensão entre ordem e justiça equivale a referir-se às dificuldades de buscar soluções para os problemas relacionados à ordem e, concomitantemente, à necessidade de solucionar os problemas relacionados à justiça. (KOSKENNIEMI, 1995, p.328) Em outras palavras, o referido dilema que tem constituído e estruturado grande parte do pensamento internacional poderia ser definido por meio da dificuldade de promover as condições para a ordem e, simultaneamente, possibilidades de justiça.

O principal intuito deste capítulo é iniciar a análise a respeito desse pretenso dilema, começando por apresentar nas seções seguintes os entendimentos a respeito da relação entre ordem e justiça, com base das intervenções humanitárias. O argumento solidarista parte da premissa que a legitimidade das intervenções humanitárias da década de 1990 permite que se considere o desenvolvimento de uma nova estrutura normativa com relação às intervenções humanitáris rumo a normas mais solidaristas.

A proposta solidarista, nesse sentido, indica algumas possibilidades para que a relação de ordem e justiça ultrapasse a concepção de dilema. Sob a perspectiva de que é possível reconciliar ordem e justiça, essa proposta pretende investigar o quanto essa mudança normativa relacionada às intervenções humanitárias pode representar uma relação de reconciliação entre ordem e justiça, na qual a última não esteja mais meramente subordinada e subjugada à manutenção da primeira.

\subsection{O “dilema” entre ordem e justiça: definindo os termos do debate}

\subsubsection{Da anarquia à sociedade anárquica: ordem pluralista como fato e valor}

Pensar a ordem, estritamente no caso da ordem como fato, isto é, como elemento de estabilidade, de previsibilidade, ocupa diferentes lugares e exerce diferentes papéis dentro das correntes teóricas das relações internacionais. É justamente essa diferença que torna espessa e complexa a linha aparentemente tênue que separa o entendimento de ordem proveniente das preocupações realistas com a anarquia da formulação de ordem a que os pluralistas se 
debruçam. No entender dessa pesquisa, o pensamento sobre ordem não pode prescindir de pensar a ordem pluralista, em especial a ordem pluralista de Hedley Bull. Contudo, não se poderia prescindir de pensar essa ordem como resultado de uma passagem, de um passo adiante com relação a uma proposta anterior, leia-se à proposta realista.

O próprio Bull partiu da anarquia realista para definir sua sociedade anárquica e o próprio conceito de ordem. As críticas que qualificam Bull e seu trabalho como realistas têm exatamente esse ponto de partida em mente. Ao partir do realismo, Bull assinala com continuidade em relação a essa perspectiva e não com rompimento, segundo esse posicionamento que coloca o entendimento de ordem em paralelas tênues entre realistas e pluralistas. O ponto de partida da presente discussão de ordem se mantém, embora não seja para reiterar a posição desses críticos. Ao contrário, apesar de entender que a ordem pluralista pode entendida como resultado de uma passagem das preocupações realistas para preocupações pluralistas, isso não converte o pluralismo em realismo disfarçado. A tenacidade da separação dessas perspectivas não se confirma, uma vez que estas não dividem as mesmas intenções e objetivos, bem como não desenvolvem respostas tão similares e contínuas como usualmente se afirma.

O pensamento realista nasce imerso na preocupação com a anarquia internacional, ou seja, com as conseqüências para a coexistência dos Estados da ausência de um soberano supremo acima de todas as comunidades políticas. A partir desse contexto, em que não há entidade soberana capaz de exercer no plano internacional as funções de um Estado perante sua sociedade, os realistas estão empenhados em pensar uma possível estabilidade entre os Estados, onde a sobrevivência esteja equacionada com a liberdade de ação política e que a guerra seja um recurso legítimo, mas não prática corriqueira.

Para o realismo, a política internacional anárquica, ou seja, com fracos consensos e sem autoridade soberana legítima com monopólio da força, é a manifestação do fenômeno da luta pelo poder.

“O poder, mesmo que limitado e qualificado, representa o valor que a política internacional reconhece como o valor supremo. A prova a que as decisões políticas internacionais devem estar sujeitas refere-se, portanto, à medida em que essas decisões afetam a distribuição do poder”. (MORGENTHAU, 2003, p. 82) 
O poder, segundo o realismo, entendido como valor supremo na política internacional define tanto o interesse nacional dos Estados quanto as preocupações com a distribuição e o equilíbrio desse poder no ambiente anárquico. É da anarquia que surge a idéia de equilíbrio de poder, isto é, de “uma política para um certo estado de coisas real, em que o poder é distribuído entre várias nações, com uma igualdade aproximada”. (MORGENTHAU, 2003, p. 322)

Essa política regulatória do equilíbrio de poder tem como propósito manter a estabilidade do sistema, sem destruir a multiplicidade dos elementos que o compõem. Além da estabilidade, portanto, esse propósito incorpora o sentido de preservação de todos os elementos do sistema, evitando que um elemento conquiste a supremacia sobre os demais.

“O meio utilizado para manter o equilíbrio de poder consiste em permitir que os diferentes elementos sigam normalmente suas tendências conflitantes, até o ponto em que a tendência de cada um deixe de ser suficientemente forte para superar a tendência dos demais, mas bastante vigorosa para impedir que as demais a subjuguem”. (MORGENTHAU, 2003, p. 324)

Nesse sistema anárquico em que a estabilidade é confiada ao mecanismo de equilíbrio de poder, pensar em ordem dentro do realismo é pensar em ordem como fato e, conseqüentemente, é pensá-la ligada ao mecanismo do equilíbrio de poder, o qual estabelece condições mínimas para a coexistência dos Estados. O esforço de pensar a ordem dentro da formulação realista, portanto, não é prioritário. O próprio termo ordem não é próprio dos escritos realistas. A preocupação prioritária é com a anarquia e com as condições de coexistir no ambiente anárquico, o que leva a definição de ordem dentro do realismo à noção de mínima coexistência.

Dentro dessa abordagem, não há a espaço para a introdução de considerações sobre possíveis valores compartilhados ou mesmo sobre as condições necessárias para a promoção de alguma visão compartilhada no tocante à organização mais apropriada da sociedade internacional. Em uma ordem pensada em termos realistas, não há espaço para valores compartilhados, porque aos Estados - principais agentes da ordem - não há sentido em nada que ultrapasse as considerações céticas e de poder ligadas ao interesse nacional, cuja intenção básica e fundamental é a própria sobrevivência do Estado. 
Caso a definição de ordem realista mínima fosse adotada, o objeto de pesquisa em questão, isto é, as intervenções humanitárias transformar-se-iam, de pronto, em nomenclatura meramente retórica, cujo objetivo seria obscurecer e escamotear, única e simplesmente, o interesse nacional daqueles Estados que usam a força para intervir em outros Estados a fim de projetar poder e obter recursos de toda natureza. A opção pela ordem realista endossaria o coro da grande maioria de céticos, para os quais as relações entre os Estados está baseada em uma idéia tão restritiva que não permite considerações mais abrangentes do que a manutenção de uma relação de coexistência. Também seria, logo de início, aceitar reproduzir sem maiores objeções grande parte da produção de mainstream da teoria de relações internacionais a respeito das intervenções humanitárias, desconsiderando os fortes indícios que os casos empíricos apresentam de que a complexidade da resolução do dilema de intervir ultrapassa as considerações estreitas do interesse nacional.

O trabalho de Hedley Bull, em Uma Sociedade Anárquica, tem como objetivo pensar a ordem prioritariamente, o que significa pensá-la não como conseqüência, mas como fim. ${ }^{7}$ De início, essa motivação já diferencia e adensa a linha considerada tênue entre o realismo e o pluralismo de Bull. Somado à isso, Bull avança em colocar os Estados em sociedade, na qual a ordem é "a pattern (in the relations of human individuals or groups) that leads to a particular result, an arrangement of social life such that it promotes certain goals and values”. (BULL, 2002, p. 03) A sociedade anárquica de Hedley Bull, portanto, agrega os valores $^{8}$ como fatores constitutivos do padrão que formata a ordem internacional. Nesse sentido, a preocupação de Bull concentra-se na estrutura comum de regras e instituições, que haviam se desenvolvido na sociedade anárquica de Estados e que seriam responsáveis por prescrever os padrões de comportamento que sustentariam os objetivos básicos da vida social internacional.

A construção da ordem pluralista de Bull parece dar a enganosa impressão da facilidade de distinguir ordem como fato de ordem como valor. De um lado, falar em ordem como fato significa entendê-la como estabilidade, como um padrão regular de comportamento humano que contrasta com o caos, instabilidade ou perda de previsibilidade. Por outro lado, entender a ordem como valor requer o reconhecimento da existência de um tipo de padrão específico de propósitos para o qual os agentes daquela ordem tenham atribuído um

\footnotetext{
7 Justamente por essa razão, a presente pesquisa não endossa a inclusão da Escola Inglesa e, mais especificamente de Hedley Bull, no rol dos escritos realistas.

${ }^{8}$ Embora esses valores ainda apontem para uma direção muito mais minimalista e restritiva do que abrangente e ampla.
} 
significado comum. A ordem como valor envolve um grupo particular de metas, objetivos, ou valores que levem a um resultado particular.

Os objetivos primários da sociedade internacional são: 1) a preservação da própria sociedade de Estados; 2) a manutenção da independência dos Estados individuais e 3) a regulação, mas não eliminação - da guerra e violência entre os Estados e sociedades. Nesse sentido, não se poderia esperar que a cooperação entre Estados e as instituições internacionais pudessem prover uma paz estável e universal, mas somente mitigar os conflitos inevitáveis que surgiriam da multiplicidade de soberanias. A pergunta correta em relação à definição da ordem não é: "how might human beings create forms of international society or schemes of international cooperation that embodied all the aspirations for justice or which universalized some particular conception of the good society?”, mas sim: “how might states and other groups do each other the least possible harm and, in an age of total war and nuclear weapons, survive as a species?” (HURRELL, 2003, p. 26)

O lugar do Estado e de seu aparato soberano é central na ordem pluralista, que o define como uma estrutura que provê o pluralismo e protege a diversidade. O ponto de partida para essa concepção é a crença de que os indivíduos, nações e comunidades têm uma identidade que é promovida a partir do poder expressivo e protetor do Estado. Enquanto a soberania estatal provê a estrutura institucional básica, a autodeterminação, por sua vez, confere ainda mais poder político e significado moral à idéia de viver num mundo de Estados soberanos reunidos em uma sociedade internacional.

A promoção da coexistência e as possibilidades de limitação dos conflitos da sociedade internacional seriam promovidas pelas instituições da ordem pluralista, pautadas pelo Estado-Nacional. Construir meios moralmente significativos de coexistência, assim como limitar os conflitos num mundo onde não há consenso, em torno de formas mais elaboradas de cooperação, seria possível somente por meio da existência e preservação dessas instituições.

Essa concepção pessimista do pluralismo com relação às dificuldades políticas de sustentar (e promover) a cooperação, assim como do próprio poder político é responsável pela limitação dessa concepção de ordem, para a qual "all politics, but especially world politics, is the arena for struggles amongst differing social and political ideals, and the character of competition for power between these rival views - and the manner in which power is deployed - will remain a - but not necessarily the - central focus of enquiry" (HURRELL, 
2003, p. 27). Somado ao forte pessimismo quanto os usos, disputas e alcance do poder político, há um profundo ceticismo em relação aos argumentos que se referem à existência de consenso e valores compartilhados na sociedade internacional.

A ordem internacional pluralista, portanto, é resultado do objetivo que se tornou armadilha. O objetivo era o de tratar a realidade internacional tal como ela era e a armadilha é que o tratamento da realidade acabou por converter-se praticamente na transposição do que a realidade poderia ser. Frente à ausência de qualquer razão considerável para acreditar na viabilidade de transformar a sociedade internacional tal como ela é vista, entendê-la segundo o que já existe, isto é, a ordem internacional pluralista é considerada altamente significante do ponto de vista moral. Uma ordem minimalista e restrita, centrada no Estado nacional, é o que se tem e sob esse argumento pluralista, é o que se poderia e moralmente deveria ter.

A moralidade política para essa concepção de ordem está fortemente associada à prática da política, diretamente ligada aos jogos e estratégias do poder político. Desse modo, não se pode conceber princípios globais de justiça que sejam universais e que se apliquem à política externa. A moralidade política será sob essa perspectiva a arte de navegar com sucesso em mares revoltosos, onde a prudência é a virtude política suprema. Diante das conseqüências perversas e contingentes que caracterizam a ação política, caso haja princípios de justiça compartilhados, ainda irão envolver as questões de julgamento prudencial, adaptação pragmática, e trade-offs dolorosos entre objetivos conflitantes. (HURRELL, 2003, p. 29)

\subsection{O lugar e a definição da justiça na ordem internacional}

A reflexão de ordem, realizada acima, traz duas indicações importantes para o tratamento de ordem e justiça daqui para adiante: primeiro, a ordem a que se faz referência é pluralista e, segundo, se com relação à ordem é possível pensar as relações internacionais como de fato elas são; com relação à justiça caberá a tarefa de repensar como essa realidade internacional deveria ser. Em que termos, então, nos referimos à justiça?

\subsubsection{A justiça da ordem internacional pluralista do pós II Guerra Mundial}


"The UN is not an institution to which people should look if they want logic, consistency, clarity, and simplicity. The UN system as it has evolved since 1945 is a sprawling collection of states, conferences, and bureaucracies, and has been through many incarnations over time. (...) The UN is not an international actor in its own right. However, it has many important roles in international society, especially, so far as order/justice questions are concerned, as an agency which is involved in the development, articulation, and even sometimes implementation of international legal and political norms”. (ROBERTS, 2003, p. 51)

A Carta das Nações Unidas (CNU), assinada em 26 de junho de 1945 incorpora as preocupações da sociedade internacional com a ordem internacional, especialmente por meio da reafirmação do princípio da soberania estatal. O Artigo 2, em seus parágrafos (4) e (7), indica com clareza as normas mais difundidas e internacionalmente propaladas da Carta, ambas relacionadas à manutenção da ordem, por meio do compromisso com a nãointervenção e não-uso da força. São justamente essas normas que se referem diretamente ao nosso objeto de estudo - as intervenções humanitárias - pois são elas as responsáveis pela manutenção da ordem internacional.

Nesse sentido, a possibilidade de recorrer à intervenção e ao uso da força no plano internacional é aceita legitimamente pela Organização somente em duas situações: (1) legítima defesa, coletiva ou individual; e (2) nos casos em que o Conselho de Segurança da Organização tem "primary responsibility for the maintenance of international peace and security” (CARTA DA ONU, Artigo 24 (1), 1945). Porém, não é somente de preocupações com a ordem que a CNU é constituída. O documento também contém princípios e normas que exprimem preocupações com justiça. Logo no início da Carta, o preâmbulo apresenta a principal cláusula relacionada à justiça, que traz a seguinte determinação comum:

“(...) reafirmar a fé nos direitos fundamentais do homem, na dignidade e no valor do ser humano, na igualdade de direito dos homens e das mulheres, assim como das nações grandes e pequenas, e a estabelecer condições sob as quais a justiça e o respeito às obrigações decorrentes de tratados e de outras fontes do direito internacional possam ser mantidos, e a promover o progresso social e melhores condições de vida dentro de uma liberdade ampla. E para esses fins (...) empregar um mecanismo internacional para a promoção de progresso econômico e social de todos os povos”. (CARTA DA ONU, 1945)

Igualmente, no Capítulo I, dos Propósitos, a Carta contém comprometimentos com a justiça, expostos em cada um desses três parágrafos: 
"1. Manter a paz e a segurança internacionais e, para esse fim: tomar, coletivamente, medidas efetivas para evitar ameaças à paz e reprimir os atos de agressão ou outra qualquer ruptura da paz e chegar, por meios pacíficos e de conformidade com os princípios da justiça e do direito internacional, a um ajuste ou solução das controvérsias ou situações internacionais que possam levar a uma perturbação da paz; 2. Desenvolver relações amistosas entre as nações, baseadas no respeito ao princípio de igualdade de direitos e de autodeterminação dos povos, e tomar outras medidas apropriadas ao fortalecimento da paz universal; 3. Conseguir uma cooperação internacional para resolver os problemas internacionais de caráter econômico, social, cultural ou humanitário, e para promover e estimular o respeito aos direitos humanos e às liberdades fundamentais para todos, sem distinção de raça, sexo, língua ou religião”. (CAPÍTULO 1, CARTA DA ONU, 1945)

Além desses parágrafos, a CNU apresenta ao longo de seu texto, nos artigos 13, 55, 56, 62, 68 e 76, comprometimentos específicos para ação com relação aos direitos humanos. (ROBERTS, 2003, p. 54) De forma semelhante, as atribuições e competências dos dois principais órgãos da ONU também parecem refletir essa dualidade entre ordem e justiça.

Essa inclusão da linguagem dos direitos humanos e da justiça na CNU que tem sido freqüentemente atribuída aos esforços norte-americanos, foi de fato o resultado da pressão de muitos Estados, incluindo até a União Soviética, que por sua própria visão, ou no mínimo retórica, defenderam a criação de um sistema de justiça global, além das fronteiras dos Estados soberanos existentes. O contexto posterior ao término da II Guerra Mundial foi determinante para esse processo de extensiva atenção à justiça nos artigos e atribuições da CNU. (ROBERTS, 2003, p.)

Essa inclusão foi apropriada ao período peculiar da história mundial de bipolaridade que se seguiu ao final do conflito bélico mundial. A polarização da Guerra Fria, ao mesmo tempo em que paralisou qualquer atuação autônoma da ONU, permitiu que a Organização fosse criada sob alguns compromissos: (1) compromisso de adesão e defesa aberta das ideologias anti-coloniais, e defesa pela extinção dos impérios coloniais europeus; (2) apoio (retórico) à proposição de que o sistema de Estados era insatisfatório e precisava ser reformado, embora esse fosse dificilmente observado na prática política; e (3) aceitação da retórica dos direitos humanos. (ROBERTS, 2003, p.55)

Após elencar esses fatores como constituintes de um período peculiar que justificou a inclusão das preocupações com justiça na CNU, Roberts afirma que, naquele contexto, a Carta que tivesse simplesmente estabelecido um clube de Estados existentes, sem referência às questões de justiça nunca poderia ter sido acordada, nem sobrevivido. (ROBERTS, 2003, p. 55) A exemplo da Liga das Nações, que teve um envolvimento limitado em certos assuntos relacionados à justiça, como a proibição da escravidão. “The League’s failure to be associated 
with justice, as well as its incapacity to maintain order, helps to explain, its decline into insignificance during the 1930s”. (ROBERTS, 2003, p. 49)

O grande tema que parece ser o mais representativo do comprometimento da Organização com a justiça é o anti-colonialismo. As provisões da Carta que conciliaram o processo de descolonização européia foram opacas, dada a discordância entre os Estados envolvidos no desenho da Carta, alguns dos quais firmemente anti-coloniais, enquanto outros, como Inglaterra e França, tentavam permanecer com partes de seus territórios extra-europeus. A palavra descolonização, por exemplo, não foi usada, mas a ênfase da Carta na igualdade soberana dos Estados e suas provisões no que se refere aos territórios sem governo próprio (Capítulo XI) e do sistema internacional de tutela (Capítulo XII) continham a suposição implícita de que os dias do colonialismo europeu estavam próximos do fim. A frase cautelosa “direitos iguais e autodeterminação dos povos” usada no Artigo 1(2), também pode ser vista como uma legitimação do princípio de descolonização. (ROBERTS, 2003, p. 57)

Dessa forma, mesmo que as provisões da Carta tenham sido cautelosas, elas demonstram que as atribuições da ONU estavam associadas ao mais importante processo das relações internacionais desde a II Guerra Mundial, ou seja, a divisão dos impérios coloniais em Estados soberanos. Considerando que os esforços pelo fim dos impérios coloniais resultaram na criação de inúmeros novos Estados, adensando o número de membros da própria Organização, a atuação desses Estados recém-constituídos foi determinante para a inclusão das preocupações com justiça, principalmente pelo temor de que as grandes potências conduzissem uma política de conciliação no pós-II Guerra em detrimento deles, como havia sido o Tratado de Munique em 1938.

No argumento de Roberts (2003, p. 54), a atuação desses novos membros assinala um elemento-chave da concepção de justiça da ONU: o respeito aos direitos soberanos desses Estados recém-constituídos. Tal elemento foi incorporado no Artigo 2 (4), que estabelece o princípio não-intervencionista básico da Organização: “Todos os Membros deverão evitar em suas relações internacionais a ameaça ou o uso da força contra a integridade territorial ou a dependência política de qualquer Estado, ou qualquer outra ação incompatível com os Propósitos das Nações Unidas”. (CARTA DA ONU, 1945) Dessa maneira, “The nonintervention rule was widely seen as fundamental and was presented as reflecting the demands of justice as well as of order”. (ROBERTS, 2003, p. 61)

Em 1960, com o processo de descolonização ganhando ritmo, a Assembléia Geral aprovou a Declaração sobre a Concessão da Independência aos Países e Povos Coloniais, que proclamou em seu primeiro artigo substantivo: "A sujeição dos povos a uma subjugação, 
dominação e exploração constitui uma negação dos direitos humanos fundamentais, é contrária à Carta das Nações Unidas e compromete a causa da paz e da cooperação mundial”. Segundo Roberts (2003, p. 57), essa Declaração teria sido a primeira de uma série de declarações interpretando as provisões da CNU sobre o relacionamento entre ordem e justiça.

O que se pode perceber é que a justiça da Carta da ONU é uma justiça para os Estados e dos Estados soberanos, ou seja, é uma justiça forjada na ordem pluralista, que convive e reforça essa ordem. Não há conflito entre ambas, porque é a ordem dos Estados comprometendo-se com a justiça dos Estados. Os elementos de justiça dessa ordem, que são extraídos dessa breve análise da CNU - como o compromisso com soberania dos Estados recém-constituídos, com a garantia de respeito à independência e a autodeterminação dos mesmos, com a retórica da preservação dos direitos humanos internamente - demonstram que o Estado é o refencial dessa idéia de justiça, no qual os princípios de justiça são garantidos e assegurados pelo Estado soberano. "If order can be projected 'outside', justice continues to belong 'inside'. The imperative of justice remains circumscribed by 'national' boundaries, be it within the traditional nation-state (...)”. (NICOLAIDIS; LACROIX, 2003, p. 132)

A vertente pluralista da Escola Inglesa, assim como a solidarista, não define justiça. Essa ausência deve-se à formulação dos primeiros escritos da Escola Inglesa, referenciada pela obra A Sociedade Anárquica de Hedley Bull, que não tinha a justiça dentre suas principais preocupações. A intenção clara e objetiva, definida naquele momento, era pensar a ordem. Isso não significa dizer que as preocupações pluralistas de Bull, que inauguraram a reflexão sobre a ordem no pensamento da Escola Inglesa, não possuem uma visão de ética e justiça.

Segundo a concepção de ordem de Bull, na medida em que certos objetivos foram estabelecidos a fim de atingir um resultado comum para todos os membros da sociedade internacional, buscar a realização desses objetivos definiu-se como uma ação correta e justa. Portanto, seguir a ordem internacional pluralista, isto é, respeitar a soberania estatal, sem intervir, sem recorrer à força e permitindo a autodeterminação era considerado o justo.

O problema é que, nessa perspectiva, o valor da ordem não é colocado dentro de uma estrutura ou explicação ética geral que permita posicioná-lo frente a outros valores, como a justiça. Conseqüentemente, essa formulação de ordem não indica quais as possibilidades de resolver os desacordos entre ordem e justiça, ou mesmo quando os valores dessa ordem internacional minimalista poderiam ser ultrapassados em nome dos interesses da justiça. 
Apesar disso, há nessa formulação uma ressalva consequencialista: as questões de justiça só poderiam ser significativamente endereçadas depois que alguma quantidade mínima de sociedade e ordem internacional seja construída, numa clara subordinação da justiça à ordem. "The survival and promotion of the states system is not only the basic underlying condition of order but also of the pursuit of justice. If justice is attainable only inside state-like borders, then both international order and justice are predicated on the preservation of norms of sovereignty and non-intervention”. (NICOLAIDIS; LACROIX, 2003, p. 132)

A exigência de que uma quantidade mínima de sociedade exista é o mesmo que requerer a satisfação da ordem antes da realização de qualquer outro valor. Segundo essa perspectiva, "order in social life is desirable because it is the condition of the realization of other values...International order, or order within the society of states, is the condition of justice or equality among states and nations”. (HURRELL, 2003, p. 26) O que corresponde à formulação de Walzer de sociedade primeiro, normas compartilhadas depois. "There cannot be a just society until there is a society; and the adjective just doesn't determine, it only modifies, the substantive life of the societies it describes”. (WALZER, 1983, p. 313)

O problema é que as convicções compartilhadas são o principal elemento de formação de uma sociedade em qualquer nível. Portanto, os entendimentos de justiça constituem ou determinam as sociedades e a ordem, e não necessariamente são criados após a constituição destas. Assim, entendimentos e sociedades nascem juntos. "The agreements about what is just, fair, important, and so on constitute the fabric of the society - the shared beliefs (and aspirations and fears) are the skeleton around which the society forms”. (SHUE, 2004, p. 25)

Dessa maneira, o entendimento de justiça que nasceu junto com a ordem pluralista constitui uma justiça na qual as preocupações são guiadas pelo pluralismo, ou seja, pelos objetivos de preservar a sociedade de Estados, de manter a independência dos Estados individuais, e regular as relações conflituosas e o uso da força, em torno da moralidade estatal. Portanto, o consenso que tornou peculiar o período da Guerra Fria esteve baseado no entendimento de que o justo era comportar-se para a manutenção daquela ordem minimalista e centrada no Estado soberano. A inclusão da retórica dos direitos humanos na CNU, por exemplo, representava a reafirmação da função primária do Estado soberano de proteger os seus cidadãos, garantindo seus direitos básicos no interior das fronteiras nacionais.

Segundo esse paradigma estatista, a ordem pluralista não abdicou de uma agenda de justiça global. Ao contrário, há justiça, mas sua existência é circunscrita as comunidades 
políticas, no interior das quais é possível imaginar uma abordagem universal da justiça, não aquela tão abstrata e imparcial para a qual não é possível obter uma solidariedade significativa e divisão da riqueza. (NICOLAIDIS; LACROIX, 2003, p. 133) O ethos pode ser transformado em demos somente em nível nacional, assim como esse é o único nível onde os valores de liberdade, responsabilidade civil e justiça política adquirem verdadeiro significado. É de fato essa construção de dois gumes de ethos e demos que leva a internacionalização subjetiva da idéia de 'fronteiras' e à noção das pessoas do que significa estar no mundo, através de um pertencimento que excluí. (NICOLAIDIS; LACROIX, 2003, p. 130)

\subsubsection{Desafios à ordem internacional pluralista: impactos e transformações do fim do século $X X$}

Três grandes movimentos do fim do século XX, nomeadamente o fim da Guerra Fria, o processo de globalização e a interdependência, demonstraram a necessidade de repensar as preocupações com a justiça."The ending of the Cold War led to a renewed interest in the promotion of a just world order because of the presumed collapse of geopolitical and ideological confrontation, and the perception that certain set of values concerning the wellbeing of human beings were now more widely shared". (FOOT, 2003, p. 01)

O processo de globalização, por sua vez, aprofundou não só o senso de interdependência material, como também de idéias, concedendo poder a um novo grupo de vozes, que deixaram de depender da voz uníssona do Estado nacional para serem ouvidas na esfera internacional. A interdependência, sentida na percepção de que todos os indivíduos, grupos, nações e Estados nacionais dividem um único mundo e, portanto, compartilham uma série de novos e complexos desafios, permitiu que se desenvolvesse a percepção de que as soluções sustentáveis e efetivas para tais desafios só poderiam ser alcançadas a partir de uma preocupação compartilhada por justiça. (FOOT, 2003, p. 01)

O desenvolvimento dos direitos humanos pode ser tomado como um dos principais exemplos de uma incorporação das preocupações relacionadas à justiça em um formato distinto do período do pós II Guerra Mundial e Guerra Fria. Os desenvolvimentos do sistema de garantia e proteção dos direitos humanos desde a criação da ONU, com a Declaração Universal dos Direitos Humanos (1948); a Convenção contra o de Genocídio (1948); os Pactos de Direitos Econômicos, Sociais e Culturais e de Direitos Civis e Políticos (1966, com entrada em vigor em 1976); Convenção Relativa ao Estatuto dos Refugiados (1951); 
Convenção para a Eliminação de Todas as Formas de Discriminação Racial (1965); Convenção Internacional Sobre a Eliminação de Todas as Formas de Discriminação Contra a Mulhere (1979); Convenção contra a Tortura e outros Tratamentos ou Penas Cruéis, Desumanas e Degradantes (1984); e Convenção sobre os Direitos da Criança (1989), refletiram passos importantes no comprometimento internacional com a proteção desses direitos no interior dos Estados soberanos.

"These agreements had momentous implications, not just for the relations between citizen and state but also for the conduct of international relations. For good or ill, they strongly reinforced the view that a government's treatment of its citizens was a matter of legitimate international concern”. (ROBERTS, 2003, p. 63) Esses acordos também forneceram mecanismos onde as questões de direitos humanos poderiam ser perseguidas.

A globalização e a interdependência promoveram, segundo Hurrell, uma verdadeira mudança estrutural na sociedade internacional, que envolveu a criação de regras e instituições profundamente invasivas no que se refere à organização doméstica das diferentes sociedades. O compromisso e envolvimento com políticas de desenvolvimento econômico, proteção ambiental, direitos humanos, resolução de crises de refugiados, combate às drogas, ou luta contra o terrorismo não mais competiam somente ao âmbito interno de um só Estado, mesmo que este fosse uma superpotência. Os temas e agendas de política interna e externa contemporâneos passaram a demandar a existência da possibilidade de escrutínio no que antes pertencia somente à prerrogativa estatal soberana, além da interação dos atores internacionais e transnacionais, não mais restritos somente aos governos e atores centrais. (HURRELL, 2003, p. 33)

A ONU exemplifica muito bem essa séria de grandes transformações do fim do século XX. Da negociação de sua Carta constitutiva adiante, os interesses e ideologias dos principais poderes, incluindo os membros permanentes do CS, formataram as preocupações da Organização com um amplo alcance das questões conectadas com a justiça, inlcuindo àquelas que as relações dos cidadãos com o Estado. Interesse e justiça não têm habitado categorias separadas. No entanto, de 1945 adiante, as articulações dos princípios de ordem e justiça da ONU, incluindo o campo dos direitos humanos, não tem sido resultado da dominância por um único poder hegemônico, mas o produto de uma difícil barganha entre Estados com diferentes pontos de vista e tradições. (ROBERTS, 2003, p. 76) Os países em desenvolvimento foram os defensores e criadores de normas, via Assembléia Geral, em deslegitimar o colonialismo, 
criminalizar o apartheid e legitimar os movimentos armados de liberação nacional. (THAKUR, 2006, p. 281)

Sérios esforços tem sido feitos para criar elementos de um consenso global sobre certas normas de justiça e mesmo sobre sua implementação. A ONU está agora fortemente associada com uma visão que uma paz duradoura, entre e dentro os Estados, deveria ser baseada nas idéias de justiça. "The question for member states is not whether the UN should be involved in justice-related issues but which ones should be emphasized, how they should be pursued, and how clashes over them should be mitigated”. (ROBERTS, 2003, p. 79)

\subsubsection{Novos referenciais para a justiça? A soberania como responsabilidade de proteger o indivíduo}

O contexto de grandes modificações que abalou a ordem pluralista afetou substantivamente a percepção do que chamamos anteriormente de uma justiça forjada na ordem pluralista, baseada no argumento de que a função de promover a justiça estava restrita ao Estado nacional e às suas fronteiras. A progressiva porosidade das fronteiras estatais contribuiu para a constatação da incapacidade dos Estados nacionais de lidar com a complexidade dos desafios transnacionais e multifacetados.

Essas transformações que alteraram a capacidade e o alcance das ações estatais exigiram novos compromissos normativos, especialmente com relação aos direitos humanos, A questão, no entanto, é a distância entre a observância dos compromissos normativos para com os direitos humanos ao redor do globo e os instrumentos de coerção existentes na sociedade internacional para a proteção e garantia dos mesmos.

Foi justamente nesse contexto que o recurso à intervenção pela força apareceu como alternativa para a coerção às normas humanitárias globais. Mas, não sem custos, já essa alternativa de imposição da justiça se opõe à ordem, baseada no princípio de soberania e nas normas da não-intervenção e não-uso da força. Nesse novo contexto normativo, alguns limites foram impostos aos Estados soberanos com relação ao tratamento de seus cidadãos, assim como deveres e responsabilidade para com os estrangeiros que estivessem sofrendo por graves violações de seus direitos humanos básicos, sejam em situações de limpeza étnica, assassinatos em massa ou genocídio. 
A idéia de limitação e de transformação da soberania enquanto autoridade para uma soberania definada pela responsabilidade será analisada a seguir. Essa proposição compreende a substância teórica que fundamenta a segunda parte dessa seção, na qual apresentaremos a proposta prática de Wheeler com relação a legitimidade das intervenções humanitárias.

\section{"Soberania como responsabilidade": o indivíduo como refencial das intervenções humanitárias}

A proposta de articulação entre as prerrogativas externas da soberania estatal e a justificativa moral, desenvolvida por Henry Shue, no texto Limiting Sovereignty (2003), parte da premissa da redefinição do direito soberano de ser livre para fazer o que é moralmente condenável. ${ }^{9}$ Essa mudança no escopo do exercício da soberania requer dois passos, segundo o autor: no primeiro é preciso que algo seja considerado tão errado que mesmo os soberanos não se entenderão livres para fazê-lo; o segundo passo é que essa idéia deve ser entendida por todos os soberanos como fora do escopo da soberania. O que significa que os soberanos não deverão, de acordo com essa nova norma da soberania, cometer esse no futuro. (SHUE, 2004, p. 12)

Tomemos um exemplo: a limpeza étnica seria considerada tão errada pelos Estados que nem mesmo eles com a liberdade que sua soberania confere se sentiram livres para realizar. Num segundo momento, todos os Estados concordariam que a limpeza étnica está generalizadamente fora do escopo da soberania. Portanto, os Estados, seguindo essa nova norma, não realizaram mais limpeza étnica no futuro, abolindo essa prática da lista de erros que os Estados soberanos são livres para cometer.

Um aspecto muito importante desse processo de limitação da soberania é que ele parte do princípio de que uma mudança de norma pode preceder, ao invés de ser base para, uma demanda para a mudança de comportamento e, ainda, essa mudança de norma pode ser baseada, no mínimo em parte, em considerações morais. "Morality can require a change in the specification of a role, and the change in the specification of the role can then require a

\footnotetext{
${ }^{9}$ KRATOCHWIL, Friedrich. 'Sovereignty as Dominium: Is there a Right of Humanitarian Intervention?'.In: GENE, Lyons; MASTANDUNO (eds.). Beyond Westphalia? State Sovereignty and International Intervention. Baltimore: Johns Hopkins University Press, 1995.
} 
change in behavior. The moral considerations influence behavior indirectly by way of their effect on the role. Morality's work is indirect but not irrelevant”. (SHUE, 2004, p. 12)

A idéia de limitação da soberania remonta à como a soberania foi pensada originalmente. Shue lembra que quando o Estado foi concebido como autoridade moral e legal, a soberania não era (e não é) uma matéria sobre a qual cada Estado tinha (e tem) arbítrio irrevogável e total. A norma da não-intervenção surgiu justamente como exemplo dessa limitação, pois a não-intervenção protege a soberania estatal interna limitando a soberania externa dos outros Estados. (VINCENT, 1974, apud SHUE, 2004, p. 15) Portanto, ao mesmo tempo, que a não-intervenção protege o princípio da soberania, a soberania é limitada pela não-intervenção.

Além disso, soberania limitada é resultado de um direito à soberania e direitos são baseados em normas limitadoras e não na anarquia. É desse modo que Shue (2004, p. 14) refuta o argumento realista de que os Estados, por serem soberanos, são livres para fazer mesmo o que for moralmente condenável. Nesse sentido, os Estados poderiam fazer guerra ou agir sem qualquer limitação dentro de uma anarquia genuína, mas se os Estados têm o direito de fazer alguma coisa, incluindo de ir à guerra, eles estão numa situação parcialmente governada por regras, não numa completa anarquia.

Bull chama de "unqualified prerogative" quando existe apenas a liberdade, a instância de "no-duty-not-to", ou seja, quando não há dever de não fazer alguma coisa, o que é inteiramente compatível com a total ausência de obrigações de todos os lados simplesmente porque não há regras, e então não há sociedade entre os Estados. O direito há algo ou alguma coisa, ao contrário, é um caso de “duty-not-to-interfere”, ou seja, todos têm o dever de não interferir com a prerrogativa que esse direito confere. (BULL, 1966, apud SHUE, 2004, p. 15)

O direito a uma liberdade só existe somente quando os outros são obrigados a respeitar esse direito. Quando um Estado tem um direito a fazer qualquer coisa é porque existe uma sociedade de Estados no sentido de que suas relações são, neste grau, governada por regras. Primeiro é preciso haver normas compartilhadas, para depois os direitos existirem. Do contrário, até que regras comuns surjam, nenhum direito existe. "Sovereignty is limited because the duties that are constitutive of the right, and without there can be no right, constrain the activity of every sovereign belonging to international society”. (SHUE, 2004, p. 
Quando um agente tem um direito, a conduta de qualquer outro agente é limitada. Se todos têm o direito, a conduta de todos é limitada. Por isso, enquanto há a atribuição de um direito à soberania a qualquer jogador na arena, não faz sentido descrever a arena internacional como anarquia, ou seja, como um "free-for-all” completo no qual os resultados são inteiramente determinados pela distribuição de poder. (SHUE, 2004, p. 16)

A segunda premissa de Shue (2004, p. 16) é de que o direito à soberania é um direito limitado de cometer erros, isto é, um direito de cometer alguns erros, mas não outros. Mas, quais seriam esses erros? E por que eles limitariam a soberania? Existem dois tipos de erros: aqueles que os Estados têm a liberdade de cometer e aqueles que são proibidos mesmo para os Estados. O genocídio é um dos erros dessa segunda categoria, pois esse processo abjeto infringe direitos individuais fundamentais, como o direito de não ser morto. Os limites específicos sobre a soberania estatal são ditados justamente pela natureza dos direitos individuais fundamentais.

Todo o sistema efetivo de direitos precisa incluir algumas “default duties”, ou seja, obrigações que constituem uma segunda linha de defesa que requer que Y tome uma atitude em direção a uma determinada ruptura que $X$, primeira linha de defesa, tinha a obrigação primária de impedir que acontecesse. A questão está, contudo, em estabelecer as "default duties”, pois há casos em que o direito em questão é importante o suficiente para que qualquer um tenha a obrigação de não privar ninguém dele, mas não tão importante a ponto de que quando alguém viola essa obrigação de não privação, outra categoria de pessoas assume a “default duty” para prevenir ou punir essa violação. (SHUE, 2004, p. 17)

Quando declaramos que algum interesse será protegido por um direito básico ou fundamental significa que o interesse em questão é tão vital ou valioso, ou ambos, que recursos consideráveis deveriam ser utilizados para garantir, na medida do que é humanamente possível, que as pessoas fossem, no pior dos casos, só raramente privadas dele. "If the primary duty regarding the vital interest at the core of a basic right is not performed, a secondary, or default, duty must immediately take hold”. (SHUE, 2004, p. 17)

O argumento das “default duties” de Henry Shue (2004) cabe tanto à formulação solidarista de Nicholas Wheeler (2000), quanto à proposta do documento "Responsabilidade de Proteger”. Nos casos que justificam uma intervenção humanitária, como já foi anteriormente, os direitos básicos individuais não estão sendo respeitados, demonstrando uma falha evidente no papel do Estado nacional, de cumprir com sua obrigação primária, em relação a tais direitos. Portanto, é necessário que a comunidade internacional exerça sua 
responsabilidade de garantir o direito básico o Estado nacional por alguma razão deixou de garantir, agindo na segunda linha de defesa de um sistema efetivo de direitos.

"If all the rest of us (still undifferentiated) actually do nothing to define and assign default duties for the case in which state does not protect its own people against genocide (...) then we genuinely are assigning the vital interests and basic rights of non-compatriots zero weight in our calculations about how to organize the planet, specifically how to understand sovereignty”. (SHUE, 2004, p. 21)

O relatório "Responsabilidade de Proteger"10 da Comissão Internacional sobre Intervenção e Soberania Estatal (CIISE) revisou o conceito de soberania propondo justamente uma substituição da idéia tradicional de "soberania como autoridade" (controle sobre o território) para a idéia de "soberania como responsabilidade” (respeito por um padrão mínimo de direitos humanos). O conceito de "soberania como responsabilidade” se baseou na "double belief that sovereignty of a state has an accompanying responsibility on the part of that state; and that if the state defaults on the responsibility to protect its citizens, the fall-back responsibility to do so must be assumed and honoured by the international community”.(THAKUR, 2006, p. 251)

A proposta da CIISE de uma nova conceitualização da soberania reconhece primariamente que a responsabilidade pela proteção dos indivíduos e de seus direitos básicos é primeiramente do Estado e, que somente se o Estado não for capaz ou estiver disposto a cumprir com essa responsabilidade, ou ainda seja o perpetrador das violações desses direitos, essa responsabilidade se torna dos outros Estados. O lócus dessa responsabilidade residual, portanto, está na comunidade de Estados.

A reconceitualização da soberania como responsabilidade tem um triplo significado: 1) implica que a autoridade estatal é responsável pelas funções de proteger a segurança e a vida dos cidadãos e a promoção de seu bem-estar; 2) sugere que as autoridades políticas nacionais são responsáveis pelos cidadãos internamente e a comunidade internacional, por meio da ONU, externamente; 3) significa que os agentes dos Estados são responsáveis por suas ações, isto é, que eles são responsabilizáveis por seus atos de ação e omissão. “There is a redefinition from sovereignty as right of exclusivity to sovereignty as responsibility in both internal functions and external duties”. (THAKUR, 2006, p. 256)

\footnotetext{
${ }^{10}$ Informações mais detalhadas a respeito do relatório "Responsabilidade de Proteger" e da Comissão sobre Intervenção e Soberania Estatal (CIISE) serão apresentadas na seção 1.2.5. Três tipos de responsabilidades: dialogando com a proposta prática de Saving Strangers a seguir.
} 


\subsubsection{Estabelecendo critérios para a legitimidade das intervenções humanitárias: a proposta solidarista de reconciliação de ordem e justiça}

O pressuposto da proposta solidarista, desenvolvida na obra Saving Strangers (2000), de Nicholas Wheeler, é que mesmo diante de uma mudança considerável no contexto normativo em relação às intervenções humanitárias, essas intervenções ainda permaneciam, em seu aspecto prático, como ponto de dissenso e controvérsia. Portanto, sua intenção foi desenvolver e propor requisitos que uma vez observados confeririam legitimidade à prática das intervenções humanitárias, mesmo que elas não fossem consideradas legais, do ponto de vista jurídico internacional.

Nessa seção, os requisitos de legitimidade do solidarista Wheeler (2000) serão apresentados e inicialmente discutidos, no entanto, os argumentos solidaristas do autor serão aprofundados ao longo de todo o trabalho. O argumento de um novo contexto normativo, por exemplo, guiará as análises do capítulo II e III, por meio da comparação entre as intervenções ocorridas no período da Guerra Fria (Índia, 1971; Vietnã, 1979; Tanzânia, 1979) e as intervenções humanitárias da década de 1990 (Somália, 1992; Ruanda, 1994; e Kosovo, 1998).

O argumento que dá sentido à proposição prática de legitimidade das intervenções humanitárias está relacionado à tese de Wheeler de que o argumento humanitário que não era aceito como base legítima para o uso da força nos anos 70 passou a ser considerado legítimo a partir de um novo contexto normativo desenvolvido, no interior das Nações Unidas, nos anos 1990. Apesar disso, o que ainda permanece controverso é a legitimidade da prática das intervenções humanitárias sem a autorização expressa do CS da ONU, ou seja, nos casos de intervenção humanitária unilateral, realizada por Estados ou por organizações regionais.

Isso justifica, portanto, a preocupação de Wheeler (2000) em torno da formulação de um grupo de requisitos que possam, por meio de critérios práticos, conferir legitimidade a uma intervenção humanitária, mesmo que ela não tenha sido aprovada e, portanto, legitimada pelo CS da ONU. O caso controverso da intervenção humanitária na Somália (1992), o caso de inação frente ao genocídio em Ruanda (1994) e a intervenção da OTAN no Kosovo (1998), sem autorização expressa do CS da ONU inspiraram e motivaram essa formulação solidarista, principalmente no sentido de que a autorização do CS não fosse considerada um critério decisivo para a atribuição de legitimidade a uma determinada intervenção humanitária. 
A proposta prática de Wheeler inicia-se com um grupo de quatro critérios mínimos e essenciais que definirão as condições para que uma dada intervenção possa ser considerada legitimamente humanitária. Provenientes da tradição da guerra justa, os requisitos mínimos são os seguintes: 1) Emergência humanitária suprema; 2) Requisito de Necessidade, isto é, o uso da força deve ser o último recurso; 3) Requisito de Proporcionalidade, ou seja, o uso da força deve ser proporcional ao dano humanitário que se pretende prevenir ou cessar; e 4) Resultado humanitário positivo. (WHEELER, 2000, p. 33)

O requisito de que a situação seja uma emergência humanitária suprema acontece nas situações extraordinárias “(...) where civilians in another state are in imminent danger of losing their life or facing appalling hardship, and where indigenous forcer cannot be relied upon to end these violations of human rights” (WHEELER, 2000, p. 50). Nesse caso, as violações que “chocam a consciência da humanidade” não podem ser impedidas senão pela alternativa da intervenção externa. Nas palavras Walzer, uma emergência humanitária suprema: "state leaders find themselves confronted with these situations only in rare occasions. But, when they do, they are confronted with the ultimate choice between realist and solidarist conceptions of moral responsibility in statescraft”. (WALZER, 1978, p. 25168)

Wheeler não estabelece uma definição objetiva do que seria uma emergência humanitária suprema, mas faz referência direta ao caso de genocídio e de falência do Estado que leve à fome a ao colapso da lei e da ordem, como a situação na Somália em 1992. Já a partir dessa definição do primeiro requisito, é possível iniciar uma reflexão sobre a justiça na percepção solidarista. A priori a justiça que está relacionada às intervenções humanitárias está justamente relacionada a essa primeira condição da causa justa, ou como Wheeler prefere denominar, da emergência humanitária suprema. É essa condição que se refere ao indivíduo e à garantia de seus direitos fundamentais que não estão sendo por alguma razão respeitados ou protegidos por seu Estado soberano. (WHEELER, 2000, p. 50)

A idéia de justiça na intervenção humanitária que se pode extrair desse primeiro requisito está intimamente relacionada à uma concepção do mínimo essencial referindo-se em específico aos seguintes direitos: direito à vida (aos meios de subsistência e segurança) ${ }^{11}$; à

\footnotetext{
${ }^{11} \mathrm{O}$ direito de subsistência refere-se às condições básicas necessárias à sobrevivência, tendo o abrigo como primeira condição, seguida de acesso a alimento e água. A interpretação de Henry Shue em Basic Rights: Substance, Affluence, and U.S. Foreign Policy (1980) e R. J. Vincent em Human Rights and International Relations (1986) com relação à subsistência como direito humano básico é partilhada por John Rawls (2003, p. 85) e também pela presente pesquisa.
} 
liberdade (à liberação de escravidão, servidão e ocupação forçada); direito de ir e vir; direito à integridade física; direito à liberdade de consciência; direito de não ser torturado; direito de não sofrer genocídio; direito de não sofrer limpeza étnica e direito à propriedade (propriedade pessoal) $)^{12}$.

Segundo Shue, no mínimo os direitos básicos de todos devem ser assegurados. "If some people must be left without protection against genocidal massacre, the basic right not to be killed is not universally effective”. Algumas pessoas não têm o esse direito como universalmente efetivo, e isso não significa que esses direitos sejam garantidos infalivelmente, mas que sejam simplesmente assegurados num patamar razoável para todos. (SHUE, 2004, p. 22)

Esta lista mínima de direitos é que torna possível falar em justiça no contexto das intervenções humanitárias, partindo do princípio de que sem a observância desses direitos básicos não há justiça. Realizar intervenções humanitárias é, nesse sentido, assegurar que tais direitos básicos que estão sendo violados pela unidade estatal soberana, responsável por defendê-los; ou, que não estão sendo assegurados devido à incapacidade ou falência do Estado, sejam garantidos.

"If all the rest of us (still undifferentiated) actually do nothing to define and assign default duties for the case in which state does not protect its own people against genocide (...) then we genuinely are assigning the vital interests and basic rights of non-compatriots zero weight in our calculations about how to organize the planet, specifically how to understand sovereignty”. (SHUE, 2004, p. 21)

Os segundo e terceiro requisitos são bastante relacionados, já que ambos referem-se à quando e como a força deve ser aplicada. O requisito da necessidade está diretamente relacionado com a tentativa de reconciliar o imperativo moral de uma ação rápida, que impeça um aumento das violações graves, com a condição da guerra justa, de que a força deve ser sempre o último recurso.

Nigel Rodley define esse critério de necessidade como uma condição onde nenhuma aplicação de força reduzida seria suficiente para cessar as violações dos direitos humanos em questão. Do mesmo modo, o autor define o critério de proporcionalidade como a

\footnotetext{
${ }^{12}$ Essa lista de direitos humanos mínimos foi inspirada na lista de direitos humanos de Rawls, a qual teve por fonte a Declaração Universal de Direitos Humanos de 1948, mais especificamente os direitos do intervalo entre o Artigo III e XVIII que, segundo Rawls, em nota de O Direito dos Povos (2004, p. 104) podem ser colocados sob a denominação de direitos humanos propriamente ditos. Alguns dos direitos também dizem respeito ao que é considerada uma segunda classe de direitos humanos, que são implicações óbvias da primeira classe de direitos. A segunda classe de direitos é proveniente de casos extremos descritos em convenções especiais, como a Convenção contra o Genocídio (1948) e sobre o ‘apartheid’ (1973).
} 
compatibilidade entre a gravidade e a extensão das violações que estão ocorrendo e um cálculo razoável de perda de vidas, destruição de propriedade e gasto de recursos. (RODLEY apud WHEELER, 2003, p. 35)

O último requisito para considerar uma intervenção humanitária como legítima requer que o resultado obtido possa ser considerado como um resultado humanitário positivo, que o autor apresenta em duas perspectivas, a de curto e longo-prazo. A primeira refere-se ao sucesso da intervenção em extinguir de imediato uma situação de emergência humanitária suprema. Já a perspectiva de longo-prazo é definida a partir do quanto uma intervenção foi dirigida as razões geradoras dos abusos dos direitos humanos que esta procurou combater.

Além dos quatro critérios iniciais apresentados, Wheeler (2000) estabelece critérios adicionais que uma vez presentes reforçariam a legitimidade de uma intervenção humanitária. O primeiro deles se refere à justificativa da intervenção em termos humanitários. Apesar do argumento realista de que os Estados abusam das razões humanitárias para atingir objetivos próprios, o autor acredita na utilização do humanitário como justificativa por duas razões principais: a primeira é porque o abuso com relação à justificativa humanitária que serviria para encobrir interesses próprios e egoístas só será de fato uma objeção à intervenção humanitária se os motivos baseados nesses interesses escusos não permitirem que os propósitos humanitários sejam alcançados.

A segunda razão para que as justificativas sejam consideradas como um critério adicional de legitimidade é que crítica realista aos motivos encobertos simplesmente ignora a possibilidade tanto de que a justificativa e a motivação sejam correspondentes em sua matriz humanitária, quanto o reconhecimento dos líderes dos Estados com relação à responsabilidade moral dos mesmos em defender os direitos humanos onde quer que estes estejam sendo violados, sem as restrições de nacionalidade. Além disso, o argumento realista subestima o quanto os atores tornam-se envolvidos por suas justificativas, já que uma vez que as justificativas humanitárias tenham sido mobilizadas por um Estado, um padrão normativo no qual esse Estado poderá julgar e ser “julgado” em suas ações subseqüentes é estabelecido.

O problema, portanto, não seria a discrepância entre as justificativas e as motivações, porque mesmo uma intervenção em que a justificativa e as motivações sejam humanitárias, o resultado atingido pode não ser bem sucedido do ponto de vista humanitário. Nesse sentido, o sucesso de uma intervenção está mais relacionado aos meios utilizados do que propriamente à dissonância entre justificativa e motivação para intervir. 
O outro critério adicional está ligado à questão da legalidade ${ }^{13}$ das intervenções humanitárias, especialmente após a ação da OTAN no Kosovo, sem a autorização da CS, como veremos mais detalhadamente a seguir. De fato, não é possível afirmar que exista uma doutrina das intervenções humanitárias no Direito Internacional. ${ }^{14} \mathrm{O}$ desenho legal da CNU proíbe a intervenção por meio do artigo 2 (4), no qual o uso da força contra a territorial integrity and political independence dos Estados é vetado. A maioria dos juristas internacionais que defende essa proibição, ao mesmo tempo, reconhece a autoridade legal do Conselho de Segurança sobre as provisões do Capítulo VII da CNU para autorizar ações militares. No entanto, as ações militares autorizadas sob a jurisdição do Artigo 39 do Capítulo VII da CNU pela autoridade legal do CS devem ser restritas às situações de ameaça a international peace and security, o que configuraria a autorização de uma intervenção militar em bases humanitárias como ilegal.

Essa questão ganha importância no debate normativo porque coloca em oposição o elemento moral, que as intervenções reivindicam, ao elemento legal, baseado nas atribuições e proibições da Carta da ONU. A réplica moral ao argumento jurídico restricionista de que a intervenção humanitária sem a autorização do CS é ilegal e, portanto, proibida é de que a intervenção é um daqueles casos no qual as preocupações morais deveriam superar as determinações legais. Wheeler (2000) comparte desse argumento moral e dentro de sua concepção solidarista que propõe critérios de legitimidade para as intervenções não há a exigência do cumprimento da legalidade, representada pela autorização do CSNU.

Em resumo, os requisitos apresentados representam a indicação de que uma vez que os Estados decidam que uma intervenção humanitária é moralmente requerida, em uma situação de emergência humanitária suprema, estes devem usar a força de acordo com os requisitos de necessidade e proporcionalidade, somados à forte expectativa de que o uso da força alcance um resultado humanitário positivo, com ou sem a autorização da ONU.

\footnotetext{
${ }^{13}$ A questão da legalidade das intervenções humanitárias remonta à observação do dilema entre ordem e justiça no principal instrumento do Direito Internacional - Carta das Nações Unidas - que é o lócus das normas legítimas e compartilhadas pela sociedade internacional. O único elemento a respeito da legalidade das intervenções humanitárias que será considerado neste trabalho, após essa análise da Carta da ONU, é o caráter de ilegalidade das intervenções, perante o princípio de soberania estatal e as normas de não-intervenção e não-uso da força. Vale reiterar que não se pretende adentrar os debates sobre a existência ou não de um direito das intervenções humanitárias, baseados nas atribuições da CNU e nas competências de seus principais órgãos. A investigação da legalidade das intervenções humanitárias, ou mesmo da existência ou não de uma doutrina legal para esse fenômeno não estará entre os objetivos desse trabalho.

${ }^{14}$ Conferir MARQUES, Ivan. Intervenções Humanitárias: aspectos políticos, morais e jurídicos de um conceito em (trans) formação. Dissertação de Mestrado apresentada no Programa de Pós-Graduação em Relações Internacionais UNESP, UNICAMP, PUC-SP “San Tiago Dantas”, Campinas-SP, 2007.
} 


\subsubsection{Três ciclos de responsabilidade: dialogando com a proposta prática de Saving Strangers}

Após as experiências contrastantes de Ruanda (1994) e Kosovo (1998), o então Secretário-Geral da ONU Kofi Annan encorajou os membros da Organização a encontrar um novo consenso sobre as visões existentes entre a soberania nacional e as intervenções humanitárias ${ }^{15}$. Respondendo a esse desafio o Ministro das Relações Exteriores do Canadá, Lloyd Axworthy, criou a International Comission on Intervention and State Sovereignty (CIISE); em português, a Comissão Internacional sobre Intervenção e Soberania do Estado (CIISE). A CIISE reuniu um grupo de doze acadêmicos e intelectuais de diversas partes do mundo e de diferentes afiliações teóricas, a fim de que fosse redigido um relatório com as sugestões da CIISE para o referido dilema.

O relatório denominado Responsability to Protect (R2P) - em português, Responsabilidade de Proteger - acabou gerando um novo modelo conceitual cuja proposta principal era a reconciliação da tensão entre o princípio de soberania e a intervenção humanitária. O documento da Comissão estabeleceu três principais objetivos: propor uma alteração na linguagem conceitual de “intervenção humanitária” para "Responsabilidade de Proteger” ${ }^{16}$; fixar a responsabilidade das autoridades estatais em nível nacional e no Conselho de Segurança em nível internacional; e assegurar que as intervenções, quando ocorrerem, seriam conduzidas apropriadamente.

Dentre os resultados da Comissão, a última proposta que se refere especificamente ao grupo de critérios para a condução apropriada das intervenções humanitárias será analisada nessa seção a fim de aprofundar, buscando limites e avanços, dos argumentos da proposta solidarista de Nicholas Wheeler para as intervenções humanitárias. A proposta da CIISE trouxe em seu terceiro objetivo uma grande carga prática, representada em seis critérios, que deveriam ser observados para que a intervenção humanitária em questão fosse considerada legítima. Esses critérios guardam uma forte semelhança com os requisitos mínimos e

\footnotetext{
${ }^{15}$ ANNAN, Kofi. Facing Humanitarian Challenge: Towards a Culture of Prevention. New York: United Nations Dept. of Public Information, 1999.

${ }^{16}$ A mudança de um vocabulário conceitual de um direito ou dever de "intervenção humanitária" para a "Responsabilidade de Proteger” foi proposta a partir da carga histórica do termo 'intervenção humanitária’ que para as memórias históricas não-ocidentais se refere à imposição da vontade do mais forte sobre o mais fraco, em nome dos princípios prevalecentes no momento, desde a missão de civilização do Cristianismo à promoção dos direitos humanos. A proposição da "Responsabilidade de Proteger" é substituir os temores de dominação que o termo "intervenções humanitárias" carrega pelo elemento da solidariedade internacional da expressão "Responsabilidade de Proteger". (THAKUR, 2006, p. 250-1) Vale advertir que esse elemento não será tratado em nossa análise.
} 
adicionais da proposta empírica de Nicholas Wheeler para as intervenções humanitárias, que foram apresentados na seção acima.

Com um ano de separação entre a publicação do relatório da CIISE (2001) e o livro Saving Strangers (2000) de Wheeler, vale à pena realizar uma análise dos aspectos convergentes e divergentes entre as duas propostas, que embora não estejam distanciadas por um largo período de tempo, apresentam diferenças consideráveis que com certeza enriquecerão a análise em questão.

O primeiro grande diferencial entre a proposta prática para as intervenções humanitárias do relatório "Responsabilidade de Proteger” e a proposta prática de Wheeler é a ênfase e a valorização da prevenção como a dimensão mais importante desse conceito de responsabilidade que fundamenta a intervenção no relatório da CIISE. Isso significa que as opções para prevenção de situações que possivelmente levarão a intervenções humanitárias devem ser esgotadas, numa tentativa de atingir as causas primárias e não só as causas imediatas de uma determinada emergência humanitária.

A tarefa de prevenção que o relatório enfatiza deve seguir as medidas que visam o desenvolvimento do país, recomendadas pelo Programa das Nações Unidas para o Desenvolvimento (PNUD). Os Estados e as instituições regionais seriam os responsáveis por implantar as metas de promoção de desenvolvimento econômico e social, proteção de direitos humanos, accountability, e distribuição justa de recursos no interior do Estado.

A proposta solidarista de Wheeler, por sua vez, não reserva um lugar para o elemento da prevenção, embora a exploração empírica dos casos, realizada pelo autor em Saving Strangers (2000), tenha mostrado que as causas históricas, indiretas e enraizadas dos conflitos ou da falência estatal são as que mais agregam complexidade à implementação em campo dos mandatos das intervenções humanitárias. As causas societais e históricas que levam à uma situação de emergência humanitária suprema causam dúvida de que, mesmo em um caso hipotético em que todos os requisitos, mínimos e adicionais, propostos pelo autor, sejam observados, a intervenção humanitária terá de fato um resultado humanitário positivo, uma vez que essas causas exigem medidas difusas, complexas e de longo-prazo que nenhuma força militar, com mandato restrito e comprometimento de curto-prazo, é capaz de realizar.

Outro elemento destacado na proposta da Comissão é a 'responsabilidade de reconstrução’ que requer a completa assistência na recuperação, reconstrução e reconciliação da sociedade em que a intervenção foi realizada. A dimensão da reconstrução foi tangencialmente tratada por Wheeler, em Saving Strangers. O autor se referiu ao fato de que a 
ausência de mandatos de longo-prazo e do comprometimento dos Estados com os custos de uma missão longa interferiam na durabilidade do resultado humanitário positivo gerado.

Em resposta adiantada ao argumento de que o autor, dada a complexidade do tema, escolheu tratar somente da responsabilidade de intervir ou reagir como ato pontual e delimitado, é preciso dizer que soa no mínimo contra-intuitivo que uma proposta, na qual o indivíduo e a garantia de seus direitos básicos é o referencial da intervenção, não tenha compreendido uma noção mais ampla da justiça e da responsabilidade relacionada às intervenções humanitárias.

No que se refere ao grupo de requisitos básicos para conferir legitimidade às intervenções humanitárias a proposta da "Responsabilidade de Proteger" tem como diferencial a inclusão de dois critérios: “autoridade competente” e “intenção correta”. Os outros critérios são equivalentes aos desenvolvidos por Wheeler (2000): “último recurso" equivalente ao "requisito de necessidade”; “meios proporcionais” equivalente ao "requisito de proporcionalidade”; e “prospectivas razoáveis” equivalente ao “resultado humanitário positivo".

O critério de “autoridade competente" reivindica que a ONU, no papel do CS, continue a ser a responsável pela manutenção da paz e da segurança internacionais, decidindo por meio das resoluções do CS pela aprovação ou não das intervenções humanitárias. Sendo assim, os requisitos da proposta da CIISE foram formulados para que regulassem a prática das intervenções humanitárias autorizadas pelo CSNU, reforçando o posicionamento de manutenção da ONU como instância máxima de autoridade no plano internacional. Por outro lado, os requisitos mínimos e adicionais da proposta de Wheeler em Saving Strangers deveriam conferir legitimidade principalmente às intervenções humanitárias unilaterais. O autor não descarta totalmente o papel da ONU, já que mantém a autorização do CSNU como um critério adicional, capaz de conferir ainda mais legitimidade a uma intervenção humanitária que já tivesse observado os quatros critérios essenciais: emergência humanitária suprema, necessidade, proporcionalidade e resultado humanitário positivo.

Esse diferencial é bastante relevante, pois demonstra a discordância entre as duas propostas com relação ao papel do Estado soberano e ao papel da ONU, principalmente de seu CS, responsável pela aprovação das resoluções que autorizam as intervenções humanitárias. O relatório "Responsabilidade de Proteger” defende o papel central do Estado, como fonte de autoridade internacional e da ONU, como fórum insubstituível para autorizar o uso da força em bases legítimas no plano internacional. Portanto, a autoridade e a 
legitimidade de uma intervenção humanitária sem a aprovação do Conselho de Segurança da ONU não parece concebível ao relatório.

Grande parte dessa reafirmação do papel do Estado nacional e da autoridade do CS da Organização como o responsável pela chancela dessas ações, talvez possa ser atribuída ao fato de que a idéia da Comissão nasceu de uma exortação do Secretário-Geral da ONU, Kofi Annan, e foi liderado por um Ministro das Relações Exteriores de um Estado soberano (Lloyd Axworthy, do Canadá). Enquanto isso, a formulação teórica e acadêmica de Wheeler (2000) não tinha qualquer compromisso com a garantia de um papel central para o Estado nacional ou de um papel insubstituível para ONU, como instância máxima de legitimidade.

Sendo assim, a fonte de cada uma das formulações pode ter contribuído para essa diferenciação, o que não impede de pensarmos nessa questão como uma conseqüência da ambigüidade em torno da idéia dos Estados como os principais agentes da ordem mundial. Hurrell (2003, p. 40) atribui essa ambigüidade à normatividade solidarista que tem se desenvolvido crescentemente. A diferença entre a ordem pluralista, na qual os Estados são entendidos como "agentes" no sentindo estrito daqueles que agem ou exercem poder e o fazem por eles mesmos, e a expansão normativa da agenda do solidarismo criou o que podemos chamar de um problema de agência. Dentro dessa concepção solidarista, a agência ganhou um significado distinto: a idéia de um agente como alguém que age por, ou em nome de, outro.

"Within the solidarist order states are no longer to act for themselves as
sovereigns but rather, first, as agents for the individuals, groups, and national
communities that they are supposed to represent - hence the move towards
sovereignty as responsibility - and, second, as agents or interpreters of some
notion of an international public good and some set of core norms against
which state behavior should be judged and evaluated". (HURRELL, 2003, p.
40)

Essa questão da agência solidarista e da responsabilidade do Estado de agir em nome dos indivíduos em situação de extrema emergência humanitária explica porque diante do veto ou da indisposição do CSNU Wheeler (2000) não considera a autorização da ONU como critério fundamental de legitimidade para as intervenções humanitárias. Um caso emblemático de inação como o de Ruanda não poderia ser prerrogativa para que em num contexto de emergência humanitária suprema, uma intervenção humanitária não fosse realizada ou legitimada como de fato humanitária, por falta de aprovação do CSNU.

"That indifference and inaction by the international community remains one of the most shameful episodes since the Holocaust. This was not a matter of lack of knowledge and awareness, or even lack of capacity. Rather, it was a 
failure of collective conscience, of civic courage at the highest and most solemn levels of responsibility”. (THAKUR, 2006, p. 245)

Por isso, o autor reconhecendo as limitações impostas pelo CSNU às intervenções humanitárias endereçou seus esforços para definir critérios que legitimassem as intervenções humanitárias unilaterais, isto é, aquelas intervenções realizadas por um Estado ou por uma organização regional sem a aprovação do CSNU. A opção de intervenção humanitária unilateral legítima como norma, sem a defesa da extinção do poder de veto dos cinco membros permanentes (P5), como fez Wheeler (2000), foi duramente criticada por Ramesh Thakur (2006).

"Those who insist on retaining veto power but want to permit extra-
UN enforcement of community norms insist on keeping the very rules
that produce the outcomes they wish to reject. They cannot then claim
legitimacy: there is far too serious a problem of normative
incoherence (between intervention and procedural restrictions on the
use of force)". (THAKUR, 2006, p. 284)

A crítica de Takur representa bem o fundamento pluralista do pensamento da própria CIISE, cuja postura adotada em relação aos P5 do CSNU foi a de recomendar que o grupo deveria concordar em não aplicar o poder de veto em matérias onde seu interesse vital não estivesse envolvido e a maioria do CS estivesse apoiando essa aprovação de resoluções autorizando a intervenção militar para propósitos humanitários. "It would be far better to embed international intervention within the constraining discipline of the principles and caution underlying Responsibility to Protect than to risk the inherently more volatile nature of unilateral interventions”. (THAKUR, 2006, p. 285)

O relatório "Responsabilidade de Proteger” estabeleceu a “intenção correta” como segundo critério para que uma intervenção seja legítima e conduzida da melhor maneira possível. A intenção do documento foi de estabelecer que o elemento humanitário deveria ser a principal motivação para a intervenção, dada a quase impossibilidade de que uma intervenção militar seja única e exclusivamente conduzida por motivações humanitárias. As razões não-humanitárias são reconhecidas como legítimas pelo documento, desde que não atrapalhem a consecução do objetivo principal da intervenção.

A diferença entre as abordagens é que na proposta de Wheeler (2000) os motivos humanitários não pertencem ao esse grupo de condições mínimas e definidoras para que uma intervenção seja considerada humanitária. A recusa do autor em considerar os motivos 
humanitários como um critério mínimo é justificada pela intenção de privilegiar as vítimas que serão salvas como conseqüência do uso da força e não o Estado interventor e seus motivos para intervir. A lógica solidarista implícita (ou explícita?) nessa recusa é a substituição do Estado pelo indivíduo como o elemento de referência determinante para a ação.

$\mathrm{O}$ argumento de que os motivos deveriam ser o teste definidor de uma intervenção humanitária legítima, ou seja, a idéia de motives-first contraria a compromisso solidarista de sustentar padrões mínimos de humanidade comum, que coloque as vítimas dos abusos de direitos humanos no centro de seu projeto teórico, a fim de encontrar alternativas para que a sociedade internacional possa tornar-se mais hospitaleira à promoção da justiça na política mundial. Assim, a mudança do referencial dos Estados para as vítimas ora do poder estatal, quando este é o perpetrador das violações, ora da ausência da capacidade do poder estatal de proteger os direitos básicos de seus cidadãos, está fortemente baseada na percepção de que o Estado em ambas às situações perde as prerrogativas que o princípio da soberania estatal, apoiado pela norma da não-intervenção, lhe confere.

Dada a ausência das prerrogativas soberanas daquele Estado que é o perpetrador de, ou não é capaz de cessar, uma emergência humanitária suprema em curso, os Estados da sociedade internacional são moralmente chamados a intervir, devendo arcar com os custos econômicos e humanos dessa intervenção. Isso porque os Estados, de acordo com a premissachave do solidarismo, não são responsáveis somente pela proteção dos direitos humanos de seus cidadãos, mas sim de todos os indivíduos, quer sejam nacionais ou estrangeiros. $\mathrm{O}$ solidarismo recusa a concepção de que a soberania estabelece o limite das responsabilidades morais de um Estado, bem como de que as fronteiras soberanas são construções morais imutáveis.

A única ressalva, portanto, aos motivos não-humanitários é que estes não podem ser incoerentes com o objetivo máximo da intervenção, ou seja, com um resultado humanitário positivo. Caso esse motivos não-humanitários impeçam a realização desse objetivo máximo, a intervenção não poderá ser qualificada como humanitária. Sendo inversamente proporcional, mesmo uma intervenção que seja motivada por razões não-humanitárias, se os motivos e os meios empregados forem consistentes com um resultado humanitário positivo, ainda assim esta intervenção será considerada humanitária.

Apesar de suas diferenças e limitações evidenciadas após essa análise, que tomou a formulação solidarista de Nicholas Wheeler (2000) em paralelo com a "Responsabilidade de 
Proteger”, pode-se dizer que as duas propostas representam uma tentativa de reconciliar ordem e justiça na prática das intervenções humanitárias. O conflito entre soberania (ordem) e direitos humanos (justiça) foi repensado por essas duas perspectivas a partir de um contexto normativo que progressivamente tem transformado as graves violações de direitos humanos, perpetradas no interior da jurisdição doméstica de um Estado soberano, em matéria de dever moral, preocupação e responsabilidade internacional.

\subsubsection{Reconciliando ordem e justiça}

A apresentação dos requisitos mínimos e adicionais propostos por Nicholas Wheeler demonstra que a concepção solidarista de responsabilidade moral dos Estados não está restrita ou confinada às fronteiras da soberania estatal. O solidarismo coloca o indivíduo como referencial, antes e acima do Estado, construindo as bases de uma definição da justiça distinta da idéia pluralista de justiça. Essa matriz diferenciada se reflete nas proposições práticas, que visam conferir legitimidade às intervenções humanitárias, indicando a defesa do solidarismo por uma mudança nos horizontes morais da sociedade internacional, que torne legítima a decisão de intervir, mesmo sem a autorização legal, a fim de cessar terríveis abusos de direitos humanos no qual estrangeiros distantes dos limites nacionais estão sendo submetidos.

Em resposta aos temores pluralistas de que a proteção dos direitos básicos dos indivíduos, onde quer estejam, ameaça a manutenção da ordem internacional, os solidaristas argumentam que não é moralmente defensável, num mundo interdependente, concentrar-se somente nos interesses internos dos Estados e ignorar as obrigações com a humanidade. (FOOT, 2003, p. 12)

No caso das intervenções humanitárias, portanto, o justo definido por essa perspectiva solidarista está no entendimento de que um Estado, portador da obrigação suprema de proteger seus cidadãos e seus direitos fundamentais, não possa aproveitar-se de suas prerrogativas soberanas para desrespeitar essa obrigação, agindo como um Estado perpetrador de agressões a seus próprios cidadãos. Do mesmo modo, as mesmas prerrogativas também não deveriam ser válidas para Estados que não fossem capazes de garantir a observância desses direitos. Como resultado, portanto, dessas duas situações em que o Estado deixa de cumprir seu dever em relação a seus cidadãos, o solidarismo atribui essa responsabilidade ao dever moral da comunidade internacional. 
A grande mudança entre a justiça da CNU e a percepção de justiça solidarista é essa alteração de referencial do Estado soberano para o indivíduo como base das considerações por justiça. Essa alteração de referencial, a despeito da ilegalidade das intervenções humanitárias, considera tais intervenções como prática legítima. Desse modo, enquanto aos pluralistas cabe a tarefa de defender a manutenção da ordem como pré-condição para a realização de outros valores, aos solidaristas caberia, então, a função de pensar a justiça, ou melhor, o lugar e papel da justiça perante a ordem.

A relação entre ordem e justiça durante a maior parte do século XX, foi descrita pelos Estados e pela sociedade internacional como uma balança em que somente duas medidas poderiam ser obtidas. Essa balança ora marcava a tensão entre ambos, ora assinalava uma relação em que a visão de ordem tinha prioridade; ordem cujo cerne compreendia as condições mínimas para a coexistência em um mundo pluralista, onde o conflito é esperado e, no melhor dos casos, temporariamente contido. Nesse contexto, a busca por justiça era vista como secundária e, geralmente, como um desafio direto à manutenção da ordem internacional. (FOOT, 2003, p. 01),

Diante dessas considerações, a proposta solidarista sugere que a balança que mostrava a relação entre ordem e justiça ora pela medida da tensão entre ambas, ora pela preponderância absoluta da ordem, agora deve passar a mostrar uma terceira alternativa, na qual a justiça esteja presente. O que ainda é incerto é o peso que a justiça pode adquirir nessa medição. Parece improvável que nessa balança a justiça pese mais do que a ordem, mas o que já se sabe é que não é possível chegar a medidas válidas sem que a justiça esteja entre os pesos.

"A realist health warning must be added: the watchful concerns of states with power and the pursuit of interest endure. However, the realist reductionist fantasy, seeking to avoid the grand rhetoric of global justice and find the minimum conditions of coexistence, has had its day. No states take a position explicitly privileging order over justice. A wide range of justice issues is perceived by most states to be not merely a legitimate part of UN activities but an important contribution to international stability”. 


\section{CAPÍTULO II - O CETICISMO MORAL NAS RELAÇÕES INTERNACIONAIS: OBJEÇÕES REALISTAS E PLURALISTAS ÀS INTERVENÇÕES HUMANITÁRIAS}

"To an alarming degree the history of international relations is a history of
selfishness and brutality. It is a story in which spying, deceit, bribery,
disloyalty, ingratitude, betrayal, exploitation, plunder, repression, subjection,
and genocide are all to conspicuous. (...) Moral categories and judgments
are simply out of place in the realm of international affairs". (COHEN, 1985,
p. 3)

O ponto de partida para o exame de Marshall Cohen sobre o ceticismo moral e as relações internacionais está no trecho destacado acima. A intenção de Cohen, antes de iniciar a análise das duas formas de ceticismo moral das relações internacionais - forma realista e a forma hobbesiana - era mostrar, logo de início, que na história de egoísmo e brutalidade das relações internacionais não havia lugar para categorias e julgamentos morais.

É fundamentalmente a partir desse argumento da ausência de um lugar da moralidade na história das relações internacionais que nasce o objetivo deste capítulo: analisar a relação entre o ceticismo moral das relações internacionais e as objeções realistas e pluralistas às intervenções humanitárias, na tentativa de demonstrar por meio de casos empíricos - Índia (1971), Vietnã (1979) e Tanzânia (1979) - o alcance dessas objeções no processo de aceitação e legitimidade das intervenções humanitárias pela sociedade internacional durante o período de Guerra Fria.

O desafio que as intervenções humanitárias criaram para o ceticismo moral internacional perpassa as dimensões normativa, teórica e empírica das relações internacionais. Na dimensão empírica, o desafio deve-se ao fato de que intervir é usar a força militar em ações externas e, por vezes, distantes do território nacional sob justificativa moral humanitária arriscando a vida dos soldados nacionais em campo, o pagamento de um alto custo econômico, a desaprovação da opinião pública nacional e o risco de fracasso perante os complexos desafios desse tipo de crise.

Com relação à Teoria de Relações Internacionais, o desafio está na impossibilidade de manter o protagonismo da reflexão 'mainstream' realista, já que “for many years, it has been impossible to make moral arguments about international relations (...) without encountering the claim that moral judgments have no place in discussions of international affairs or foreign policy”. (BEITZ, 1999, p. 15) 
O estudo do fenômeno das intervenções humanitárias exige que os pesquisadores dessa disciplina encontrem outras possibilidades teóricas que permitam uma análise mais coerente e plausível desse fenômeno. À dimensão normativa, as intervenções humanitárias parecem dar novo ânimo na medida em que elas resgatam a importância do dever ser moral e ético nas relações internacionais.

Por todas essas razões, é possível afirmar que o principal motivo do caráter complexo e polêmico das intervenções humanitárias, bem como da origem de suas críticas mais ferrenhas, é o fato das intervenções reivindicarem um lugar - historicamente negligenciado dentro das relações internacionais enquanto prática política, teoria e dever ser - para as considerações morais.

Tendo em vista o que foi exposto acima, esse capítulo pretende investigar as origens do ceticismo moral nas relações internacionais e sua influência na formulação das objeções consequencialistas às intervenções humanitárias. O primeiro objetivo desse capítulo é analisar em que medida a ausência de um papel da moralidade nas relações internacionais como um todo e, principalmente nas ações que envolvem a decisão de intervir e o uso da força influenciaram ou definiram as objeções realistas e a objeção pluralista às intervenções humanitárias.

Num segundo momento, passaremos à análise de três casos empíricos de intervenção Índia (1992), Vietnã (1979) e Tanzânia (1979) - que segundo a perspectiva solidarista de Nicholas Wheeler (2000) não foram considerados legítimos, ou mesmo justificados em bases humanitárias, porque a ordem internacional fortemente baseada em normas pluralistas não permitiu. O contexto de Guerra Fria atuou determinantemente para que o princípio da soberania estatal, assim como as normas da não-intervenção e não-uso da força não pudessem ser questionados, mesmo diante de emergências humanitárias graves. Portanto, embora fosse possível que elas fossem justificadas como humanitárias, a partir da perspectiva do resultado humanitário positivo que geraram, o contexto que fortalecia as objeções realistas e pluralista foi decisivo para represália dessas ações pela sociedade internacional.

Da perspectiva da tensão entre ordem e justiça, esse capítulo irá mostar que a ordem internacional pluralista fundada na preponderância da ordem sobre a justiça condenou as ações das intervenções unilaterias dos anos 1970 que buscaram na justiça a condição para a ordem. 


\subsection{A paternidade do ceticismo moral internacional}

Antes de tratar especificamente das objeções realistas às intervenções humanitárias, é necessário recorrer à análise da fonte dessas objeções. Bem, caso seja possível atribuir a paternidade das objeções e críticas realistas às intervenções humanitárias a alguma formulação teórica, não resta dúvidas de que essa formulação é a hobbesiana. Sendo assim, essa seção pretende analisar os elementos que tornam possível atribuir a origem do ceticismo moral realista à formulação hobbesiana do estado de natureza.

Para tanto, essa análise será baseada em grande parte na contribuição de Charles Beitz na obra Political Theory and International Relations. Os argumentos críticos de Beitz a essa analogia serão utilizados tanto para introduzir a discussão a respeito do papel da moralidade nas relações internacionais como um todo quanto para entender a origem das objeções realistas às intervenções humanitárias em particular.

A investigação de Beitz parte de diversos elementos que poderiam ser a causa do ceticismo sobre a moralidade internacional, tais como o relativismo cultural ${ }^{17}$, a apreensão sobre os efeitos do 'moralismo’ na política externa, a visão de que as regras têm a obrigação prioritária de seguir o interesse nacional e a idéia de que não pode haver princípios morais de aplicação universal numa ordem mundial de Estados soberanos, para chegar a conclusão de que nenhum desses argumentos sustenta o ceticismo moral internacional, porque envolvem confusões elementares, suposições falaciosas, ou mesmo porque são incompletos.

O principal e mais poderoso argumento do ceticismo internacional, segundo Beitz, seria aquele que entende as relações internacionais como um estado de natureza, no qual as

\footnotetext{
${ }^{17}$ É interessante, apesar de sucinto, o tratamento de Beitz para o relativismo cultural como fonte importante, embora não principal, do ceticismo internacional. Segundo ele, diante das grandes disparidades nas visões de racionalidade e de bem prevalecente nas culturas do mundo, os céticos afirmam que não há bases racionais para sustentar uma moralidade social superior a outra quando os requisitos dessas moralidades conflitam. Para os céticos, culturas diferentes podem ter concepções radicalmente diferentes do que é moralidade e, nesse sentido, não existe o direito de confiar que uma concepção é correta ante das demais. A solução desse impasse colocado pelo relativismo cultural é sugerida por Beitz no sentido de que devemos estar preparados para reconhecer que alguma concepção de moralidade é mais razoável do que as outras, levando-se em conta as circunstâncias. Isso não significaria dizer que todos devem ser capazes de reconhecer a razoabilidade das mesmas suposições, mas sim que é necessário estabelecer padrões de conduta que nós somos capazes de considerar como as principais escolhas racionais disponíveis para qualquer um apropriadamente situado, considerando inclusive que esse problema não está limitado a ética internacional, já que isso também acontece internamente nas sociedades. Conferir em BEITZ (1999), p. 17-18.
} 
características estruturais de uma ordem mundial anárquica tornam a moralidade internacional impossível. Essa idéia, muito comum tanto na teoria política moderna quanto na teoria de relações internacionais, faria toda a diferença na construção e base para um entendimento do papel da moralidade nas relações internacionais. "The image of a global state of nature, in which nations are conceived as largely self-sufficient, purposive units, has been thought to capture the relative absence of moral norms governing relations among states”. (BEITZ, 1999, p. 03)

A analogia de Estados e pessoas presente tanto na concepção do ceticismo moral internacional quanto na concepção de uma moralidade de Estados é fortemente questionada por Beitz. Segundo ele, a analogia entre Estados e pessoas, que cria a conclusão normativa de que os Estados, assim como as pessoas, têm um direito à autonomia que os insula de crítica moral e interferência política externas, assim como fundamenta os princípios de nãointervenção e autodeterminação, é altamente equivocada. Primeiramente porque

\begin{abstract}
"Since states can no longer be regarded as largely self-sufficient political orders, the image of a global state of nature no longer provides an obviously correct picture of the moral relations among states, persons of diverse nationality, and other actors in the international realm”. (BEITZ, 1999, p. 04)
\end{abstract}

Em segundo lugar, porque a analogia adequada à autonomia individual no campo internacional não deveria ser com a autonomia nacional, mas sim com a conformidade das instituições políticas e econômicas de uma sociedade a princípios apropriados de justiça. Esse argumento é a idéia forte que Beitz defende ao longo do livro.

Além de rejeitar a analogia do estado de natureza de Hobbes com as relações internacionais ${ }^{18}$, Beitz rejeita também as duas principais premissas fundadoras do argumento hobbesiano para o ceticismo internacional. A primeira premissa é aquela em que entende o estado de natureza como um estado de guerra, no qual nenhum Estado tem preocupações prioritárias em seguir as normas morais que restringem a busca de interesses políticos mais imediatos e importantes. A segunda premissa está baseada no argumento teórico que afirma que os princípios morais deveriam ser justificados pelo fato de que segui-los promove o interesse próprio de longo prazo de cada agente aos quais eles se aplicam. Ambas são

\footnotetext{
${ }^{18}$ A rejeição da analogia do estado de natureza de Hobbes com as relações internacionais será tratada nas próximas seções desse capítulo.
} 
rejeitadas pelo autor; a primeira porque envolve uma percepção imprecisa da estrutura e dinâmica da política internacional contemporânea e a segunda porque dá uma explicação incorreta da base dos princípios morais e do caráter moral do Estado.

Para entender tanto o equívoco da analogia indivíduo/Estado nacional ou estado de natureza/relações internacionais, quanto às críticas de Beitz às premissas da formulação hobbesiana que fundamentam o ceticismo moral internacional, é necessário analisar a formulação de Hobbes e a resultante analogia do estado de natureza hobbesiano com as relações internacionais.

De acordo com Hobbes, o estado de natureza é definido pela ausência de uma autoridade política suficientemente poderosa para assegurar a segurança do povo e os meios para uma vida com felicidade. A ausência dessa autoridade política no estado de natureza hobbesiano fundamenta a idéia de que não é possível existir princípios morais efetivos ${ }^{19}$ sem um governo com poder para recompensar o cumprimento e punir o não-cumprimento, ou seja, regular e obrigar a observância dos princípios e regras morais acordados. A ausência de uma autoridade que dê garantia de cumprimento recíproco às normas morais elimina qualquer razão para se falar em moralidade no estado de natureza. A moralidade é entendida, nesse caso, como:

“(...) a system of rules that promotes each person's overriding interests, and hence to which person has reason to adhere, only when everyone (or almost everyone) complies with them. In other words, a condition of the rationality of acting on moral rules is that one have adequate assurance of the compliance of others”. (BEITZ, 1999, p. 28)

Sem uma instância superior que seja capaz de fazer com que as "leis da natureza" apliquem-se efetivamente aos agentes independentes do estado de natureza, é inútil esperar uma garantia de que todos esses agentes irão seguir as “leis da natureza” hobbesiana. Mesmo se considerarmos a existência de princípios morais no estado de natureza, juntamente com suas "leis da natureza”, eles não obrigam à ação na ausência de um poder comum. Considerando, portanto, que as normas morais não podem exigir que um homem ou uma nação façam o que eles não têm razão para fazer, desde que não seja seu próprio interesse

\footnotetext{
${ }^{19}$ Beitz usa a adjetivação 'efetivo' para os princípios morais para descrever princípios com os quais os agentes têm uma obrigação. Os princípios efetivos obrigam "in foro externo" e não são meramente princípios que regulariam um mundo preferido, mas que não se aplicam diretamente ao mundo existente. (BEITZ, 1999, p. 28)
} 
individual no caso do primeiro e nacional no caso do segundo, seria irracional aderir a normas morais na ausência de uma expectativa confiável de que os outros farão o mesmo. Os céticos internacionais se valeram dessa característica da teoria hobbesiana para apoiar a visão de que não há obrigações morais efetivas nas relações internacionais. (BEITZ, 1999, p. 31)

\subsection{As relações internacionais como um estado de natureza hobbesiano}

De acordo com Beitz, a aplicação da concepção hobbesiana de estado de natureza às relações internacionais serve a duas funções diferentes ao argumento de ceticismo internacional. A primeira função é a de fornecer um modelo analítico que explica a guerra como o resultado de propriedades estruturais das relações internacionais. Isso produz a conclusão de que o conflito entre os atores internacionais irá resultar em estado de guerra na ausência de poder superior capaz de impor regras reguladoras.

Já a segunda função se refere ao modelo de justificação moral proveniente do estado de natureza que explica como os princípios normativos para as relações internacionais deveriam ser justificados. Esse modelo baseia-se no fato de que a base da aquiescência de um Estado a normas morais é seu interesse próprio, sendo assim a justificação para tais normas deveria apelar para àqueles interesses que os Estados têm em comum. Enquanto o primeiro uso dessa idéia de um estado de natureza internacional levaria à predição ou previsão sobre o comportamento dos Estados, o segundo levaria a prescrição de ações para esses Estados. (BEITZ, 1999, p. 35)

\subsubsection{A função preditiva da concepção de relações internacionais como um estado de natureza hobbesiano: o estado de guerra}

A analogia que nos permite falar em estado de natureza internacional e que prevê as relações internacionais como um estado de guerra só pode verificar-se caso as quatro proposições seguintes forem verdadeiras: 
1. $\quad$ Os atores nas relações internacionais são os Estados;

2. Os Estados têm relativamente poder igual (o mais fraco, ou uma coligação dos mais fracos, pode derrotar o mais forte);

3. Os Estados são independentes uns dos outros para dirigir suas relações internas independentemente das políticas internas de outros atores;

4. Não há expectativas confiáveis de obediência recíproca pelos atores a regras de cooperação se não houver um poder superior capaz de impor essas regras. (BEITZ, 1999, p. 36)

Caso essas condições não se verifiquem nas relações internacionais, isso impede que se confirme ou se mantenha a analogia entre o estado de natureza e as relações internacionais, assim como a predição de que as relações internacionais são um estado de guerra. (BEITZ, 1999, p. 36) A estratégia de Beitz para contestar essa analogia e a predição das relações internacionais como um estado de guerra é por meio da análise e da verificação da possibilidade de se observar ou não cada um desses pontos. Esse verdadeiro escrutínio e o seu resultado serão bastante úteis a presente pesquisa uma vez que permitirão, quando da apresentação das objeções realistas às intervenções humanitárias, o questionamento da premissa realista de que as relações e os fenômenos internacionais podem ser entendidos a partir da idéia de estado de natureza hobbesiano.

A primeira condição, que estabelece os Estados como os atores determinantes das relações internacionais, é importante para o argumento dos céticos internacionais, uma vez que o individualismo radical do estado de natureza de Hobbes ajuda a tornar plausível a predição de um estado de guerra, pois essa idéia nega "the existence of any other actors (...) that might mediate interpersonal conflict, coordinate individual's actions, insulate individuals from the competitio of others, share risks, or encourage the formation of less competitive attitudes”. Num paralelo com os Estados, essa concepção do individualismo radical que confirma a predição do estado de guerra, se dá na medida em que "the view that states are the only actors in international relations denies the possibility of analogous international conflict-minimizing coalitions, alliances, and secondary associations”. (BEITZ, 1999, p. 37)

O problema com esse argumento é que o próprio Hobbes permite a possibilidade de coalizões e alianças no estado de natureza interpessoal, apesar da instabilidade das mesmas. 
Para Hobbes, além de serem instáveis, essas coalizões e alianças até aumentariam as chances de violência no estado de natureza e os interesses divididos que por ora tivessem levado à sua formação não cooperariam por muito tempo.

No plano internacional, essa analogia claramente não é plausível, porque embora algumas coalizões e alianças possam aumentar as chances de guerra, há outros inúmeros tipos de coalizões que produzem resultados positivos. Beitz cita o exemplo das organizações políticas e econômicas regionais e até a própria ONU. Ao argumento de que as coalizões não duram no tempo, Beitz questiona: quanto tempo uma coalizão minimizadora de conflito deveria durar? E ele responde, que por certo, elas não deveriam durar para sempre, mas sim enquanto contribuíssem significantemente para a paz e a cooperação.

Outro ponto importante a ser questionado em relação a essa primeira condição é o fato de que considerar somente os Estado como os atores das relações internacionais nega a possibilidade de considerar que associações transnacionais de indivíduos com interesses comuns poderiam exercer pressão sob seus respectivos governos nacionais. Nesse ponto, Beitz lembra que desde a II Guerra Mundial, o número, a variedade, os membros e a importância desses grupos transnacionais têm aumentado, em alguns casos dramaticamente.

"The view does so by obscuring the fact that states, unlike persons, are aggregations of units (persons and secondary associations) that are capable of independent political action. These units might be grouped according to other criteria than citizenship, for example, according to interests that transcend national boundaries”. (BEITZ, 1999, p. 38)

Esse contexto em que novos atores exercem um papel significativo nos rumos políticos domésticos e internacionais faz enorme sentido para o tema das intervenções humanitárias. Como veremos no capítulo a seguir, em especial quando os casos empíricos forem tratados, esses atores transnacionais, em especial as ONGs internacionais de direitos humanos, tiveram um papel de relevância destacada na sensibilização da opinião pública internacional, bem como no processo decisório de aprovação das intervenções humanitárias pela ONU.

O caso da Somália é bastante ilustrativo sobre como a atuação das ONGs internacionais de direitos humanos influenciaram a aprovação da intervenção humanitária nesse país. As agências de ajuda humanitária foram as primeiras a atuar na distribuição de alimentos e suprimentos básicos à população civil somali que estava morrendo de fome e má 
nutrição, na tentativa de impedir o agravamento daquela grave crise humanitária. Essas agências, que eram extorquidas e chantageadas pelas milícias armadas rebeldes do conflito, chegaram a desembolsar enormes quantias monetárias para garantir que a ajuda humanitária básica chegasse aos civis somalis. A situação de extrema insegurança e exploração a que essas agências estavam submetidas no país foi um elemento importante para a formação da pressão internacional que exigia que alguma providência fosse finalmente tomada em relação ao caso. Como veremos na análise do caso somali no Capítulo III desse trabalho, a pressão da opinião pública doméstica dos Estados Unidos, chocada com as imagens assustadoras de milhares de centenas de somalis, principalmente as mulheres e crianças, mortas por inanição influenciou determinantemente a decisão do Presidente Bush de liderar a Operação Restore Hope, enviando soldados americanos à Somália no ano de 1992.

"The theoretical importance of the rise of transnational politics lies
elsewhere. It lies in the fact that nation-states can no longer be regarded as
the only, or as the ultimate, actors in international relations, since their
actions may be influenced significantly by pressures from groups that
represent transnational interests. Depending on the strength and extent of
theses interests, this new element of complexity in international relations
renders problematic the Hobbesian explanation of why international
relations should be regarded as a state of war". (BEITZ, 1999, p. 40)

A segunda condição, segundo a qual é possível que os Estados tenham relativamente poder igual, na medida em que o Estado mais fraco possa derrotar o Estado mais forte, tem relevância especial para o argumento de que o estado de natureza hobbesiano é um estado de guerra. No estado de natureza primário, em que todos os Estados teriam chances iguais, não haveria possibilidade de que o poder preponderante de um ator ou coalizão chegasse a uma ditadura ou império. Nessa condição de chances iguais, todos estariam igualmente sujeitos a sofrer danos à própria autopreservação no caso de um estado de guerra.

A verdadeira complexidade dessa condição, segundo Beitz, não está na idéia de nãodominância, já que nenhum ator seria forte o bastante para dominar todo o resto. O que de fato é importante na segunda condição que define o estado de natureza hobbesiano é que a ação conforme as leis da natureza e a ação para escapar do estado de natureza são igualmente irracionais. Nesse sentido, as ações tomadas por qualquer ator no intuito de promover o desenvolvimento de condições para que o comportamento moral (nesse caso, o comportamento de acordo com as leis da natureza) seja justificado racionalmente são consideradas irracionais. (BEITZ, 1999, p. 40-1) 
A aplicação dessa condição de poder igual (no sentido de chances iguais) aos Estados nas relações internacionais contemporâneas é facilmente objetável, já que existem muitas disparidades em níveis relativos de poder nacional. O que resta, no paralelo internacional dessa condição, é explicar porque alguns Estados, em especial os mais fortes, não poderiam ou não teriam a obrigação de tentar mudar as regras do jogo internacional prestando, por exemplo, obediência a normas morais. Fica evidente que o interesse de aplicação da condição de não-dominância às relações internacionais está muito mais ligado a intenção de tornar irracional um movimento de mudança das bases organizacionais e valorativas das relações internacionais, liderado pelos Estados mais poderosos do sistema, do que realmente atribuir ou mesmo confiar num cenário de poder igual entre os Estados.

Essa questão também pode ser facilmente relacionada às intervenções humanitárias, em especial quando pensamos no papel que as grandes potências exercem ou poderiam exercem diante da necessidade de cessar emergências humanitárias graves. Nesses casos, as grandes potências são chamadas à responsabilidade de ação liderando ações práticas que possam ter efeito imediato na catástrofe em questão, como o envio de tropas militares em curto espaço de tempo. O papel que essas grandes potências podem exercem nas discussões das reuniões do Conselho de Segurança da ONU também por ocasião de um caso que configure uma intervenção humanitária é, sem dúvida, fundamental.

Em algumas ocasiões, a condução do processo decisório no sentido de que o Conselho aprovasse uma operação com mandato de uso da força por alguma potência foi determinante para a aprovação da intervenção. Foi o caso da liderança dos Estados Unidos com relação à aprovação da Operação Restore Hope da Somália, na qual as tropas americanas teriam o comando da missão até que fossem restabelecidas as condições mínimas para a entrega de ajuda humanitária aos somalis. O mesmo aconteceu na aprovação da Operação Turquesa pelo CS da ONU, que autorizou a intervenção para cessar o genocídio em Ruanda (1994) somente após a França ter se oferecido para lidarar a missão.

Conceber os Estados como capazes de dirigir suas relações internas independentemente das políticas internas de outros atores é a terceira condição dessa analogia com o estado de natureza hobbesiano, no qual as partes, buscando independentemente seus interesses, irão provocar violentos conflitos. Essa proposição também não pode ser aplicada às relações internacionais contemporâneas, dado o nível de interdependência no qual os Estados se encontram. Atualmente, tanto a segurança quanto a prosperidade de qualquer 
Estado dependem cada vez mais dos outros Estados; mesmo a busca pelo interesse próprio de um Estado provavelmente irá requerer a cooperação com outros Estados do sistema.

Essa interdependência explica o crescimento das instituições e práticas internacionais condensadas na idéia de regimes internacionais - que organizam as rivalidades dos Estados em modos que requerem a cooperação para a manutenção das práticas já acordadas e para a resolução dos conflitos por meios não violentos. "There is no doubt that such practices and institutions (...) have come to occupy a far more important place in international relations than previously as a result of the increasing volume and significance of transnational transactions”. (BEITZ, 1999, p. 43)

Como resultado disso, o caráter do poder nas relações internacionais contemporâneas tem sido transformado. A capacidade de um Estado de fazer com que os outros Estados ajam (ou não ajam) nas formas que não agiriam ou (agiriam), ou seja, o poder de um Estado, embora tenha o uso ou a ameaça de violência como seu instrumento paradigmático, não há nada que limite os instrumentos do poder aos instrumentos de violência. Nesse sentido, a associação comum em instituições ou a participação comum em algumas práticas geralmente constituem formas de não violentas de poder.

Os céticos enxergam nessas novas formas de poder, resultantes da atuação desses novos atores e, por conseqüência, de novos relacionamentos na política internacional como uma razão para esperar que o uso ou a ameaça da violência se torne mais freqüente. "Since more is at stake in international relations now than previously, one might conclude, states have more reasons rather than fewer for using violence or its threat to protect and advance their interests”. (BEITZ, 1999, p. 45)

Ao contrário do que crêem os céticos, o crescimento dessas novas formas de poder simplesmente reflete o fato de que os Estados demandam mais das relações internacionais agora do que passado e que os mecanismos internacionais geralmente requerem condições ambientais estáveis e suporte consensual externo rebatendo a suspeita de que o recurso à força é cada vez mais utilizado. Tanto é diferente que o número de conflitos ou guerras convencionais entre Estados é cada vez menos freqüente, já que as contendas e rivalidades são em grande medida solucionadas pacificamente dentro desses novos mecanismos internacionais. 
A quarta e última condição se refere à ausência de expectativas confiáveis de obediência recíproca às regras de cooperação pelos atores na ausência de um poder superior capaz de impor essas regras. No âmbito internacional, essa condição é também não pode ser constatada segundo Beitz, porque embora não haja um direito internacional efetivo e uma força policial que garantam a vida das nações no estado de natureza, a comunidade internacional possui uma variedade de recursos para promover a obediência às normas estabelecidas, como a desaprovação da comunidade e a censura pelas organizações internacionais, com a aplicação de embargos, por exemplo. Pensando a partir de um mundo onde os Estados fazem parte de um sistema internacional não hierarquicamente ordenado, é possível falar em ordenamento horizontal que envolve expectativas substanciais de obediência recíproca em relação às regras de cooperação.

\footnotetext{
"The point is that the concerns of international relations have broadened considerably, with the result that competition among international actors may often take a variety of nonviolent forms, each requiring at least tacit agreement on certain rules of the game that express important common interests of the actor involved. The actors in international politics, their forms of interaction and competition, their power, and the goals the system can promote have all changed”. (BEITZ, 1999, p. 48)
}

Nesse contexto em que se pode falar na expectativa de obediência recíproca e de cumprimento às regras e compromissos assumidos, é possível também falar a respeito da aquiescência com relação às regras morais, mesmo que os Estados não sejam obrigados a observá-las a menos que seja do interesse deles. Isso é possível diante da premissa de que os Estados possuem interesses que vão muito além da sumária concepção de interesse nacional ligado à sobrevivência e herdado da idéia de estado de natureza hobbesiano. Os Estados possuem interesses comuns e há bases razoáveis para esperar a aquiescência recíproca no que se refere às regras que promovem esses interesses, mesmo na ausência de uma autoridade coercitiva superior.

A não-verificação de nenhuma das quatro condições acima, as quais permitiriam confirmar a validade da analogia entre o estado de natureza hobbesiano e as relações internacionais, predizendo as últimas como um estado de guerra, demonstra a complexidade do fenômeno contemporâneo das relações internacionais, que seria obscurecida caso o modelo de relações internacionais como um estado de natureza no qual o principal problema é a guerra fosse aceito como plausível e válido. 


\subsubsection{A função prescritiva da concepção de relações internacionais como um estado de natureza hobbesiano: o interesse nacional}

A segunda função, prescritiva, do uso da analogia do estado de natureza às relações internacionais trata da justificação dos princípios reguladores para a vida internacional ou política. Esse grupo de princípios seria a escolha mais racional possível para pessoas situadas no estado de natureza. Analogamente aos princípios racionais do estado de natureza, os princípios para a política doméstica e internacional deveriam ser justificados, respectivamente, por considerações de auto-interesse individual e nacional.

O problema, apontado por Beitz, ao avaliar o uso prescritivo da versão internacional do estado de natureza hobbesiano não é determinar se há interesses comuns entre os Estados que podem dar origem a regras de cooperação, ou mesmo se as circunstâncias das relações internacionais já permitem que os Estados sigam essas regras sem um risco inaceitável. Ao contrário, o que se deve questionar, segundo ele, é se a concepção de Hobbes aplicada às relações internacionais fornece uma teoria aceitável de justificação de princípios morais. Mais ainda, se a justificação de princípios morais para as relações internacionais deveriam basearse em última análise somente nas considerações sobre os Estados e somente sobre os interesses desses Estados.

O argumento de que os Estados deveriam perseguir seus próprios interesses na ausência de expectativas confiáveis de aquiescência recíproca às regras comuns está diretamente relacionado à analogia entre as pessoas no estado de natureza interpessoal e os Estados nas relações internacionais. No caso interpessoal, a idéia de que as pessoas podem buscar seus interesses sem restrições por regras morais pode ser vista plausivelmente porque é possível assumir que cada pessoa tem o direito de autopreservação. Por analogia, na esfera internacional, os dilemas morais são diferentes daqueles enfrentados pelo cidadão comum e, quando a moralidade política $^{20}$ entra em conflito com normas morais a raison d'état determina que "statesmen are entrusted with the fate of those who form part of their political community, and must base theis foreign policy decisions on whatever serves the well being of their own citizens”. (WELSH, 2004, p. 58)

\footnotetext{
${ }^{20}$ Moralidade política no sentido utilizado por Martin Wight, ou seja, aquela moralidade que não parte do direito natural nem se trata de moralidade internacional. Cf. em: WIGHT, 1966, apud WELSH, 2004, p. 58.
} 
A raison d'état estabelece como função do Estado a responsabilidade do governante daquele Estado de proteger o interesse nacional estatal. O privilégio do interesse nacional sobre qualquer argumento influenciou fortemente a tradição da teoria do contrato social no pensamento ocidental. No contratualismo, "the state exists as a discretionary association for the mutual advantage of its members for the mutual advantage of its members, and the government as an agent whose duty is to serve the basic interests of those members". (WELSH, 2004, p. 59) Portanto, no contratualismo derivado da concepção hobbesiana, a busca do interesse nacional pelos líderes do Estado nada mais é do que realizar a tarefa a que eles foram autorizados. "States leaders have an 'overriding fiduciary obligation' to serve the interests of their own citizens and cannot use the resources of the state to improve the lot of outsiders”. (WELSH, 2004, p. 59)

A questão, no entanto, é saber até onde vai o direito de colocar o interesse nacional acima de normas morais, respaldado pelo direito de auto-preservação e como este direito pode ser justificado. "The dificulty is that it is not clear what such a right involves or how it can be justified. States are more than aggregations of persons; at a minimum, they are characterized by territorial boundaries and a structure of political and economic institutions. How much of this (...) is covered by the presumed right of national self-preservation?” (BEITZ, 1999, p. 52).

A plausibilidade desse argumento de um direito básico de auto-preservação nacional, portanto, serve para limitar que qualquer idéia de nação seja expandida. Essa limitação poderá ser claramente observada nas objeções à intervenção humanitária, em que o próprio público doméstico de um Estado que se disponha a intervir por motivos humanitários geralmente é “criticized for 'globe-trotting' rather than focusing on domestic policy priorities. De modo geral, as objeções realistas e os casos de intervenção humanitária analisados a seguir exemplificarão a contento a presença do argumento da raison d'état nas objeções à prática das intervenções humanitárias.

\subsection{Premissas realistas para o ceticismo moral e ético internacional}

"Embora o indivíduo conte com o direito moral de sacrificar-se em defesa de tal princípio moral, o Estado não tem o direito de permitir que sua desaprovação moral (...) constitua um obstáculo à ação política vitoriosa, ela própria inspirada pelo princípio moral de sobrevivência nacional”. (MORGENTHAU, 2003, p. 20) 
Essa afirmação de Morgenthau é emblemática da incorporação da formulação hobbesiana do estado de natureza à formulação realista cética aos princípios morais e éticos nas relações internacionais. As considerações a seguir pretendem demonstrar as continuidades entre a formulação hobbesiana e as proposições céticas do realismo político. A partir dessa análise, pretende-se investigar em que medida essas continuidades entre a formulação hobbesiana e as proposições céticas do realismo originaram as objeções realistas às intervenções humanitárias.

Da citação acima, é possível extrair duas relevantes e fundamentais idéias realistas céticas. A primeira delas se refere à proposição realista de que as escolhas em política externa serão equivocadas se tiverem como ponto de partida considerações morais. Marshal Cohen interpreta essa proposição como mais um dos mal-entendidos dos escritos realistas em relação a natureza da moralidade, que acaba por contribuir para o ceticismo realista sobre o papel da moralidade nas relações internacionais. Os realistas geralmente sugerem que por causa de atitudes 'moralistas' ou 'legalistas' serem irrelevantes, e mesmo perigosas, nas relações internacionais, a moralidade e o Direito também seriam irrelevantes e perigosos. Cohen concorda com a crítica realista ao 'moralismo', mas adverte que “(...) 'moralism' is not morality, and showing that 'moralistic' attitudes and policies have a pernicious influence on foreign policy does not show that morality itself must be banished from the realm of international affairs”. (COHEN, 1985, p. 07)

O segundo argumento realista que pode ser retirado deste excerto de Morgenthau é aquele para qual o entendimento do comportamento internacional não pode estar baseado na crença de que os Estados tenham os mesmos padrões morais que os indivíduos. Beitz questiona porque seria errado fazer julgamentos morais sobre o comportamento internacional se julgamos que é correto fazê-los sobre o comportamento doméstico ou interpessoal. A não ser adotando-se um ceticismo moral e ético generalizado, não seria consistente manter o argumento de que há restrições morais à ação individual, mas não há as mesmas restrições à ação dos Estados. Esse ceticismo moral geral, e seu conseqüente ceticismo sobre a ética na política representam, na verdade, a recusa em aceitar argumentos morais como fontes de razão para ação.

Para os realistas, o interesse nacional, definido em termos de poder, é a única base racional possível, o que nega a validade de recorrer aos julgamentos morais sobre o 
comportamento dos Estados no plano internacional. A desaprovação moral não pode constranger a busca dos interesses nacionais de um Estado.

"A more tempting argument for the realist view that international conduct is improperly guided or judged by moral standards supposes that actions which seem to be politically acceptable in international realm appear to be condemned by morality, and that morality must, therefore, be irrelevant to the judgment of international conduct”. (COHEN, 1985, p. 04)

Logo, para os realistas, agir de acordo com o interesse ou razão de Estado é fazer o que é (moralmente) certo. Contudo, buscar o interesse próprio, embora seja a opção racionalmente aconselhável e correta no estado de natureza hobbesiano, não implica necessariamente ações moralmente certas. O mesmo acontece no paralelo com o Estado, cuja busca pelo interesse nacional nem sempre produz uma ação moralmente correta nas relações internacionais. Quanto a isso, os realistas utilizam-se das considerações sobre a responsabilidade dos líderes políticos para com seus cidadãos. “O indivíduo pode dizer a si próprio: 'Fiat justitia, pereat mundus ${ }^{21}$, mas o Estado não tem o direito de fazer o mesmo, em nome daqueles que estão aos seus cuidados.” (MORGENTHAU, 2003, p. 20)

Os líderes dos Estados, portanto, deveriam seguir o interesse nacional porque esta é a obrigação deles enquanto detentores da confiança do povo. Fazer o contrário seria uma irresponsabilidade. Os políticos têm que distinguir "entre o seu 'dever oficial', que implica pensar e agir em função do interesse nacional, e o seu 'desejo pessoal', que é o de ver seus próprios valores morais e seus princípios políticos realizados em todo o mundo". (MORGENTHAU, 2003, p. 09) Beitz aponta que o problema com essa abordagem do "dever oficial” é que envolve a concepção de que os cidadãos de um Estado têm o direito de que qualquer coisa que seja feita em nome deles possa ser descrita como interesse nacional. Segundo ele, "this is a just as much in need a proof as international skepticism itself". Nas relações domésticas, as pessoas têm o direito de que o que Estado possa fazer por elas seja limitado pelo que elas próprias têm o direito de fazer. Isso significa que, por exemplo, se os cidadãos de um Estado não têm o direito de escravizar dez por cento da população, o Estado não o tem direito de fazer isso por eles, ou em nome deles.

Beitz entende que não há razão para que seja o “dever oficial” no plano internacional seja diferente no plano doméstico. Portanto, o que os líderes políticos podem fazer, com todo

\footnotetext{
${ }^{21}$ Que se faça justiça, mesmo que o mundo pereça. Conferir em MORGENTHAU, 2003, p. 20.
} 
o direito, por seus cidadãos, seja no plano internacional seja no doméstico, é limitado pelo que os cidadãos podem, com todo o direito, fazer por eles mesmos. O que significa que a “(...) the responsibility of leaders to their constituents is not necessarily to follow the national interest wherever it leads, without regard to the moral considerations that would constrain groups of individuals in their mutual interactions”. (BEITZ, 1999, p. 24) Segundo essa perspectiva, o apelo à responsabilidade dos líderes para com seus cidadãos, por fim, não prova que é sempre certo para os líderes buscar o interesse nacional.

Apesar disso, a teoria realista em seu conjunto reforça seu forte ceticismo moral ao manter a proposição de que ao Estado cabe a definição do interesse nacional sem qualquer incidência de restrições morais. "The realists argue that international relations is, and should be, guided and judged exclusively by the amoral requirements of the national interest”. (COHEN, 1985, p. 04) Logo, os líderes políticos não poderiam ser criticados pelos objetivos, meios e condução da política externa segundo bases morais. Desse modo, o Estado estaria sempre moralmente justificado ao agir perseguindo seus interesses, especialmente diante de certas características da ordem internacional que tornam os julgamentos morais inapropriados, a exemplo da soberania nacional.

A ação internacional sob o ponto de vista da concepção de soberania não pode sujeitar os Estados a requisitos morais internacionais uma vez que cada Estado representa uma unidade política autônoma e distinta das outras sem qualquer autoridade comum entre elas. Essa ausência de autoridade comum superior, assim como no estado de natureza hobbesiano, justificaria o fato de que as que soberanias inseridas na anarquia internacional não teriam suas ações competitivas restringidas por um senso de avaliação moral da ação internacional ${ }^{22}$.

A base dessa proposição realista também está na formulação hobbesiana, mais propriamente na teoria da obrigação de Hobbes, em que “(...) people have no obligation to perform actions when performance cannot be shown to advance their (long-range) selfinterests”. (BEITZ, 1999, p. 31) Considerando que a teoria da obrigação de Hobbes é puramente prudencial, essa proposição realista também será, na medida em que

“(...) o realismo considera que a prudência - a avaliação das conseqüências decorrentes de ações políticas alternativas - representa a virtude suprema da

\footnotetext{
${ }^{22} \mathrm{O}$ argumento de Beitz para rejeitar essa idéia é baseado na analogia com as relações domésticas. Dentro de um Estado, há diversas áreas de relações interpessoais e sociais que não estão sujeitas a regulação legal, mas sobre a qual os indivíduos sentem a necessidade e o compromisso significativo da avaliação moral. Ver: BEITZ, 1999, p. 27.
} 
política. A ética, em abstrato, julga uma ação segundo a conformidade da mesma com a lei moral; a ética política julga uma ação tendo em vista as suas conseqüências políticas”. (MORGENTHAU, 2003, p. 20)

A aplicação da teoria da obrigação (prudencial) de Hobbes às relações internacionais resulta na idéia de que a ação oficial dos agentes de Estado não precisa estar de acordo com princípios morais, já que esses princípios não são efetivos perante a ausência de expectativa confiável de cumprimento recíproco.

\footnotetext{
“The necessity (or 'duty') to follow the national interest is dictated by a rational appreciation of the fact that other states will do the same, using force when necessary, in a manner unrestrained by a consideration of the interests of the other actors or of the international community”. (BEITZ, 1999, p. 28)
}

\subsection{As objeções da teoria realista às intervenções humanitárias}

O núcleo das objeções do paradigma realista às intervenções humanitárias possui ao menos os quatro grandes argumentos a seguir: questão do interesse nacional, a seletividade, o problema do abuso e a concepção de dever estrito do Estado para com seus cidadãos. Todos eles claros frutos do ceticismo moral realista que não concebe que os Estados se comportem moralmente no ambiente anárquico das relações internacionais.

O primeiro e mais emblemático dos argumentos, já que dele derivam os demais, é a questão do interesse nacional. "States should further their own national interest because (if all states do this) it is likely to procuce the best overall outcome. In formulating foreign policy statesmen should not aim to maximize global well-being directly, but rather focus on the imemediate interests of their own citizens". (WELSH, 2004, p. 62) Sob tal argumento, um Estado não intervirá, arcando com os custos dessa ação como arriscar a vida de seus soldados e sujeitar-se a significativos custos econômicos, sem que os interesses vitais desse Estado estejam em jogo. Os Estados, de acordo com esse argumento, não podem intervir primariamente por razões humanitárias porque eles são sempre motivados por considerações de interesse próprio, isto é, do interesse nacional. (WHEELER, 2000, p. 29)

É do interesse nacional que surge à seletividade, razão da segunda grande objeção realista às intervenções humanitárias. De acordo com os realistas, os Estados sempre aplicarão os princípios de intervenção humanitária seletivamente, ou seja, quando à ação de intervir 
mesmo sob a alegação humanitária servir aos interesses daquele Estado ou grupo de Estados. A menos que interesses vitais estejam em jogo, os Estados não irão intervir, portanto, o melhor que se poderia esperar da real motivação para uma intervenção humanitária seria a feliz coincidência entre a promoção do interesse nacional, em termos de segurança nacional, por exemplo, e a defesa dos direitos humanos. (WHEELER, 2000, p. 30)

A terceira objeção se refere ao problema do abuso do recurso às intervenções humanitárias, caso o direito à intervenção fosse legalizado. Tendo em vista que as preocupações humanitárias sempre ocultam a satisfação do interesse nacional, os Estados manipulariam tais preocupações fazendo com que uma possível doutrina da intervenção humanitária se tornasse uma arma que os fortes usariam contra os fracos. O problema do abuso corrobora a visão realista de que a linguagem é retórica, ou seja, é um disfarce público que mascara as reais razões de agir dos Estados.

A última objeção realista às intervenções humanitárias tem óbvia relação com o que Morgenthau chamou de 'dever oficial' do Estado. Segundo esse 'dever oficial', os Estados não devem e não têm que arriscar a vida de seus soldados ou de seu pessoal não-militar para salvar a vida de indivíduos que não sejam seus cidadãos nacionais. O Estado nacional, sob essa perspectiva, tem obrigações e deveres somente para com seus cidadãos, sem ter obrigação de cessar barbáries além de suas fronteiras. Assim sendo, a única justificativa racional de um Estado para arriscar a vida de seus soldados em situações de uso da força externamente a seu território seria a defesa de seu interesse nacional.

As quatro objeções realistas apresentadas acima compõem, junto com a objeção pluralista, o grupo das objeções às intervenções humanitárias denominado de consequencialismo. O consequencialismo se define pela oposição às intervenções humanitárias como o resultado das conseqüências negativas que elas podem geram. Passemos, portanto, a objeção consequencialista do pluralismo às intervenções humanitárias.

\subsection{A objeção pluralista às intervenções humanitárias}

A grande objeção pluralista às intervenções humanitárias baseia-se na preocupação de que na ausência de um consenso internacional sobre as regras que governam a prática da intervenção humanitária unilateral, os Estados agirão segundo seus próprios princípios 
morais, enfraquecendo a ordem internacional construída sob as regras de não-intervenção e não-uso da força.

Hedley Bull em A Sociedade Anárquica discute a relação entre ordem e justiça a partir da investigação de três grandes questionamentos: quais seriam os efeitos sobre a ordem internacional dada a tentativa de realizar as várias idéias de justiça? A justiça só pode ser alcançada na política mundial colocando em risco a ordem internacional? E se esse for o caso, a ordem ou a justiça deveria ter prioridade?

A opção de Bull é adotar a visão progressista ou liberal para conduzir o debate sobre esses três questionamentos. Nesse sentido, a premissa é que não há necessariamente um conflito entre ordem e justiça na política mundial, uma vez que as demandas para a preservação da ordem e para a promoção de uma mudança justa na política mundial não são mutuamente excludentes e que condições para reconciliar esses dois objetivos.

"Any regime that provides order in world politics will need to appease demands for just change, at least to some degree, if it is to endure; and thus an enlightened pursuit of the goal of order will take account also of the demand for justice. Likewise the demand for just change will need to take account of the goal of order; for it is only if the changes that are effected can be incorporated in some regimes that provides order, that they can be made secure”. (BULL, 2002, p. 91)

Mesmo nos casos em que há consenso de todas as partes envolvidas, mas há evidência decisiva de um consenso na sociedade internacional como um todo em favor de uma mudança que se acredita ser justa, especialmente se o consenso envolve todas as grandes potências, a mudança pode ocorrer sem causar mais do que um desordem local e temporária, depois da qual a ordem internacional como um todo aparecerá incólume ou mesmo numa posição mais forte do que antes. Segundo Bull, é de esperar que uma sociedade internacional que tenha alcançado o consenso não meramente sobre ordem, mas também sobre o alcance das noções de justiça internacional, humana e talvez mundial esteja numa posição mais forte para manter a estrutura de um mínimo de ordem ou coexistência do que uma sociedade que não tenha conseguido o mesmo.

A questão de conflito estaria, portanto, na ausência de consenso sobre o que a justiça envolve, assim como da possibilidade de que as reivindicações por justiça reabram questões que o pacto de coexistência requer que estejam fechadas. Nesse sentido, Bull discute a questão da prioridade entre ordem e justiça. Segundo o próprio Bull, ele evita dar uma 
definição persuasiva de ordem que prejulgaria a questão do valor da ordem como um objetivo humano. Por outro lado, ele afirma que a ordem é desejável ou valiosa nas relações humanas e e, a fortiori, também na política mundial.

Sendo a ordem desejável porque é a condição para a realização de outros valores, existe a percepção de que ela é prioritária em relação aos outros valores, como a justiça. Apesar disso, Bull ressalva que isso não significará que a ordem será em todo e qualquer caso prioritária à justiça, uma vez que a questão de ordem versus justiça será sempre considerada pelas partes em questão em relação aos méritos de um caso em particular.

Bull reforça esse argumento ao afirmar que, na ausência de um consenso dentro das Nações Unidas, incluindo todas as grandes potências, “(...) demands for external military intervention imply the subordination of order to considerations of international and human justice”. (BULL, 2002, p. 92) Portanto, Bull reconhece que, em alguns casos, a justiça pode ser prioritária à ordem, embora ele não considere essa alternativa como a mais apropriada, pelo menos no caso das intervenções humanitárias.

Quando se trata dessa questão, Bull enfatiza os perigos de tal prática para a ordem internacional, dado que os Estados têm concepções de justiça conflitantes. Seu argumento é de que embora a sociedade de Estados possa conceber a excepcionalidade dos casos específicos de intervenções humanitárias, não é possível pensar num direito de intervenção humanitária devido à relutância da sociedade internacional em comprometer as normas de não-intervenção e não-uso da força pela concessão de tal direito a Estados individuais, que dele poderiam se valer para justificar intervenções unilaterais.

A abordagem pluralista de Robert Jackson, em The Global Covenant, corrobora - pela oposição da ética clássica negativa à ética positiva das intervenções humanitárias - as idéias pluralistas, assim como a objeção pluralista apresentada por Hedley Bull a essas intervenções. De um lado, estaria a ética clássica das intervenções como ética negativa, baseada na imunidade constitucional do Estado soberano e, conseqüentemente, no seu direito fundamental de não-intervenção. Por outro lado, estaria a ética positiva de uma doutrina da intervenção humanitária, na qual os direitos humanos substituem a soberania estatal como a consideração normativa primária e decisiva na decisão de intervir.

No caso de vitória da ética positiva das intervenções humanitárias na política mundial, os Estados deixariam de estar (normativamente protegidos) por sua soberania e deixariam de 
ter o direito peremptório de não-intervenção. Contudo, ainda estamos inseridos em um contexto no qual as intervenções justificadas pelo humanitarismo são bastante controversas, em especial àquelas conduzidas unilateralmente.

Recorrer ao humanitarismo enquanto justificativa para intervir é controverso, segundo Jackson porque não requer consentimento do Estado alvo da intervenção e porque parece ir além dos princípios da Carta da ONU que se referem à paz e segurança internacionais e à auto-defesa legítima. A Carta da ONU embora proclame os direitos humanos como um objetivo da Organização, não inclui tais como uma base específica para a intervenção internacional na soberania estatal.

Em uma sociedade internacional pluralista, a não-intervenção é a norma e os atos de intervenção é que devem ser justificados. A intervenção é vista como ação internacional excepcional, pois os Estados soberanos têm o direito de ter suas jurisdições respeitadas por todos os outros e pela sociedade internacional, do mesmo modo que eles têm também o dever correspondente de respeitar esse direito a menos que existam razões válidas para justificar uma exceção à regra.

Até o momento, buscou-se traçar as origens do ceticismo moral nas relações internacionais que remontam ao estado de natureza hobbesiano com o objetivo de demonstrar em que medida as objeções realistas e a objeção pluralista às intervenções humanitárias foram influenciadas ou definidas pela ausência de um lugar da moralidade nas relações internacionais e na prática política internacional. Portanto, a partir da próxima seção serão analisados três casos empíricos de intervenção unilateral na década de 1970.

O que se pretende com a mobilização desses casos empíricos é analisar qual o peso e o papel dessas objeções, tanto realistas quanto pluralistas, baseadas no ceticismo moral das relações internacionais, para que essas intervenções que poderiam ter sido consideradas e justificadas sob argumento humanitário tenham sido duramente criticadas e mal-vistas pela sociedade internacional.

\subsection{Ordem versus iustiça na intervenção indiana de 1971: a estréia dos motivos humanitários e a prevalência da ordem}

Entre os meses de março e dezembro do ano de 1971, a repressão brutal do governo paquistanês ao povo bengali que vivia no leste do Paquistão resultou na morte de milhões de 
bengalis até que a intervenção unilateral da Índia cessou os massacres e levou a criação do novo Estado de Bangladesh. A ação militar indiana teve como principal motivação a crise interna gerada pelos refugiados bengalis que fugiam do massacre no leste do Paquistão em busca de segurança na Índia. A situação dos refugiados produziu um clamor público na Índia para que o exército interviesse no território que o governo indiano nomeou como "East Bengal”.

Ainda que existisse um forte consenso na sociedade internacional de que o conflito no leste do Paquistão era coberto pelo Artigo 2 (7), o conflito também começou a tornar-se uma crise internacional com a fuga dos refugiados para a Índia, possibilitando que o governo indiano justificasse a resposta militar da Índia com base na regra da auto-defesa do Artigo 51 da Carta da ONU. No entanto, a Índia considerou que o Artigo 51 era uma justificativa pública fraca para o uso da força, já que isso requereria que o uso da força fosse proporcional ao ataque inicial, uma condição da legítima defesa que não foi observada pela ação indiana.

A escolha indiana, por sua vez, foi alegar que o Paquistão havia cometido um crime de 'refugee aggression', na tentativa de persuadir o Conselho de Segurança de que o uso da força era uma resposta legítima à 'refugee aggression' e a agressão militar do Paquistão, que havia bombardeado bases aéreas indianas. Apesar de ter recorrido primariamente à justificação de autodefesa, tendo como base a 'refugee aggression', a Índia também evocou argumentos humanitários para justificar o uso da força.

De modo geral, a ação indiana foi vista amplamente como uma quebra das principais leis internacionais, colocando em risco os pilares da ordem internacional pluralista. Os EUA e a China rejeitaram as justificativas indianas para recorrer à força, alegando clara violação da Carta da ONU. Somente a União Soviética e a Polônia toleraram a ação indiana, com base na 'refugee aggression', no argumento de autodeterminação dos bengalis e na implícita alegação de intervenção humanitária.

Diante dos assassinatos em massa no leste do Paquistão, a reação da sociedade dos Estados foi de afirmar o direito do Paquistão à soberania e a regra da não-intervenção. A discussão na Assembléia Geral para chegar a resolução 2793 revela pouco ou nenhum apoio para a prática da intervenção humanitária na sociedade de Estados, dada a aprovação de um cessar-fogo imediato, por 104 votos a 11 com 10 abstenções. Nas palavras de Wheeler, a 
Assembléia Geral da ONU optou, nesse caso, por legitimar a posição que deixaria o exército paquistanês livre para continuar a repressão aos bengalis.

"The importance of the speech acts in Assembly is that they reproduced the inter-subjective understandings that constitute a pluralist society of states. The claims of justice were raised in debate, but Resolution 2793 secured such overwhelming support because it was accepted as a given that, even in cases of mass murder, there could be no exceptions to the constitutive rules of a pluralist international society”. (WHEELER, 2000, p. 69)

O fato de que a ação da Índia era considerada como uma ameaça à integridade territorial e independência política do Paquistão produziu a grande maioria que apoiou a resolução 2793 e apelou ao CS que evitasse o precedente que poderia erodir as bases da ordem na sociedade internacional. Em dezembro de 1971, o CS aprovou a Resolução 307 convocando um novo cessar-fogo, com retirada das forças armadas e uma ação para trazer os refugiados de volta a seu território de origem. No entanto, em campo o exército indiano já havia vencido o exército paquistanês e criado o novo Estado de Bangladesh. A nãocondenação da Índia pela resolução 307 é suficiente para que Fernando Teson e Gary Klintworth sustentem o surgimento de uma doutrina da intervenção humanitária na sociedade de estados, já que a ação indiana foi tratada com leniência porque foi vista como sendo uma ação por razões humanitárias.

O contra-argumento de Wheeler destaca o problema metodológico do argumento de Teson e Klintworth, pois entende que ambos sucumbem à falácia positivista de avaliar a legitimidade de uma prática normativa pelo estudo de um comportamento observável e evidente. O fato que a Índia não foi condenada pela Assembléia Geral, e que, com a exceção dos EUA, os governos não lhe impuseram sanções não deveria ser interpretado como uma evidência da legitimidade da intervenção humanitária na sociedade de estados, segundo ele. Dessa maneira, seria um erro considerar uma forma de atenuação legal como aprovação moral e reconhecimento dos argumentos humanitários utilizados como base legítima para o uso da força.

Não se pode deixar de mencionar que o contexto da intervenção indiana era a Guerra Fria, com EUA e China alinhados ao Paquistão e a União Soviética apoiando a Índia. Esse contexto foi determinante para a não-discussão do caso pelos principais poderes e pela recusa do CS de dar aprovação a uma ação multilateral de intervenção no Paquistão sob o capítulo VII da Carta, que permite que o Conselho ultrapasse a proibição de uma intervenção da ONU 
no Artigo 2 (7). O então Secretário-Geral da ONU, U Thant, apresentou um memorando oficial ao CS em julho (tornado público em agosto) dizendo que o conflito interno no leste do Paquistão poderia facilmente escalar para uma guerra no subcontinente, e que era responsabilidade do CS prevenir esse acontecimento, o que, contudo, não foi feito.

Tendo em vista a falha do CS em cessar as violações em massa dos direitos humanos e a situação de grande sofrimento dos refugiados na fronteira entre os dois países, a intervenção armada indiana poderia ser justificada como intervenção humanitária se ela tivesse sido justificada sob a doutrina da intervenção humanitária. A falha da ONU e da sociedade internacional como um todo de responder às demandas humanitárias do povo bengali, segundo Wheeler, deu à Índia o direito legal de intervir unilateralmente. O fato da Índia justificar o uso da força unilateralmente em bases humanitárias pela primeira vez é o que torna essa intervenção um marco, já que foi a partir de então que se criou uma oportunidade para o CS rever a prioridade usual da ordem sobre a justiça acordada entre os Estados na sociedade internacional.

Apesar do discurso dominante no Conselho de Segurança e na Assembléia Geral ser o pluralista, o realismo também empregou seus argumentos para interpretar o caso indiano. Sob a interpretação realista, a defesa das regras pluralistas pelos EUA e pelos chineses pode ser explicada pelo interesse geopolítico de ambos em apoiar o Paquistão contra a Índia, aliada da URSS. Por outro lado, a vitória da Índia abriria a possibilidade de que a URSS controlasse o novo Estado de Bangladesh, e o mais importante, desse a Moscou uma vantagem importante na competição geopolítica contra a China e os EUA.

O problema com esse argumento realista é que mesmo diante da concepção dominante no CS de que a justiça teria que ser subordinada à ordem, a URSS defendeu a contrariedade dessa posição, alegando que não poderia haver ordem sem a satisfação das demandas por justiça. Sejam quais fossem os motivos ocultos na posição soviética, o fato é que a URSS desafiou o consenso intersubjetivo existente no CS e na AG. A complexidade da ação soviética, que não se restringe ao cálculo retórico restrito dos realistas, assenta-se na idéia de que a linguagem, mesmo sendo usada estrategicamente, é a única possibilidade para alcançar um acordo, já que é a oportunidade aberta para que os atores mudem o entendimento de seus interesses por meio da argumentação. 
No caso soviético, o argumento de que a ordem teria melhor suporte pela oposição ao cessar-fogo e não por sua aprovação como aconteceu, enfrentaria de qualquer forma a oposição dos adversários alinhados aos EUA. No entanto, esse argumento falhou em não conseguir apoio entre os Estados não-alinhados, uma vez que estes também o consideravam como subversivo às regras pluralistas de manutenção da ordem internacional.

O segundo problema em ver a linguagem somente pela ótica estratégica como fazem os realistas é que isso esconde o poder do discurso para constranger a escolha dos agentes, bem como desconsidera que a estratégia é produto de um senso prático, e não de projetos ou cálculos conscientes e racionais. No caso indiano, a resposta internacional ao uso do argumento humanitário para justificar o uso da força poderia ter constrangido a escolha dos demais Estados caso existisse suporte para isso naquele contexto, ou seja, caso os membros da ONU pudessem ser capazes de questionar as regras pluralistas da soberania, não-intervenção, e não-uso da força, constituintes do espaço no qual uma argumentação legítima poderia acontecer.

A intervenção humanitária, pela teoria pluralista da sociedade internacional, definida como uma ameaça às normas de soberania, não-intervenção, e não-uso da força foi justamente a interpretação dominante na prática dos Estados durante o caso Bangladesh. Apesar disso, foi a primeira vez na sociedade internacional pós-1945 que argumentos humanitários foram levantados para justificar o uso da força.

\subsection{A intervenção do Vietnã no Camboja: mais um 'triunfo’ da ordem sobre a justiça?}

O conflito entre os vietnamitas e o povo khmer se arrastava por séculos e teve no conflito entre o Camboja e o Vietnã nos anos de 1978 e 1979 mais um capítulo nessa longa história. Logo após o Khmer vermelho ter assumido o poder em 1975 foram registrados inúmeros conflitos na fronteira com o Vietnã. O regime de Pol Pot tinha um verdadeiro fanatismo por recuperar os territórios do Delta Mekong e a área ao redor de Saigon, considerados territórios do velho império Khmer perdidos à força para os vietnamitas. A estratégia do Khmer vermelho foi manipular o tradicional medo do povo Khmer sob a afirmação de que o Vietnã tinha um plano para conquistar a Campuchéia (Kampuchea) - 
antigo Camboja - e que isso poderia ser evitado somente com a aniquilação dos vietnamitas, dando origem a todo o conflito.

Os conflitos entre o Vietnã e o Camboja iniciados na fronteira evoluíram até a intervenção vietnamita no Camboja em 1979, derrubando o regime de Pol Pot. Embora o Vietnã pudesse ter tentado justificar seu uso da força em bases humanitárias, a opção foi por não utilizar esse argumento. O Vietnã entendia que havia duas guerras em curso: uma na fronteira entre os dois países, iniciada pelas forças de Pol Pot, e outra interna, uma guerra revolucionária do povo cambojano. Sendo assim, o governo vietnamita escolheu defender que seu recurso à força estava restrito ao exercício do sagrado direito dos povos de autodefesa frente a uma agressão.

Dentre os motivos que podem explicar porque o Vietnã recusou-se a justificar sua ação sob o argumento de intervenção humanitária, está o fato de que o Vietnã pode simplesmente ter aceitado a legitimidade das regras da soberania, não-intervenção e não-uso da força. O argumento das duas guerras é bastante indicativo do forte desejo vietnamita de legitimar suas ações em termos das regras aceitas. Outro motivo é que o Vietnã pode ter considerado que a alegação de uma intervenção humanitária faltaria em credibilidade, dado o silêncio em relação à questão da violação dos direitos humanos durante os primeiros quatro anos do regime de Pol Pot. E, finalmente, é possível que os vietnamitas temessem estabelecer um precedente para a intervenção humanitária que poderia ser usado por outros Estados para atacar o Vietnã ou seus aliados no futuro.

Apesar da presença de mais de 100.000 soldados vietnamitas dentro do Camboja, os representantes do Vietnã na ONU até tentaram persuadir o CS de que a derrubada do Khmer vermelho tinha sido alcançado pelas forças de guerrilha do Fronte de Salvação Nacional, junto com um levante do povo cambojano. Esse posicionamento e justificativa do Vietnã foram tomados como falsos e fizeram com que esse país pagasse um alto preço econômico e político por sua decisão de agir.

A resposta hostil à intervenção vietnamita emanou de três grupos de atores: os EUA e seus aliados, que interpretaram a ação do Vietnã como um movimento dentro do jogo da política de poder da Guerra Fria; a ASEAN, que temia que o uso da força do Vietnã contra o Camboja teria como herança o início da expansão do Vietnã em direção à hegemonia 
regional; e os Estados neutros e não-alinhados, que tinham a preocupação de que a ação do Vietnã colocasse em risco as regras da lei nas relações internacionais.

Os EUA usaram considerações pluralistas, alegando que os direitos humanos não poderiam justificar uma quebra das regras de não-intervenção, integridade territorial e nãouso da força para defender que o Vietnã retirasse imediatamente suas forças e respeitasse a integridade territorial do Estado cambojano. A administração Carter procurou elevar os direitos humanos na hierarquia dos princípios da política externa, mas, quando veio a escolha entre sustentar o Estado de Direito ou permitir uma exceção em nome de resgatar o povo cambojano, uma interpretação absolutista das leis e dos princípios pluralistas venceu.

A resposta positiva à ação do Vietnã por parte das vítimas do Khmer vermelho colocase em agudo contraste com a resposta internacional hostil que a mesma ação recebeu. Não existe nenhuma dúvida de que o caso dos campos de extermínio do Camboja representava um caso de grave violação dos direitos humanos e que a intervenção militar externa era o único modo de cessar as barbáries do regime de Pol Pot.

\footnotetext{
"The lesson of Cambodia is...whose security? That of Pol Pot? Or of China and the United States against the security - that is, the lives - of Cambodians? To claim that the sanctity of frontiers (as breached by Vietnamese) should have priority over the safety of thousands of Cambodians represents an appalling 'reversal of values"”. (GIRLING apud WHEELER, 2000, p. 110)
}

A relevância do caso do Camboja está em que a intervenção humanitária como uma alternativa moral prática já estava presente nos discursos dos Estados, mas as regras pluralistas que constituíam (e ainda constituem) os dados do discurso tornaram impensável legitimar a ação do Vietnã como humanitária e ainda impuseram uma dura sanção a este país (com exceção da URSS e de seus aliados comunistas) por quebrar as leis de soberania, nãointervenção e não-uso da força.

\subsection{A intervenção da Tanzânia em Uganda: o problema do silêncio e da seletividade}

As relações entre Tanzânia e Uganda se deterioraram ao longo dos anos 1970 e em outubro de 1978 a Uganda invadiu a Tanzânia, dando a oportunidade à Tanzânia de contra- 
atacar e derrubar o governo bárbaro do ditador Idi Amin em abril de 1979. Depois de chegar ao poder em 1971, Idi Amin impôs uma ditadura de 8 anos à Uganda, que, segundo a Anistia Internacional, matou mais de 300.000 pessoas.

O uso da força da Tanzânia contra Uganda no início de 1979 removeu esse regime bárbaro que havia tornado-se um embaraço para os outros governos africanos, apesar da falha desses governos em condenar o grotesco comportamento de Amin para com seus cidadãos, valendo-se das prerrogativas do Artigo III da OAU (Organization of African Unity/Organização da Unidade Africana), que proíbe qualquer intervenção nas relações internas de um Estado-membro.

A única exceção ao silêncio geral dos países africanos foi o Presidente da Tanzânia, Julius Nyerere, que condenou os abusos de Amin e desafiou a legitimidade dessa regra. Nyerere estava escandalizado com o fato de que ele era o único líder africano a condenar os abusos de Amin aos direitos humanos, acreditando que os princípios da OAU deveriam salvaguardar tanto a justiça quanto a ordem. Ele defendeu sua posição frente aos seus ministros em 1975 da seguinte forma:

“(...) when massacres, oppression and torture are used against Africans in the independent states of Africa there is no protest anywhere in Africa.(...) It is made to appear that Africans lose their right to protest against state-organized brutality on the day that their country becomes independent through their efforts. For on all such matters the OUA acts like a trade union of the current heads of State and Government, with solidarity reflected in silence if not in open support for each other”. (WELCH, 2000, p. 113) ${ }^{23}$

O Presidente da Tanzânia explicitamente clamava por uma mudança nas regras que deveriam negar a proteção da carta da OAU para aqueles governos que cometessem abusos em massa dos direitos humanos internamente. Nyerere queria a condenação do regime de Amin por parte da OAU, mas sabia que a organização não faria tal condenação e que a negativa dele em aceitar os esforços da mesma para resolver o conflito tornaria muito difícil que ele justificasse seu uso da força contra a Uganda em bases humanitárias.

\footnotetext{
${ }^{23}$ Conferir em WELCH. “The OUA and Human Rights: Towards a New Definition”. Journal of Modern African Studies, 19/3 (1981), 405
} 
Além disso, embora ele estivesse lutando por uma mudança na carta da Organização que não protegesse tiranos como Amin, ao mesmo tempo ele não estava preparado para alegar que profundos abusos dos direitos humanos legitimavam intervenções armadas por parte de Estados externos. Ele rejeitava a doutrina da intervenção humanitária unilateral já que afirmava a ilegitimidade de usar a força para derrubar um regime assassino como o de Amin. Sem contar que ele nunca teve a intenção de que suas forças avançassem profundamente nos territórios de Uganda.

Para legitimar seu uso da força, Nyerere recorreu ao argumento das duas guerras que o Vietnã já havia usado e foi ridicularizado no CS. O problema é que a esperança inicial de Nyerere era de que as suas forças poderiam ficar confinadas às áreas de fronteira o que acabou não acontecendo, pois elas foram obrigadas a avançar nos territórios da Uganda, possibilitando a ridicularização da teoria das duas guerras por parte dos Estados ocidentais.

O silencio com relação ao conflito Tanzânia-Uganda parece não ter ficado restrito aos Estados africanos, pois nunca foi debatido nem pelo Conselho de Segurança nem pela Assembléia Geral. Um dos motivos era a falta de apoio dos Estados africanos na ONU para que o CS ouvisse o caso de Uganda, bem como porque Uganda nunca foi vista pelo Conselho como a parte ofendida. Além disso, enquanto o CS foi a arena em que os grandes poderes rivalizaram em relação ao uso da força do Vietnã contra o Camboja, a ação da Tanzânia não foi considerada no conflito geopolítico entre os grandes poderes.

Os Estados ocidentais reagiram cautelosamente à remoção forçada de Amin pela Tanzânia, nem louvando nem oferecendo qualquer comentário direto sobre a legitimidade desse uso da força. Segundo a perspectiva dos Estados ocidentais, a diferença chave entre os dois casos era de que o Vietnã era um Estado expansionista, agindo em favor do expansionismo soviético, enquanto a Tanzânia tinha sido provocada e não era um estado predador. Wheeler apresenta dois problemas para tal argumento: o primeiro diz respeito a desconsideração do fato de que o Vietnã foi provocado pelo regime de Pol Pot. O segundo problema é que a intervenção do Vietnã foi julgada somente a partir de considerações sobre os motivos expansionistas para a intervenção; argumento que na verdade não consegue encobrir a falha dos Estados ocidentais em responder por que a ação da Tanzânia não foi igualmente considerada como desafio à estrutura legal da sociedade internacional. (WHEELER, 2000, p. 124) 
Em comparação com o caso do Vietnã, a conclusão é de que os argumentos doutrinários usados contra o Vietnã foram convenientemente esquecidos pelos Estados ocidentais no caso da Tanzânia. Desse modo, a questão da seletividade na aplicação dos princípios, uma das principais objeções realista a intervenção humanitária surge a partir dessa comparação. Não obstante, o caráter humanitário da ação da Tanzânia daria legitimidade para considerá-la uma intervenção humanitária.

O fato de nenhum embargo ter sido aplicado à Tanzânia, e dos Estados membros da ONU não terem manifestado a desaprovação diante desse caso, não torna plausível o argumento de que a intervenção da Tanzânia estabeleceu um importante precedente para a intervenção humanitária no direito internacional costumeiro. Primeiro porque o uso da força da Tanzânia só se tornou possível porque Uganda atacou primeiro, o que legitimaria uma ação em legítima defesa; segundo porque, com exceção do novo governo de Uganda, nenhum outro Estado legitimou o uso da força da Tanzânia em bases humanitárias.

Para que o caso da Tanzânia confirmasse o argumento de uma nova regra no direito internacional costumeiro com relação às intervenções humanitárias, o argumento moral dos Estados líderes em relação a isso deveria ser evidente. De acordo com Wheeler, para que uma regra legal de intervenção humanitária seja desenvolvida, deve haver uma nova prática em curso e opinio juris, isto é, que a vasta maioria dos Estados argumente que a nova prática é permitida ou requerida pela lei. (WHEELER, 2000, p. 135)

\section{9. É possível falar em intervenções humanitárias durante a Guerra Fria?}

Considerando as ações da União Soviética sobre a Europa Oriental e as ações da ONU no conflito Israel-Palestina do Oriente Médio, a história da Guerra Fria poderia dar a impressão de que a política internacional era predominantemente uma atividade de intervenção ao invés de respeito à norma da não-intervenção. No entanto, o oposto é que é o mais próximo da realidade, já que fora de suas zonas de confrontação tanto a União Soviética quanto os Estados Unidos em geral respeitaram a norma da não-intervenção.

Na África, por exemplo, cada uma das superpotências estava consciente da importância de respeitar o princípio das fronteiras ex-coloniais que eram as bases da ordem internacional no continente. Aliás, a típica base normativa das intervenções nos países 
considerados de Terceiro Mundo durante a Guerra Fria foi a solicitação do próprio Estado que iria receber a intervenção. Os casos de intervenção da União Soviética na Etiópia e Angola, assim como das intervenções dos EUA no Líbano, na República Dominicana e no sul do Vietnã ocorreram nessas bases.

Tendo em vista que de forma geral o consentimento era a base das intervenções durante a Guerra Fria, no caso das atividades humanitárias isso não foi diferente. A ação das ONGs internacionais de direitos humanos para ajudar os etíopes em meados da década de 1980 é um bom exemplo. As ONGs só puderem atuar no país após conseguirem a permissão de Mengistu Haile Mariam, ditador militar da Etiópia, antes que os alimentos pudessem ser distribuídos aos etíopes em processo de inanição.

O processo de descolonização é de suma importância para entender as características desse período, uma vez que inúmeros estados fracos nasceram desse processo e criaram um escopo operacional ampliado para a norma da não-intervenção. Uma observação interessante de Jackson é que os líderes dos Estados fracos não eram contra a intervenção, já que eles sabiam que eles poderiam chamar outros Estados de tempos em tempos para a assistência militar. Esses Estados eram contrários a intervenção sem consentimento. Portanto, a nãointervenção (liberdade negativa) e em particular o princípio de consentimento foram as normas favorecidas pelos Estados mais fracos do sistema que tinham somente no Direito Internacional e na opinião pública a salvaguarda de suas independências.

Como vimos acima, a intervenção indiana no Paquistão em 1971, a intervenção do Vietnã no Camboja em 1978-9 e a intervenção da Tanzânia em Uganda em 1978, embora possam ser tratados como possíveis intervenções humanitárias ou instâncias de intervenção humanitária, segundo Jackson, foram justificadas por seus líderes sob a base da defesa própria. A interpretação pluralista é de que a oportunidade política de tornar o humanitarismo armado um possível curso de ação que fosse considerado legítimo pelo Conselho de Segurança e pela sociedade internacional não estava disponível naquele contexto. (JACKSON, 2000, p. 259)

O motivo para que o argumento humanitário fosse preterido em nome do princípio convencionalmente acordado da legítima defesa nos três casos está na própria Guerra Fria, quando "there was no singular organized will and capacity for international armed intervention during the period; instead there were conflicting superpower wills that 
checkmated each other and thereby blocked armed internationalism for humanitarian or any other purposes”. (JACKSON, 2000, p. 259) A intervenção humanitária só se tornaria politicamente possível a partir de 1989, após o fim do conflito bipolar.

A interpretação solidarista de Nicholas Wheeler é bastante próxima da interpretação pluralista de Jackson no tocante à razão que fez com os governos preferissem valer-se das regras pluralistas, com a exceção inicial da Índia, para justificar suas ações de intervenção. Segundo Wheeler, o argumento humanitário que legitimamente poderia ter sido invocado para justificar o uso da força foi negligenciado por não se enquadrar dentro das fronteiras aceitáveis de uma ação permissível dentro do contexto de uma sociedade internacional pluralista.

Assim, embora as duas interpretações daquela 'realidade contextual' entendam que ao longo do século XX as bases para a intervenção humanitária legítima e legal por força armada (jus ad bellum) tenham sido restringidas pela sociedade internacional, há dois elementos que diferenciam enormemente essas duas perspectivas. O primeiro é o fato de que Wheeler entende que as intervenções de Índia, Vietnã e Tanzânia poderiam ter sido justificadas como humanitárias, apesar das imposições daquele contexto que fatalmente rejeitaria essa justificação sob novas bases normativas. (WHEELER, 2000)

O segundo elemento é o grande diferenciador das duas perspectivas. Como veremos no capítulo a seguir, os dois autores entendem que, diante da ocorrência significativa de intervenções humanitárias aprovadas e legitimadas pela ONU no final de século XX, as bases para legitimar (e legalizar, no caso solidarista) as intervenções humanitárias (mesmo as unilaterais, também sob a perspectiva solidarista) estavam sendo expandidas. E é justamente a interpretação dessa expansão que difere as duas perspectivas, já que Jackson continua entendendo que as intervenções humanitárias ou o humanitarismo, como ele prefere chamar, só podem ser realizados dentro da estrutura pluralista da sociedade internacional.

A defesa de que a ética dos direitos humanos e as intervenções humanitárias devem estar inseridas na estrutura pluralista da sociedade internacional corrobora as preocupações manifestadas pela objeção pluralista às intervenções e demonstra a rejeição de que a justiça possa ser prioritária à ordem num contexto de ampliação das aspirações normativas da sociedade internacional. 
Além do caráter consequencialista das objeções realistas e da objeção pluralista às intervenções humanitárias, essas duas perspectivas possuem em comum dois elementos de grande afinidade. O primeiro elemente é o papel e valor que o Estado soberano possui tanto para realistas quanto para pluralistas. É a inquestionabilidade do Estado e de suas prerrogativas, as quais remontam à equivocada analogia ao estado de natureza hobbesiano, que torna possível agregar numa linha de continuidades e similaridades as concepções realista e pluralista.

O que segue, portanto, da inquestionabilidade do Estado e de suas prerrogativas soberanas de decidir sobre a vida e morte de seus cidadãos sem interferência externa, bem como de defender sua própria concepção de bem, segundo o pluralismo, ou sua própria concepção de interesse, segundo o realismo, sem restrições, resulta na resolução do dilema entre ordem e justiça pela subordinação desta última à primeira. A justiça, entendida a partir dos direitos dos indivíduos, sem consideração de nacionalidade, não pode ser concebida, nesse espectro, como prioritária em relação à ordem.

Essas característas que aproximam as bases do pensamento pluralista às bases realistas indicam que a concepção de ordem e de sociedade internacional do pluralismo de Bull foram influenciadas pela concepção realista que compreende as relações internacionais a partir do estado de natureza hobbesiano. Apesar desse traço de continuidade entre realismo e pluralismo, vale enfatizar que a significativa contribuição de Hedley Bull ao considerar a existência de valores e interesses comuns em sua formulação da sociedade internacional foi determinante para a diferenciação e, em alguma medida, rompimento do pluralismo com o realismo.

A análise das intervenções da Índia (1971), Vietnã (1979) e Tanzânia demonstraram como as objeções realistas e a objeção pluralista às intervenções humanitárias foram determinantes para que os referidos casos não pudessem ser legitimados pela ONU, ou mesmo, justificados por motivos humanitários. Embora os discursos tenham evidenciado que a intervenção humanitária era uma alternativa moral prática diante das emergências humanitárias de cada um dos casos, o contexto de Guerra Fria fortaleceu as bases da ordem pluralista e a postura de defesa de seu princípio de soberania e das normas de não-intervenção e não-uso da força. O conflito político, ideológico e econômico entre as duas potências, EUA 
e URSS, baseado em áreas de influência que dividiam o mundo em pólos opositores e indicavam o pertencimento a um dos lados da disputa, exigia que as fronteiras fossem mais do que nunca intransponíveis, assim como requeria que o uso da força e da intervenção fossem estritamente observados para garantir o funcionamento da balança de poder bipolar.

No próximo capítulo, veremos como as intervenções da década de 1990 passaram a ser legitimadas como humitárias pela sociedade internacional a partir do término do conflito bipolar. A análise dos casos de intervenção humanitária na Somália (1992), Ruanda (1994) e Kosovo (1998) tem como objetivo analisar em que medida é possível considerar uma expansão das bases normativas da sociedade internacional, em direção a normas mais solidaristas, com relação ao fenômeno das intervenções humanitárias.

A investigação das possibilidades de considerar uma alteração do contexto normativo que legitima as intervenções humanitárias será realizada por meio de uma análise da importância e do papel das normas para a legitimidade internacional. Dessa maneira, as normas e os constrangimentos normativos que elas geram a ação dos Estados serão analisados com o objetivo de buscar os avanços e limites da proposta solidarista de Nicholas Wheeler (2000), baseada numa moralidade cosmopolita e na soberania como responsabilidade de proteger.

\section{CAPÍTULO III - AS INTERVENÇÕES HUMANITÁRIAS DA DÉCADA DE 1990: O QUANTO UMA POSSÍVEL “EXPANSÃO DA AMBIÇÃO NORMATIVA” PODE RECONCILIAR ORDEM E JUSTIÇA?}

O terceito e último capítulo desse trabalho pretende, por meio da análise dos três principais casos de intervenção humanitária da década de 1990: Somália (1992), Ruanda (1994) e Kosovo (1998), investigar em que medida é possível falar em uma "expansão da ambição normativa” com relação às tão polêmicas e controversas intervenções humanitárias. Mais ainda, a análise a seguir pretende indagar em que medida a proposta solidarista de legitimidade normativa das intervenções humanitárias pode significar uma proposta de reconciliação entre ordem e justiça. 
O principal objetivo desse capítulo é entender como foi possível que os Estados ocidentais invocassem os argumentos solidaristas para justificar suas intervenções nos anos 1990, quando foram os mesmos Estados que lideraram a condenação das intervenções da Índia e do Vietnã, que poderiam e deveriam ter sido legitimadas em bases humanitárias, nos anos 1970.

Nesse sentido, a apresentação de cada um desses casos não se pretende um convencional e detalhado estudo de caso, mas sim uma breve, porém ilustrativa apresentação de como os argumentos humanitários avançaram por meio dos Estados ocidentais desafiando os princípios de legitimidade pluralista dominantes da sociedade de Estados durante a década de 1990.

O argumento solidarista que entende a prática das intervenções humanitárias como ação legítima a partir de uma nova estrutura normativa que demonstra o poder das normas e o alcance da legitimidade proveniente dos constrangimentos normativos. A investigação dessa nova estrutura normativa procurará as possibilidades e os limites de uma norma de intervenção humanitária, mesmo daquelas intervenções que sequer são consideradas legítimas por não terem a aprovação da ONU. Essas intervenções humanitárias unilaterais são o ponto nevrálgico da proposta solidarista de Nicholas Wheeler, a base teórica para toda essa análise normativa.

\subsection{Intervenções humanitárias na década de 1990: rumo a uma 'expansão da ambição normativa' solidarista?}

\subsubsection{A força para aliviar a fome: a ONU e os EUA na Intervenção Humanitária da Somália}

O caso da Somália em 1992 é considerado o primeiro caso de intervenção humanitária nos termos definidos na Introdução deste trabalho. O uso da força, autorizado por resolução do CSNU foi aprovado, pela primeira vez, sob o Capítulo VII da CNU, estabelecendo a Operação Restore Hope, liderada pelos Estados Unidos. A intervenção na Somália inaugurou o que se convencionou chamar de "Era das Intervenções", demonstrando toda a complexidade de aplicar a força para aliviar a fome, em um território sem lei ou governo. 
Os Antecedentes da Intervenção ${ }^{24}$

A tragédia humanitária que se abateu sobre o povo somali nos anos de 1991 e 1992 foi o resultado de uma guerra civil e da subseqüente desintegração do Estado somali, após a queda do governo do ditador Mohammed Siad Barre, em 27 de janeiro de 1991. O então ditador havia governado o país com mãos de ferro desde os anos 1960 e controlado, por meio da manipulação das lealdades clânicas e do emprego da violência, o sistema de clãs e subclãs que compõe a Somália.

O que se esperava é que depois da queda de Barre um governo de reconciliação nacional fosse criado, mas o que se viu foi a formação de milícias armadas, a partir dos clãs e subclãs, que passaram a lutar pelo controle do poder, de determinados territórios do país. Qualquer esperança de que um governo central se formasse e restaurasse a autoridade institucional e legal do Estado somali desapareceu assim que, em novembro de 1991, os líderes do partido United Somali Congress (USC) dividiram-se em grupos opostos e iniciaram o conflito. Dissolvia-se, portanto, a aliança política que anteriormente havia sido a maior responsável pela queda de Barre, combatendo as forças do ditador na região central e na capital do país, Mogadishu.

A guerra civil pelo controle de recursos e terras entre as facções de subclãs rivais na Somália, iniciada no final de 1991, foi responsável pela devastação da produção agrícola e animal; por um verdadeiro colapso na distribuição de suprimentos emergenciais das agências humanitárias que já estavam no país, mesmo antes da queda de Barre; pela disseminação da fome; pelo deslocamento e refúgio de milhares de civis; e pela destruição da atividade econômica do país.

Enquanto os somalis encerravam o ano de 1991 sendo dizimados pela violência e pelas graves conseqüências diretas do conflito, como as mortes por inanição, a atenção do mundo estava voltada para o Oriente Médio e a Europa. A ONU, seus Estados membros, com especial atenção para os Estados Unidos, e a mídia internacional concentravam sua atenção e esforços na crise dos curdos no Iraque e na guerra que se desenvolvia na Bósnia.

\footnotetext{
${ }^{24}$ A breve descrição dos antecedentes da intervenção tem por objetivo apresentar, de forma geral, o contexto somali anterior à aprovação da Resolução 794, caracterizando a primeira intervenção humanitária aprovada pelo CS da ONU em 1992. A preocupação, portanto, é fornecer informações básicas a respeito do contexto do conflito, e da conseqüente situação de emergência humanitária, que permitam a posterior análise das proposições teóricas sobre o caso em questão. Para maior detalhamento ou aprofundamento das informações, consultar em: SILVA, 2003 e LYONS \& SAMATAR, 1995.
} 
O recrudescimento da violência entre os senhores da guerra na Somália atingiu seu pior período entre novembro de 1991 e março de 1992. Naquela ocasião, a escalada de violência tinha atingido tal gravidade que as agências humanitárias da ONU se retiraram do país temendo pela segurança de seu pessoal. No entanto, a piora do conflito, que até aquele momento era acompanhado somente pelo trabalho de agências humanitárias internacionais, como a Cruz Vermelha, adensou as críticas com relação ao papel das Nações Unidas perante o agravamento da situação na Somália.

Essas críticas levaram o então Secretário Geral, Boutros Boutros-Ghali, a estimular um maior envolvimento da Organização para solucionar aquela emergência humanitária. Esse envolvimento da ONU resultou na aprovação unânime da Resolução 733, adotada em 23 de janeiro de 1992. O documento autorizou um embargo de armas ${ }^{25}$, sob o Capítulo VII da Carta da ONU, a partir da declaração de que o conflito interno na Somália constituía uma ameaça à paz e à segurança internacionais. Como seguimento dessa resolução, as negociações entre as partes beligerantes geraram um acordo de cessar-fogo, assinado em 03 de março de 1992, numa reunião realizada em Nova York com as presenças de líderes da Organização da Conferência Islâmica, da Liga Árabe e da Organização da Unidade Africana.

A Resolução 733 ainda previa que o cessar-fogo não fosse endereçado somente para resolver a crise de inanição que exigia ações imediatas, mas também servisse como base para a criação de uma nova estrutura de autoridade civil, baseada no Estado de Direito. Essa recomendação, entretanto, não saiu do papel, pois não havia de fato interesse entre os membros do CS em ter um comprometimento amplo a fim de ajudar os somalis na construção da estabilidade política do país.

Apesar da aprovação de um cessar-fogo restrito, o acordo teve sua importância, já que ele representava a única possibilidade para que a ajuda humanitária finalmente chegasse a seu destino: os milhares de somalis que morriam por inanição. O cessar-fogo também resultou na aprovação da Resolução 751, em março de 1992, pelo Conselho de Segurança, que previa uma Operação das Nações Unidas para a Somália (UNOSOM - sigla em inglês) e o envio 500 capacetes azuis, oferecidos pelo Paquistão, que deveriam compor uma força de segurança, além de 50 observadores responsáveis por zelar pela implementação do acordo.

\footnotetext{
${ }^{25}$ Wheeler observa que a adoção de um embargo de armas como primeira medida estabelecida pela Resolução 733 foi uma medida irônica, dado que os clãs da Somália estavam fortemente armados durante o conflito justamente por anos de Guerra Fria em que as superpotências - EUA e URSS - forneciam armas para a Somália. (WHEELER, 2000, p. 175)
} 
Não obstante, mesmo após a assinatura do cessar-fogo entre as duas principais milícias, os saques e extorsões cometidos por gangues armadas, que estavam fora do controle dos líderes dos clãs continuaram. Essas gangues extorquiam as agências de ajuda humanitária, exigindo pagamentos em dinheiro e parte dos suprimentos que deveriam ser entregues à população faminta em troca da proteção contra ataques ao seu pessoal. Assim, as mortes de centenas de milhares de somalis não ocorreram por falta de ajuda humanitária, mas pela falta de condições mínimas de segurança para que a ajuda fosse rapidamente distribuída. Na capital do país, Mogadishu, e também no interior, o que prevalecia era a ausência crônica da lei. ${ }^{26}$

A expectativa de resultados mais rápidos por parte do Secretário Geral das Nações Unidas contribuiu para que o Conselho de Segurança aprovasse, no final de agosto de 1992, a resolução 775, que autorizou o emprego de uma tropa de 3.500 soldados sob forma de operação de manutenção da paz a fim de proteger a entrega de ajuda humanitária.

A decisão de enviar os capacetes azuis da ONU em missão de manutenção da paz para a Somália, sem o consentimento dos líderes somalis, acabou sendo negativa para a principal intenção do envio das tropas - a distribuição da ajuda humanitária. O descontentamento dos líderes dos clãs com a decisão da ONU e o fato dos capacetes azuis, destacados pela ONU para a Operação das Nações Unidas para a Somália I - UNOSOM I, sigla em inglês - não terem um mandato que permitia o uso da força - embora a resolução tivesse sido aprovada sob o capítulo VII da Carta - tornou ainda mais difícil a entrega de ajuda humanitária para a população civil somali e transformou os soldados em alvos fáceis para os ataques dos rebeldes.

Vale destacar que a decisão do CS de empregar as tropas da UNOSOM I, sem o consentimento das partes em conflito, representou uma mudança significativa em relação à estratégia de negociação com as milícias armadas que estavam bloqueando os esforços de ajuda humanitária. O abandono da estratégia de negociação do representante especial da ONU, Mohamed Sahnoun ${ }^{27}$, e a adoção de tropas significavam que a prerrogativa para usar a força a fim de entregar a ajuda humanitária estava lançada. A questão, contudo, era que nenhuma força seria capaz de implementar um mandato tão ambicioso, frente à enorme complexidade do conflito no território somali. (WHEELER, 2000, p. 178)

\footnotetext{
${ }^{26}$ Estima-se que, durante 1992, entre 330 a 350 mil civis tenham morrido por inanição na Somália. Conferir em: WHEELER, 2000, p. 174.

${ }^{27}$ A atuação do enviado especial da ONU, assim como seus esforços para a resolução do conflito, por meio de negociações será discutida nos apontamentos finais do caso somali, quando a análise se voltará para a aplicação dos requisitos que conferem legitimidade à uma intervenção humanitária, como o princípio de recorrer à força como último recurso.
} 


\section{A Operação Restore Hope}

A situação na Somália parecia incontornável até que o telegrama do embaixador americano no Quênia, descrevendo a situação de inanição dos refugiados somalis nos campos ao longo da fronteira com o Quênia, chegou à imprensa americana e despertou o interesse de toda a mídia internacional. Era o claro resultado do chamado "efeito CNN". "The thesis of the so-called 'CNN factor' holds that the US government can be propelled into foreign adventures on the basis of active but selective attention to particular crises by the main US media”. (THAKUR, 2006, p. 55) Finalmente, os olhos do Ocidente se abriam espantados diante daquela realidade, na qual mais de 1.000 somalis morriam diariamente. A cobertura da mídia internacional, liderada pela mídia americana, havia transmitido para o mundo todo, as imagens e fotos do sofrimento do povo somali, causando comoção, indignação e pressão para que alguma providência fosse tomada diante do caso.

Não era só o sofrimento dos civis somalis que ficava evidente aos olhos da opinião pública internacional, em especial da norte-americana, a impossibilidade das tropas da ONU de conter o agravamento da violência, cessar o conflito, distribuir a ajuda humanitária e, assim, evitar a morte de um número ainda maior de somalis também era evidente. Tal evidência gerou enorme pressão da opinião pública doméstica das grandes potências, com especial destaque aos Estados Unidos.

Apesar do agravamento progressivo da crise, a postura dos Estados Unidos, até aquele momento, havia sido de cautela e não-envolvimento no conflito, por meio de alegações de defesa do princípio de não-intervenção. O então Presidente dos Estados Unidos, George Bush, já havia negado veementemente qualquer possibilidade de envolvimento americano no conflito somali.

O contexto interno americano também foi decisivo para essa postura, uma vez que o país estava mobilizado em torno de seu processo eleitoral para a escolha de um novo Presidente. Enquanto as eleições não foram definidas, nenhuma medida foi tomada pelo então governo Bush. A decisão de liderar o envio de tropas para a Somália só ocorreu após o resultado das urnas americanas ter dado a vitória a Bill Clinton. (MAYALL, 1996, p. 110)

A derrota nas urnas, aliada à fraca atuação dos EUA nos conflitos do Leste Europeu (Bósnia), transformaram a intervenção na Somália numa oportunidade para que o governo Bush mitigasse os erros com relação à política externa de sua gestão, e ainda, encerrasse seu 
mandato, mesmo que sem a reeleição, com um grande feito para o legado da administração Bush. (NATSIOS, 1996, apud WHEELER, 2000, p. 181)

O Secretário-Geral da ONU, Boutros-Ghali, também se posicionou mais fortemente em relação aos rumos da situação de emergência humanitária somali e da falta de interesse das grandes potências para agir. Boutros chegou a denunciar publicamente à inação da ONU. Em 29 de novembro, o secretário escreveu uma carta ao CS detalhando a deterioração da situação e o seu entendimento de que

"At present no government exist in Somalia that could request and allow
such use of force ${ }^{28}$. It would therefore be necessary for the Security Council
to make a determination under Article 39 of the Charter that a threat to the
peace exists, as a result of the repercussions of the Somali conflict on the
entire region, and to decide what measures should be taken to maintain
international peace and security. The Council would have to determine that
non-military measures as referred to in Chapter VII were not capable of
giving effect to the Council's decision". (BOUTROS-GHALI, 1992, p. 03)

Um dia após a divulgação da carta de Boutros-Ghali, o governo americano anunciou sua decisão de enviar 30.000 soldados para a Somália, com a tarefa de proteger e garantir o funcionamento da operação de ajuda humanitária. A partir daí, os EUA lideraram as negociações no interior do CS para a aprovação da Resolução 794, em três de dezembro de 1992, que em votação unânime aprovou a criação da Unified Task Force (Unitaf), também denominada de Operação Restore Hope.

Pela primeira vez, o Conselho de Segurança entendia que o sofrimento dos civis somalis constituía uma ameaça à paz e à segurança internacionais que justificasse uma resolução aprovada, unanimemente, sob o Cap. VII da Carta das Nações Unidas. Apesar do caso dos curdos no Iraque (Resolução 688) também ter sido considerado uma ameaça à segurança internacional pelas conseqüências externas que a repressão do Iraque aos curdos poderia gerar, os abusos de direitos humanos não foram identificados como legitimadores da ação sob o Capítulo VII, assim como nenhuma forma de ação coercitiva foi aprovada naquele caso. Por essa razão, a Resolução 794 tornou-se histórica.

Embora a justificativa do Secretário Geral, Boutros-Ghali, para a ação do CS tenha sido uma tentativa de encaixar o caso da Somália na regra pluralista que governa a ação de coerção do Capítulo VII da Carta da ONU, ficou evidente no debate realizado entre os membros do CS, que a principal razão para o recurso à força era a motivação humanitária.

\footnotetext{
${ }^{28}$ Boutros-Ghali está se referindo ao uso da força pelas Nações Unidas ou por algum de Estados membros, autorizado pelo CS da ONU. Conferir em: Carta do Secretário-Geral ao Presidente do Conselho de Segurança, 1992, p. 03.
} 
Tratava-se, portanto, da primeira vez que o Capítulo VII da Carta das Nações Unidas foi invocado por uma intervenção cuja motivação era de fato humanitária. (WHEELER, 2000, p. 183)

Características e resultados da Operação Restore Hope

“(...) the problem in Somalia and that efforts (to create conditions for the uninterrupted delivery of relief supplies to the starving people) are also required to create political conditions in which Somalia can begin to resolve its political problems and rehabilitate its economy. This is an integral part of UNOSOM's mandate and it is important that further measures to protect humanitarian relief supplies should be accompanied by continuing efforts to promote national reconciliation”. (BOUTROS, 1992, p. 01-02)

Apesar das recomendações de Boutros-Ghali ao CS e, principalmente, aos Estados Unidos, a disposição norte-americana para atuar na Somália estava restrita ao cumprimento exato do mandato que havia sido aprovado pelo CS, na Resolução 794, para aquela missão. A conduta americana na operação militar em solo somali pode ser definida pela ausência de qualquer comprometimento mais amplo com os aspectos políticos e de longo-prazo que a realidade somali exigia.

O distanciamento e a ausência de uma estratégia política que acompanhasse e sustentasse o sucesso das ações militares da Unitaf inviabilizou a assinatura de um acordo de paz duradouro entre as milícias. Esse posicionamento de não-engajamento no processo de reconstrução política da Somália promoveu ainda a substituição antecipada, em março de 1993, da Unitaf e da Unosom I pela Unosom II, representando a passagem da coordenação das ações dos EUA para a ONU.

Nessa ocasião, foi aprovada a Resolução 814, cujo mandato pretendia incorporar a idéia de reconstrução de Estados apresentada, por Boutros-Ghali, no documento An Agenda For Peace (Uma Agenda para a Paz) ${ }^{29}$ de 1992. Os esforços para incorporar a dimensão de reconstrução da Somália, refletido no mandato mais ambicioso já aprovado pela ONU, demonstravam a intenção de que o caso somali se tornasse um caso teste para essa concepção de intervenção aliada à reconstrução, assim como o otimismo precipitado da secretaria geral e dos membros da ONU. (WHEELER, 2000, p. 193)

O mandato sem precedentes na história da Organização, autorizou as forças da ONU, sob o Capítulo VII da Carta, a usar a força para implementar o seguinte mandato: criar um

${ }^{29}$ BOUTROS-GHALI, Boutros. An Agenda for Peace: preventive diplomacy, peacemaking and peacekeeping. Nova York: Nações Unidas, 1992. 
ambiente de segurança na Somália; promover a reconciliação política; estabelecer o Estado de Direito; promover a comprometimento de todas as partes somali, incluindo os movimentos e facções, com o comprometimento de que eles respeitariam os acordos de Adis Abeba, especialmente com relação ao cessar-fogo e desarmamento; e assistir a repatriação dos refugiados e reassentamento dos desabrigados.

Apesar da aprovação desse audacioso mandato, a ausência de uma estratégia militar amparada por uma estratégia política bem definida para a Somália, somada ao poder militar mais frágil da Unosom II, resultaram em episódios de violência contra os capacetes azuis no país, como a emboscada a 24 capacetes azuis paquistaneses, mortos numa inspeção da ONU no depósito da Somali National Alliance (SNA). O ataque aos soldados paquistaneses foi condenado e retaliado, por meio da Resolução 837, que autorizava a utilização de todos os meios necessários para que os responsáveis - cujos indícios demonstraram se tratar de uma emboscada preparada sob comando do General Aidid - fossem capturados e punidos.

Tal medida acabou por transformar a Unosom II numa caçada à Aidid - considerado culpado pelos ataques - resultando na morte de muitos civis somalis, principalmente crianças e mulheres, o que gerou um fortalecimento do apoio político à Aidid, assim como críticas da opinião pública internacional aos EUA. Em suma, a caçada à Aidid contrariava a racionalidade humanitária que havia levado à intervenção inicial dos EUA em dezembro de 1992. (WHEELER, 2000, p. 196)

A SNA, liderada por Aidid, respondeu aos ataques americanos, de julho de 1993, matando quatro soldados americanos num ataque à bomba e ferindo mais seis soldados com uma mina terrestre em agosto de 1993. A caçada à Aidid continuou até o início de outubro, quando foram contabilizados 18 soldados americanos mortos e 84 feridos. Após esse ataque, Clinton anunciou a retirada das tropas norte-americanas em 31 de março de 1994; logo depois a UNISON II foi abandonada e a ONU se retirou completamente da Somália até o fim de fevereiro de 1995.

A opinião púbica norte-americana que foi importante para o envio das tropas norteamericanas à Somália em 1992, foi igualmente importante para a retirada das tropas dos EUA pelo governo Bill Clinton, no início de 1994. O choque provocado pelas imagens das TVs, jornais e revistas dos somalis famintos, em meio ao conflito violento de facções, foi substituído pelo choque das imagens das mortes dos soldados americanos. 
Quando a retirada total do efetivo da ONU foi finalizada em março de 1994, a Somália apresentava poucas mudanças em relação ao cenário de urgência humanitária, caos político, ausência de lei e conflito armado entre os clãs e subclãs que haviam motivado a intervenção.

\section{Apontamentos Finais}

Não há dúvidas de que a flagrante situação dos civis somalis, em sua grande maioria crianças e mulheres, que morriam de fome, má nutrição e doenças, tenha correspondido ao primeiro requisito mínimo para que uma intervenção humanitária seja considerada legítima, isto é, ao critério de que uma emergência humanitária suprema esteja ocorrendo. A observância, portanto, desse primeiro critério conduz à análise do segundo critério básico de legitimidade de uma intervenção humanitária - o princípio de necessidade ou último recurso.

Pode-se afirmar que esse princípio não foi estritamente observado na intervenção somali, já que meios não-violentos de resolução de conflito, conduzidos pelo representante especial das Nações Unidas para a Somália, Mohammed Sahnoun, estavam produzindo resultados quando a ONU resolveu alterar sua estratégia de resolução do conflito abrindo espaço para o uso da força. (WHEELER, 2000, p. 203) O problema era que a preferência pela alternativa de usar a força acabou por ser colocado à prova quanto à capacidade de promover a resolução de um conflito, com as características da crise somali, no qual a fonte da violência estava profundamente enraizada nas estruturas sociais.

A atuação do representante especial da ONU em direção à descentralização do poder, por meio da promoção de novos líderes, em comunidades locais, por todas as regiões do país, visando o enfraquecimento dos líderes dos clãs e subclãs em conflito, concentrados na região central e na capital do país, não encontrou correspondência nas ações da ONU. A Organização não seguiu as recomendações de as operações de ajuda humanitária fossem descentralizadas, bem como não cumpriu com o envio dos 500 capacetes azuis que o CS havia aprovado, por meio da resolução $751^{30}$, já acordado e consentido pelas partes em conflito, graças à estratégia de negociação de Sahnoun.

\footnotetext{
${ }^{30}$ O envio dos capacetes azuis, aprovado em março de 1993, pela Resolução 751 só foi realizado pelas Nações Unidas em setembro de 1993, após o anúncio do envio de 3.000 soldados, sem o consentimento dos líderes do conflito, num claro aceno de mudança de estratégia da ONU. Isso demonstra a clara dissonância entre o comportamento da Organização e os esforços de negociação de seu representante especial, Sahnoun, que havia obtido arduamente o consentimento dos líderes das facções em conflito para que o efetivo de 500 soldados, aprovado em março, atuasse no país, num momento em que os líderes não admitiam, sob qualquer hipótese, o destacamento de tropas adicionais para a Somália. (WHEELER, 2000, p.178)
} 
A incapacidade da Organização de compreender que a complexidade do caso somali exigia essencialmente que os meios não-violentos de negociação fossem esgotados resultou no fortalecimento dos senhores da guerra de Mogadishu e, por conseqüência, no agravamento da situação na Somália que acabou por exigir que o recurso à força se tornasse o último recurso. No final, o princípio de necessidade, portanto, acabou sendo observado, não por ser a melhor estratégia, mas porque a inépcia da ONU produziu esse resultado.

O requisito de proporcionalidade foi parcialmente observado na intervenção humanitária na Somália. Se considerarmos o uso da força para a missão de distribuição de ajuda humanitária para alívio da fome, esse requisito foi atingido, em especial no período de implementação da Resolução 794. Mas, se considerarmos o momento em que a UNOSOM II deixou suas preocupações humanitárias fundamentais para perseguir o General Aidid como retaliação à morte dos soldados paquistaneses, seguida pelos ataques aos soldados americanos, especialmente no segundo semestre de 1993 e início de 1994, não é possível afirmar que esse critério básico tenha sido observado. O mais grave é que, além do não cumprimento do princípio de proporcionalidade a caçada à Aidid representou uma verdadeira descaracterização da intervenção humanitária, na qual os civis e a garantia de seus direitos humanos básicos foram relegados a segundo plano na atuação das tropas da ONU no país.

Considerando que no final de 1994, a situação da Somália em pouco se diferenciava do contexto, que no ano de 1992, possibilitou a aprovação da Resolução 794, que autorizava o uso da força a fim de garantir a distribuição de ajuda aos civis somalis, torna no mínimo controversa a afirmação de que a intervenção humanitária da ONU na Somália, sob liderança dos EUA, tenha sido bem sucedida, cumprindo assim o quarto e último requisito básico de uma intervenção humanitária legítima.

"The point that is usually made about Operation Restore Hope and UNOSOM II is that they failed. This is not wholly true with respect to the provision of humanitarian relief, but it is true if political rehabilitation and reconstruction are considered preconditions for preventing a recurrence and hence the underlying justification for the initial intervention”. (MAYALL, 2004, p. 132)

A afirmação de Mayall é cautelosa com relação à afirmação de insucesso da intervenção humanitária na Somália. Seu ponto de vista indica claramente a opção para que a análise dos resultados humanitários obtidos por essa intervenção seja realizada tanto a partir dos resultados humanitários de curto prazo, quanto dos resultados de logo prazo. Essa diferenciação permitiria afirmar que a intervenção humanitária na Somália produziu, sob a perspectiva de curto prazo, resultados humanitários positivos, bem como sob a perspectiva de 
longo prazo, resultados humanitários negativos, que demonstraram as limitações e os problemas da atuação da ONU e dos EUA nessa intervenção.

Diante da enorme quantidade de somalis que morriam todos os dias por má nutrição e inanição, especialmente na capital Mogadishu e na região central do país, onde não havia condições mínimas de segurança para a distribuição da ajuda humanitária aos civis, a perspectiva de curto prazo é entendida pela capacidade de cessar essas mortes. Como expressamente determinado na Resolução 794 de aprovação da Operação Restore Hope, o objetivo primordial das tropas armadas era criar condições mínimas de segurança que permitisse a entrega de ajuda humanitária aos milhares de somalis em situação de extrema emergência humanitária, impedindo que o número de mortes continuasse a crescer.

"Acting under chapter VII of the Charter of the United Nations, authorizes the Secretary-General and Member States cooperating to implement the offer referred in the paragraph 8 above $^{31}$ to use all necessary means to establish as soon as possible a secure environment for humanitarian relief operations in

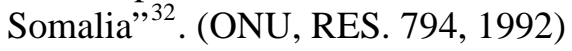

Por outro lado, a perspectiva de longo prazo é entendida pelo compromisso de que a intervenção compreenda, além das medidas de curto prazo, medidas mais amplas e complexas que possam alcançar resultados duradouros, como a reabilitação do Estado soberano que recebeu a intervenção. No caso somali, por exemplo, essas medidas compreenderiam o desarmamento das facções em guerra; o restabelecimento das instituições políticas e do Estado de Direito; a descentralização e a distribuição do poder que estava concentrado nas mãos das lideranças dos clãs; dentre inúmeras outras. O comprometimento com essas medidas poderia ter gerado resultados humanitários mais consistentes à população somali, evitando que num espaço de tempo tão curto após o término da intervenção uma situação humanitária catastrófica voltasse a ocorrer.

A questão do desarmamento das facções em conflito é um bom exemplo de como não houve por parte dos Estados Unidos, líderes da Operação Restore Hope, qualquer comprometimento com metas de longo prazo para o conflito somali. Apesar do desejo do Secretário Geral, Boutros-Ghali, de que as facções em guerra fossem desarmadas, os EUA recusaram-se a executar essa medida, sob alegação de que o sucesso da operação de entrega de ajuda humanitária dependeria do consentimento dos líderes das facções. A percepção de

\footnotetext{
${ }^{31}$ O Artigo 10 da Resolução 794 está referindo-se ao Artigo 8 do mesmo documento, no qual os Estados membros aceitam a oferta dos Estados Unidos de liderar a missão e enviar 3.500 soldados americanos para a missão. (S/RES 794 (1992) - Resolução do Conselho de Segurança da ONU, adotada em 03 de dezembro de 1992)

${ }^{32}$ Grifo Nosso.
} 
que a Somália seria uma operação livre de riscos e baixas, um dos motivos que fomentaram a decisão dos EUA de enviar suas tropas, baseava-se justamente numa estratégia de não envolvimento, que estivesse restrita pura e simplesmente ao mandato aprovado na Resolução 794 do CS, que neste caso representava uma operação com objetivos bem definidos e de curta duração.

O grande problema era que a complexidade do conflito somali exigia que a resolução eficaz da crise passasse pelo desarmamento dos líderes das facções e pelo estabelecimento de um Estado de Direito. Medidas circunscritas e apolíticas não evitariam que a guerra civil e as mortes por inanição reincidissem na Somália. Contudo, ajudar os somalis a criar instituições políticas e institucionais exigia um comprometimento de soldados e recursos de longo prazo, missão que os EUA definitivamente não estavam dispostos a assumir ${ }^{33}$.

Após essa análise dos critérios básicos que podem conferir legitimidade às intervenções humanitárias, é importante destacar outros critérios, como a aprovação do CS da ONU, que foram decisivos para que a intervenção humanitária na Somália fosse considerada amplamente legítima. No que se refere à aprovação da ONU, a intervenção humanitária na Somália, aprovada pela Resolução $794^{34}$, representou uma evolução no pensamento do Conselho de Segurança sobre a legitimidade das intervenções humanitárias, já que os Estados membros entenderam unanimemente que a situação humanitária na Somália poderia justificar uma ação militar, sob o Capítulo VII da Carta da ONU, ou seja, sob a justificativa de que a situação somali constituía uma ameaça à paz e à segurança internacionais. (WHEELER, 2000, p. 200)

A aprovação unânime dessa resolução demonstrou, pela primeira vez em toda a história do CS, que seria possível, dentro dos arranjos legais e institucionais existentes, justificar uma intervenção militar com propósitos humanitários. Perante a ausência de uma base legal que pudesse autorizar uma intervenção justificada por argumentos humanitários, como as graves violações dos direitos humanos dos somalis, a alternativa que restou aos

\footnotetext{
${ }^{33}$ Mesmo diante das evidências de que a única forma de ajudar a Somália a desmilitarizar sua sociedade dependia da transferência do poder dos líderes das facções em conflito para os líderes comprometidos com políticas de não-violência, a escolha dos EUA foi de negociar com os líderes das faç̧ões propondo que eles mantivessem suas armas, sob a condição de que eles se retirassem de Mogadishu ou da área sob monitoramento da ONU. O que corrobora ainda mais a percepção de ausência de qualquer comprometimento dos americanos com uma missão de longo prazo na Somália. (WHEELER, 2000, p. 190-1)

${ }^{34}$ Importante ressaltar que o paralelo mais próximo da Resolução 794 é a Resolução 770 adotada, em agosto de 1992, quando o CS autorizou o uso da força para garantir a entrega de ajuda humanitária na então Yugoslávia. Contudo, essa Resolução tem significado menor, em termos de mudança nos princípios pluralistas que estruturam a sociedade de Estados, porque sua aprovação foi mediante o consentimento do Estado soberano, no caso a Bósnia-Herzegovina. (WHEELER, 2000, p. 200)
} 
membros do Conselho foi recorrer ao Artigo VII da Carta da ONU. “Given the almost certain impossibility of revising the Charter to include a formal right of humanitarian intervention under chapter VII, there are obvious practical advantages in its ability to interpret its responsibilities flexibly”. (MAYALL, 2004, p. 133)

Os discursos e argumentos empregados no processo de aprovação da Resolução 794 evidenciaram, por sua vez, a habilidade de interpretar flexivelmente as responsabilidades e a prerrogativa do uso da força do próprio Conselho, não surgiu de uma verdadeira preocupação com relação à ameaça que o conflito somali poderia representar à segurança internacional, mas sim da preocupação com a situação humanitária naquele país. (WHEELER, 2000, p. 1834) O preâmbulo da Resolução 794, aprovada unanimemente pelo Conselho de Segurança justificou o emprego do Capítulo VII e a intervenção militar em um território soberano estimando que "the magnitude of the human tragedy caused by the conflict in Somalia, further exacerbated by obstacles being created to the distribution of humanitarian assistance, constitutes a threat to international peace and segurity”. ${ }^{35}$

A questão é identificar em que medida, de fato, a crise humanitária na Somália constituía uma ameaça à segurança regional e quiçá à internacional. Embora esse tenha sido o argumento para a aprovação da Resolução 794, não havia quaisquer indícios que confirmassem essa correlação, uma vez que os principais efeitos do conflito somali foram no âmbito doméstico. O fluxo de refugiados para os países vizinhos (Quênia, Etiópia e Djibuti), por exemplo, concentrou-se no início do conflito, mas não chegaram a constituir uma preocupação que justificasse uma ameaça à segurança regional.

Não houve qualquer menção, dos países vizinhos à Somália, por exemplo, de que a ameaça à segurança regional, devido ao fluxo de refugiados, justificaria recorrer ao uso da força no interior de um Estado soberano, segundo o princípio de legítima defesa; argumento tão freqüentemente utilizado nas intervenções unilaterais que buscaram a aprovação da ONU no período de Guerra Fria ${ }^{36}$. Embora não se tratasse de uma intervenção unilateral e a liderança da missão não estivesse sob a responsabilidade de um país vizinho à Somália, é importante destacar a alteração dos argumentos dos Estados a fim de obter a aprovação e a legitimidade das Nações Unidas para as intervenções humanitárias.

\footnotetext{
${ }^{35}$ Resolução 794 de 03 de dezembro de 1992. Preâmbulo, Alínea 3.

${ }^{36}$ Conferir no Capítulo II os três casos de intervenção unilareral durante os anos 1970: Índia (1971), Vietnã (1979) e Uganda (1979).
} 
A ausência de contestação sobre a legitimidade da ação do CS com relação à Resolução 794, de acordo com a perspectiva de Wheeler, refletiu um novo entendimento intersubjetivo entre os Estados membros da Organização, o qual estabeleceu que,

“(...) when governments had collapsed into lawlessness and starvation, the UN had a moral responsibility to intervene to provide security for the citizens of that state. This changed the understanding of the Security Council's responsabilities under Article 39 of Chapter VII, marking a major departure from the pluralist interpretative framework that had hitherto governed the application of this rule”. (WHEELER, 2000, p. 200)

O papel da autorização da ONU foi preponderante para que os EUA realizassem a intervenção militar, já que sem essa autorização o governo Bush não teria agido. Desse modo, a legitimação da ONU foi vital para assegurar que a missão seguisse os objetivos pretendidos pelo governo americano, principalmente com relação à transmissão do mandato da operação dos Estados Unidos para as forças da Organização logo que um novo Presidente fosse eleito no país. Além disso, a aprovação da ONU foi essencial para que o governo americano conseguisse manter a legitimidade doméstica necessária para a ação. (WHEELER, 2000, p. 182)

Além da aprovação da ONU, o governo americano obteve legitimidade doméstica para empregar suas forças militares também devido ao resultado do chamado efeito $C N N$, no qual o papel da mídia americana, sem dúvida, contribuiu para a decisão do governo Bush de enviar tropas militares para liderar a Operação Restore Hope da ONU.

"The case of Somalia, like those of others, shows that the relationship between the selective attention devoted to foreign events by public authorities and the media is more nuanced and mutually reinforcing: the media will cover stories where US personnel are involved more than other stories. But the prospect of US involvement increases if the US media covers a foreign crisis in a big way”. (THAKUR, 2006, p. 55)

Na avaliação de Wheeler, o poder da mídia para comover a consciência da opinião pública americana foi um fator importante para a ação dos EUA, mas a existência dessa razão pública de legitimidade, junto com o suporte da Resolução 794, não determinou a intervenção norte-americana. A razão pública de legitimidade da ação dos EUA foi uma condição necessária, mas não suficiente. (WHEELER, 2000, p. 201) Segunda essa perspectiva, os motivos que permitiram a ação do governo norte-americano foram os impulsos humanitários do Presidente norte-americano, George Bush, e de seus conselheiros políticos; o desejo da administração Bush de terminar a presidência com algum fato digno de nota e desviar a 
atenção de sua inação no caso da Bósnia ${ }^{37}$ a autorização da ONU; e, o mais importante, a percepção de que a Somália era uma operação livre de risco e de curta duração. (WHEELER, 2000, p. 180-181)

A percepção de que a operação seria curta e livre de risco era proveniente do fato de que a missão seria restrita à proteção da entrega de ajuda humanitária e confinada as regiões geográficas mais devastadas. Além disso, as tropas americanas deveriam entregar a missão às forças de manutenção de paz (peacekeeping) das Nações Unidas assim que um novo Presidente fosse eleito. Essa última condição foi crucial para a aprovação da operação e fundamentava a convicção de que a missão traria pouco ou nenhum risco para a vida dos soldados americanos.

Ainda sob essa avaliação, as justificativas humanitárias da administração Bush para intervir reúnem um grupo complexo de motivações humanitárias e não-humanitárias. No entanto, o fator chave desse grupo de motivações mistas é que não há qualquer evidência de que os EUA tenham escondido razões de poder político para intervir, que entrassem em contradição com os propósitos humanitários declarados na Operação Restore Hope. (WHEELER, 2000, p. 180-181) De certa forma, há que se considerar que os motivos do governo Bush para liderar a intervenção com uso da força na Somália, excluindo os motivos ligados à aprovação da ONU e a pressão da opinião pública doméstica americana, não estavam ligados a nenhum interesse político ou estratégico que suplantasse as preocupações humanitárias.

A aprovação unânime da Resolução 794 pelo CS parecia, portanto, ter iniciado um processo de mudança significativa no contexto normativo que legitima as intervenções. O uso pioneiro e a legitimidade dos argumentos humanitários pelos membros do Conselho como justificativa para o uso da força, bem como o acordo sobre a competência legal do CS em lidar com aquela crise humanitária, mesmo no interior das fronteiras de um Estado soberano, forneciam o substrato para essa percepção de mudança normativa. Além disso, igualmente pioneira teria sido a posição de que o CS tinha a responsabilidade moral de salvar as vítimas da emergência humanitária somali expressa por vários membros do Conselho. (WHEELER, 2000, p. 185),

\footnotetext{
${ }^{37}$ A diferença entre a resposta americana ao caso da Bósnia e ao caso da Somália suscita a principal objeção realista à legitimidade de uma intervenção humanitária particular: a seletividade. Em resposta à essa objeção, o então secretário de Estado do governo Bush durante a crise somali, Lawrence Eagleburger, argumenta que o impulso moral para salvar vidas deve ser balanceado contra os custos e riscos envolvidos. (WHEELER, 2000, p. 181)
} 
Não obstante, apesar da percepção de que o caso da intervenção humanitária na Somália indicava uma mudança significativa no contexto normativo de legitimidade das intervenções, o pioneirismo do caso somali foi contestado pelo argumento de que esse seria um caso de intervenção humanitária excepcional porque não seria um caso de intervenção contra a vontade de um governo, mas sim uma intervenção na ausência de governo. (ROBERTS, 1993, p. 440)

Na prática, o argumento da excepcionalidade do caso somali e, conseqüentemente, de que não houve violação ao princípio de não-intervenção porque o governo da Somália estava em colapso pode ter até persuadido a China e a Índia a não considerarem a aprovação da Resolução 794 uma ameaça a esse princípio. Para esses dois países, a intervenção na Somália tratava-se de um caso único, excepcional e que, portanto, não representava a abertura de qualquer precedente que minasse a ordem internacional vigente, baseada no princípio de nãointervenção. Porém, o argumento da excepcionalidade precisa ser analisado mais detidamente a partir do caráter legal que define o reconhecimento da existência de um Estado.

O problema com esse argumento concentra-se no fato de que os Estados, e não os governos, é que são reconhecidos pelo Direito internacional como os portadores de direitos e obrigações. Embora o Estado somali e o governo somali tenham sido tomados como sinônimo nas discussões do CS para a aprovação da Resolução 794, Estado e governo não são sinônimos. No direito costumeiro, relacionado ao reconhecimento do Estado, o governo é um critério para a existência do Estado, mas a existência de um Estado não se reduz a seu governo. Conseqüentemente, o colapso do governo somali não significou que o Estado somali deixou de existir em senso jurídico. (WHEELER, 2000, p. 187)

Por outro lado, o reconhecimento legal da existência de um Estado é definido a partir do reconhecimento desse Estado pela sociedade de Estados existente. Sendo assim, a opção da China e da Índia foi de negar o reconhecimento da existência do Estado somali, para assim garantir que a aprovação da Resolução 794 tivesse um caráter de extraordinariedade. Dessa maneira, sem o reconhecimento da existência de um Estado soberano como objeto daquela intervenção, não haveria a sensação de que um precedente para a violação dos princípios de soberania e não-intervenção estivesse sendo inaugurado. (WHEELER, 2000, p. 187)

Apesar do argumento de excepcionalidade da intervenção humanitária na Somália, de modo geral, a percepção da sociedade internacional, desenvolvida a partir do caso somali, parecia indicar que um novo entendimento normativo e intersubjetivo com relação à legitimidade das intervenções, baseada em motivos humanitários, estava nascendo entre os 
Estados, principalmente os ocidentais, e que uma vez libertos dos constrangimentos da Guerra Fria, estes passariam a usar seus exércitos para salvar estrangeiros em lugares distantes. Tal expectativa não resistiu a Ruanda.

\subsubsection{A mais vergonhosa paralisia: a sociedade internacional como observadora do genocídio em Ruanda em 1994}

A intervenção humanitária na Somália, em 1992, havia gerado um otimismo com relação à promoção da justiça dentro dos arranjos institucionais existentes na sociedade internacional, em especial pela utilização das atribuições do CS com relação ao Capítulo VII da Carta da ONU a partir de motivos humanitários. A pretensa disposição da sociedade internacional de proteger os direitos básicos dos indivíduos, independentemente de sua nacionalidade, sem fazer com que isso representasse uma ameaça aos princípios constituintes da ordem internacional não se mostrou real diante da opção da sociedade internacional de assistir ao genocídio de Ruanda como expectadora global.

Os Antecedentes da Intervenção

"The recent history of Rwanda is a textbook case of how racism and ethnic hatred can be planted in a society”.

John Shattuck, 2003.

Quando os colonizadores alemães, seguidos pelos colonizadores belgas, chegaram à Ruanda no fim do século XIX, encontraram um reino relativamente estável que por dois séculos permaneceu isolado do tráfico de escravos costeiro devido ao seu terreno montanhoso. Os hutus e tutsis ocupavam o território montanhoso correspondente a atual Ruanda convivendo, de modo geral, num clima de relativa paz, com poucos levantes de violência entre os grupos.

A diferenciação entre eles baseava-se muito mais em critérios sócio-econômicos do que propriamente por diferenciação étnica. De forma geral, os tutsis compunham a elite sócioeconômica tradicional, cuja principal atividade produtiva era a pecuária, enquanto os hutus cultivavam os campos. Entretanto, hutus e tutsis falavam a mesma língua (Kinyarwandan), casavam entre si, e dividiam a mesma religião e estrutura social. As distinções étnicas e 
raciais entre os grupos surgiram somente após a chegada dos colonizadores, que traziam em sua bagagem a influência de uma era em que a ciência reconhecia a existência de raças e da superioridade de uma determinada raça sobre as outras.

"The colonial powers ruled in a manner that reinforced their own biases while undermining the structure of Rwandan society. The Germans and later the Belgians used racial stereotyping to select the Tutsi for the colony's administrative elite, thereby creating artificial racial distinctions that exacerbated earlier social tensions”. (GOLDSTONE apud SHATTUCK, 2003, p. 28)

O sistema racial foi formalizado pelos belgas em 1933 quando eles realizaram um censo que guiaria a distribuição de cédulas de identidade baseadas nas características físicas, o que evitaria que hutus, designados como inferiores, se tornassem tutsis. As diferenças politizadas e fundamentadas em termos raciais entre hutus e tutsis, com explícito privilégio dos tutsis, estabelecidas pelos colonizadores belgas causaram todas as lutas subseqüentes pelos escassos recursos de terra e animais do território ruandês.

O clima de divisão racial e étnica transformou-se em divisão política com a independência de Ruanda. Ressentidos pelo poder político exercido pela monarquia tutsi sob a lei colonial belga, os hutus se rebelaram em 1959. "The popular uprising of Hutus against Tutsi authorities that began in 1959 and became known in Rwanda as "the wind of destruction" was the first recorded instance of systematic political violence between Hutus and Tutsis in Rwanda's history (...)”. (SHATTUCK, 2003, p. 29)

O violento conflito resultou na queda da monarquia tutsi, após a retirada das forças belgas em 1961. Os hutus chegaram ao poder, referendados pela ONU em 1961 e o país permaneceu sob a tutela da Organização até se tornar independente em 1962. Nesse mesmo ano, um dos líderes da revolução hutu, Gregorie Kayibanda, tornou-se o primeiro Presidente pós-independência. Em 1973, um golpe derrubou o governo de Kayibanda e o chefe do Exército ruandês, Juvenal Habyarimana, ocupou a presidência.

Durante seu governo, Habyarimana declarou o fim dos assassinatos dos tutsis, mas ao mesmo tempo, fortaleceu o sistema de identidade racial, impediu o acesso dos tutsis às posições políticas e administrativas. Essa política de exclusão dos tutsis gerou um problema em relação aos quase um milhão de tutsis que deixaram seu país. Os tutsis se estabeleceram em Uganda e lá formaram o Rwandan Patriotic Front (RPF), que nos anos 1990 iniciaram 
suas incursões militares no noroeste de Ruanda. O RPF lutava pelo reconhecimento dos direitos políticos e sociais dos refugiados tutsis e por um acordo de poder compartilhado.

Nesse contexto, o governo ruandês vinha recebendo crescente pressão internacional, principalmente dos EUA e da Europa, para que um processo de paz fosse negociado com o RPF. Os doadores internacionais indicaram que a assistência econômica ao país estaria condicionada à mudança constitucional e melhora no respeito aos direitos humanos. Em 1991, o Presidente cedeu à criação de uma constituição multipartidária, que permitiu a formação de outros três partidos que agora dividiram o exercício político e seriam opositores do partido do governo, o Movimento Nacional para a Revolução e o Desenvolvimento (MNRD).

Dois anos depois, Habyarimana relutantemente assinou um acordo de paz, em agosto de 1993, em Arusha, na Tanzânia, no qual concordava em dividir o poder com o RPF; permitir o retorno dos refugiados tutsis e sua integração às forças armadas ruandesas; e estabelecer um governo de transição para que novas eleições fossem realizadas. Em outubro do mesmo ano, a U.N. Assitence Mission to Rwanda (UNAMIR), aprovada pelo CS da ONU, através da Resolução 872, chegou ao país com a tarefa de auxiliar pacificamente o processo de implementação dos acordos de Arusha.

Foi justamente a oposição dos elementos extremistas do MNRD à divisão do poder com os hutus moderados e os tutsis que levou à concepção de um plano secreto que envolvia o treinamento de milícias armadas (a interahamwe e a impuzamugambi) para assassinar tutsis e hutus moderados e a manipulação via transmissão de rádio do ódio da população hutu contra os tutsis. (SHATTUCK, 2003, p. 31)

O plano de genocídio dos tutsis entrou em funcionamento no dia 06 de abril de 1994, poucas horas após o avião que trazia o Presidente Habyarimana de Arusha ter sido alvejado em circunstâncias ainda desconhecidas. A crença da maioria hutu na propaganda extremista de que sua sobrevivência dependia da eliminação física dos tutsis - proveniente da politização das diferenças raciais e étnicas entre tutsis e hutus pela colonização belga - exterminou oitocentas mil pessoas em apenas quatorze semanas. "The fact is that this genocide, like that of the Holocaust, was the product of deliberate political design”. (WHEELER, 2000, p. 209) Esse desenho político deliberado que rivalizou tutsis e hutus, na lógica do dividir para dominar, havia encontrado a oportunidade para mostrar impiedosamente sua face mais perversa. 
Um genocídio inevitável: isso é mesmo possível?

A história colonial de Ruanda, a revolução política hutu contra a elite colonial tutsi e a subseqüente resistência armada contra a expulsão dos tutsis de Ruanda foram indícios de que um processo de violência poderia estar em curso. Além de indícios, não faltaram avisos para que a sociedade internacional tomasse conhecimento do plano de extermínio dos tutsis. Após a assinatura do Acordo de Arusha, representantes do governo ruandês e do RPF já haviam alertado as Nações Unidas sobre a fragilidade do acordo.

Em janeiro de 1994, o comandante da UNAMIR, General Romeo Dallaire do Canadá, também já havia alertado à ONU por meio de um telegrama a respeito do cataclisma iminente. No telegrama, Dallaire pedia proteção para um informante que pertencia à milícia armada Interahamwe dos hutus extremistas. Todo o plano de genocídio dos tutsis foi revelado por esse informante, que afirmou não existir força política no interior de Ruanda capaz de conter o que estaria por vir. A mensagem ainda afirmava que o Presidente Habyarimana não tinha total controle sobre os elementos de seu partido ou facção. A proposta do General Dallarie é que as tropas da ONU recebessem autorização para atacar os esconderijos de armas da Interahamwe.

Nada foi feito em resposta à advertência, ou mesmo, à proposta de Dallaire. As informações contidas no telegrama não receberam qualquer atenção do secretariado das Nações Unidas, que estava sob o comando de Boutros-Ghali, e nem sequer chegaram ao Conselho de Segurança.

\footnotetext{
"Paralyzed by the failure of the Somalia mission three months earlier, limited by the tight leash imposed by the United States on post-Somalia peacekeeping activities, and overwhelmed by the seventeen other peacekeeping missions it was then managing, the United Nation's grossly understaffed peacekeeping office, then headed by Kofi Annan, did not give Dallaire the tools he was asking for". (SHATTUCK, 2003, p. 35)
}

A atuação da ONU na Somália, sem dúvida, era um dos principais focos de preocupação da Organização e um fator determinante para a escolha do posicionamento da Organização em relação ao agravamento da escalada de violência em Ruanda. Dois dias antes do Conselho de Segurança discutir e aprovar o envio da UNAMIR para Ruanda, dezoito soldados americano foram mortos em Mogadishu. As duas principais operações da ONU, a Somália e a Bósnia, influenciaram determinantemente os rumos e o mandato da UNAMIR, cujas atribuições limitaram-se ao monitoramento do cessar-fogo acordado em Arusha. O 
posicionamento da ONU em relação à UNAMIR havia dado um claro sinal aos extremistas hutus de que eles poderiam agir impunemente, sem encontrar obstáculos por parte da Organização. (WHEELER, 2000, p. 215)

Um dia antes do início do massacre, o CS reuniu-se para discutir a renovação do mandato da UNAMIR por mais seis meses e sob forte pressão dos EUA, o Conselho acabou por aprovar a Resolução 909. A determinação dessa resolução era de que a ONU se retirasse do país em seis meses, a menos que um governo de transição fosse criado. Nas deliberações do Conselho, não se cogitou que a UNAMIR poderia exercer um importante papel na proteção dos civis ruandeses, principalmente dos tutsis e hutus moderados, alvos diretos da política de extermínio dos extremistas hutus. (WHEELER, 2000, p. 217)

Diante da deterioração das condições de segurança para a permanência dos capacetes azuis no país, já que eles também foram alvo de ataques quando tentaram impedir que as milícias hutus executassem seu plano de extermínio de tutsis e hutus moderados, a escolha das Nações Unidas foi por sua retirada do país.

“(...) the United Nations could have beefed up its peacekeeping operation and given it the authority and the means to defend itself. Paradoxically, the most effective way at this point for the U.N. to have avoided being sucked into an endless conflict it could not contain would have been for it to respond forcefully and immediately to the threat against it peacekeepers both in order to save their lives and to demonstrate to the genocide planners that they would be confronted with force if they continued to pursue their criminal design”. (SHATTUCK, 2003, p. 37)

Uma aposta da ONU no fortalecimento de suas forças ao invés de sua retirada, baseda na mudança no caráter da UNAMIR, que passaria a ser uma missão de imposição da paz ao invés de uma missão para a manutenção da paz, teria sinalizado às milícias extremistas de que a sociedade internacional não permitiria o massacre planejado. Em 17 de abril, o General Dallaire fez um apelo para que a Organização enviasse cinco mil soldados sob um forte mandato, para que as estradas de acesso à capital, Kigali, fossem bloqueadas pelos soldados da ONU, impedindo que as milícias alcançassem o interior do país levando seu rastro de destruição e barbárie. Apesar disso, a possibilidade de alterar o mandato da UNAMIR de peacekeeping para uma intervenção humanitária preventiva sequer foi discutida pelo CSNU. (WHEELER, 2000, p. 217-8)

\section{A linha Mogadishu}


A opção da sociedade internacional de permanecer como observadora passiva diante do genocídio de milhares de civis ruandeses, representada pela flagrante inação de sua organização internacional máxima, pode ser explicada por duas razões principais: a questão legal de como justificar a infração da soberania de Ruanda, sob o argumento de necessidade de uma intervenção humanitária preventiva que evitasse o genocídio que se anunciava; e a ausência de um Estado com capacidade e disposição para liderar a intervenção em Ruanda, arcando com seus custos financeiros e humanos. No primeiro caso, se Ruanda tivesse sido identificada como genocídio, o CS poderia ter determinado sobre o Artigo 39 da Carta que o risco de genocídio constituía uma “ameaça a paz” que justificaria o uso das provisões coercitivas do Capítulo VII da Carta da ONU. O problema é que não é possível saber qual teria sido a recepção e a aquiescência dos membros do CS a esse argumento, já que não havia precedente legal para tal uso, ou mesmo a reivindicação de algum Estado membro nesse sentido. (WHEELER, 2000, p. 218)

A segunda razão, por sua vez, baseia-se na ausência de candidatos dispostos a ultrapassar a linha Mogadishu. Ultrapassar tal linha, cujo nome é uma referência à capital da Somália, significava a disposição de arcar com uma ação coercitiva em Ruanda, num paralelo com a situação enfrentada pelos EUA na Somália.

"For a long time, the Somalia debacle would cast a shadow over U.N peacekeeping operations, and for nearly a year it was to paralyze the Clinton administration as it confronted other human rights crises in Rwanda and Bosnia, keeping it from participating it - or even supporting - similar interventions”. (SHATTUCK, 2003, p. 22)

Os Estados Unidos estavam paralisados por sua política pós-Somália que postulava que a atuação do país deveria trabalhar ativamente contra o estabelecimento ou continuação de qualquer missão de manutenção de paz da ONU quando estivessem ocorrendo hostilidades em campo. Essa nova diretriz teve relevante influência na atuação dos Estados Unidos, que influenciaram para que a alternativa de intervenção humanitária não fosse sequer discutida no CS, bem como pressionaram fortemente o Conselho para que as tropas da UNAMIR fossem retiradas de Ruanda, o que de fato aconteceu após a aprovação de uma Resolução 912, em 21 de abril, que determinava a retirada de noventa por cento das tropas da ONU do país, restando apenas 270 soldados que eram ruandeses. (SHATTUCK, 2003, p. 41)

O relatório preparado pelo Secretário-Geral da ONU, Boutros-Ghali, a respeito da situação em Ruanda exerceu forte influência na decisão de aprovação da Resolução 912, que determinava a retirada total dos soldados estrangeiros do país. Diferentemente do que o 
General Dallarie havia reportado em seu telegrama em 08 de abril, Boutros-Ghali nomeou a violência como uma guerra civil, baseada em motivos étnicos, e não como um genocídio, comprovando a determinação de que não haveria intervenção da ONU para cessar os massacres. O relato do então comandante da UNAMIR vinha em direção oposta a interpretação de Boutros-Ghali, uma vez que o General Dallaire não havia afirmado que a matança em Ruanda era baseada em origem étnica.

Além disso, o Secretário-Geral não mencionou em seu relatório a preocupação de Dallaire com a proteção dos direitos humanos dos civis ruandeses, que se refugiavam nos campos da UNAMIR, transformando-os em verdadeiras zonas seguras para as vítimas do genocídio em busca de proteção. Desse modo, o relatório do Secretário-Geral teve um profundo impacto no pensamento dos membros não-permanentes, que não ousaram desafiar a interpretação das causas do massacre, o que resultou na aprovação unânime pelo CS da Resolução 912 que reduzia a UNAMIR. (WHEELER, 2000, p. 220-1)

A sombra da Somália também esteve presente nos esforços da administração Clinton em impedir que governos, ONGs, a mídia, e a própria ONU nomeasse o que estava acontecendo em Ruanda como genocídio, uma vez que essa denominação representava mais do que uma simples nomenclatura, representava também implicações políticas, pois a Convenção contra o Genocídio (1948), ratificada pelos EUA em 1988, geraria uma pressão para que o genocídio, reconhecido como crime no Direito Internacional, fosse evitado ou combatido. "If the power of naming Rwanda a 'genocide' frightened the Clinton Administration, the it was exactly the normative power of Convention to enable intervention that some members of the Council and several NGOs were trying to enlist to save the victims of the genocide”. (WHEELER, 2000, p. 225)

Da observação passiva à intervenção: a Operação Turquoise

No fim do mês de abril de 1994, o extermínio dos tutsis e hutus moderados em Ruanda finalmente ganhou a atenção da mídia internacional. Embora a opinião pública doméstica das grandes potências não tenha pressionado seus governos, como aconteceu com o governo americano no caso somali, o horror gerado a partir das imagens do genocídio em Ruanda, distribuídas mundialmente, adensou as críticas dos países africanos e de alguns países europeus, como a Nova Zelândia e a República Tcheca, com relação à inação da ONU perante aquela verdadeira carnificina. 
Como resultado dessas críticas, o então Secretário-Geral da ONU, Boutros-Ghali, manifestou-se no início de maio de 1994 descrevendo pela primeira vez a situação em Ruanda como genocídio. Sua resposta às crescentes críticas foi recomendar ao CS que a UNAMIR recebesse um reforço de 5.500 soldados, com mandato de provisão de assistência humanitária. O CS acatou a recomendação e aprovou em oito de junho unanimemente a Resolução 925, que autorizava o emprego do reforço das tropas da Organização em Ruanda.

Como a situação continuava deletéria naquele período, o governo francês se ofereceu para liderar uma missão de resgate multinacional, que serviria como uma medida temporária, até que a UNAMIR II fosse inteiramente empregada. A França justificou a intervenção em Ruanda pela preocupação em salvar as vidas dos grupos visados pelo plano genocida. Entretanto, para assegurar a legitimidade doméstica e internacional da missão, o então Primeiro-Ministro, Édouard Balladur, identificou cinco pré-condições: a operação deveria ter autorização do CS; toda a operação deveria se limitar a ações humanitárias; as tropas deveriam permanecer na fronteira com o Zaire; as tropas não deveriam entrar no coração de Ruanda ou se envolver no conflito com o RPF; e, finalmente, a missão deveria ser limitada ao máximo de dois meses antes da entrega de comando para a UNAMIR II.

Ao justificar a ação nesses termos e estabelecer dentre as pré-condições para agir a autorização do CS, a França esperava conferir legitimidade à sua iniciativa de liderar a intervenção, dissipando as críticas de que o país estava envolvido demais com o governo de Habyarimana para atuar como liderança no salvamento dos tutsis e hutus moderados em Ruanda. Contudo, a aprovação da ONU não evitou que a própria imprensa francesa circulasse acusações de que o real propósito da missão "humanitária” do governo francês tinha como objetivo salvar um governo parceiro que estava perdendo a guerra para o RPF. (WHEELER, 2000, p. 231)

As credenciais francesas para a missão foram colocadas em xeque já de início pela postura da França de não-envolvimento com relação ao genocídio em Ruanda. Em consonância com todo o CS, que logo após o início do extermínio votou pela neutralização da UNAMIR, a França também optou por permanecer como observadora passiva dos massacres. Assim, quando o país se candidatou para liderar a missão, apesar das dúvidas sobre as credenciais do país, nenhum membro do Conselho se sentiu publicamente capaz de criticar a ação francesa que era justificada em termos humanitários.

Apesar da demora da mobilização do interesse francês em agir em Ruanda, o que de fato provocava sérias dúvidas a respeito das intenções da França em liderar essa intervenção 
humanitária era o relacionamento de parceria entre o governo francês e o antigo governo ruandês do Presidente Habyarimana. A França havia fornecido armas e consultoria militar ao Presidente hutu ruandês, desde o golpe que o levou ao poder. A suspeita, então, era de que a França teria interesse em combater as forças tutsis do RPF a fim de devolver o poder a seus antigos clientes, que oficialmente ainda representavam o governo ruandês.

O emprego de seu poderio militar, assim como a restituição do poder de seu antigo cliente, demonstraria a capacidade francesa de continuar projetando poder no continente, contendo o avanço dos anglófonos na parte da África considerada pela França como sua área de influência. Isso porque o RPF, apoiado por Uganda, de colonização inglesa, vinha conseguindo progressivas vitórias contra as milícias extremistas hutus. Sendo assim, diante da perda do cliente ruandês, tornou-se urgente na percepção francesa demonstrar para todo o continente africano e para o resto do mundo que a França tinha poder de fato e poderia projetá-lo rapidamente no continente quando fosse necessário. (WHEELER, 2000, p. 233)

Essas motivações ocultas tornaram-se crescentemente aparentes quando a França declarou a existência de uma zona humanitária segura na parte sul de Ruanda ocidental. Só o fato de ter criado essa zona segura tornava a atuação francesa imparcial, contrariando as atribuições do mandato da Operação Turquoise. O mais grave, porém, é que membros do RPF eram proibidos de entrar nesse território, que havia se convertido num santuário para a recomposição das forças militares ruandesas e das milícias responsáveis por aquele extermínio. Além disso, existem evidências consideráveis de que os militares franceses estavam secretamente fornecendo armas ao Exército ruandês e as milícias durante o genocídio.

Em campo, o vergonhoso apoio da França aos perpetradores do genocídio era evidente na recusa dos comandantes franceses em prender os suspeitos de crime de guerra, pertencentes ao grupo dos hutus extremistas; em prevenir os saques das cidades que estavam dentro da zona segura, estabelecida pela própria missão francesa; e em fechar a estação de rádio que continuava a transmitir a propaganda de ódio, encorajando os hutus a eliminar qualquer tutsi que estivesse vivendo na zona humanitária segura. (WHEELER, 2000, p. 234)

O resultado da Operação Turquoise, liderada pela França, resumia-se em mais de meio milhão de refugiados deixando a zona humanitária pelo Zaire; a uma estimativa de trinta mil mortos por cólera nos campos ruandeses durante o mês de julho; e talvez treze mil resgatados contra mais de um milhão de mortos durantes os três meses anteriores, ou seja, resumia-se em 
uma resposta deplorável por parte da sociedade de Estados ao genocídio em Ruanda. (WHEELER, 2000, p. 237)

\section{Apontamentos Finais}

O caso de Ruanda parece ser o contraposto da expectativa normativa que a intervenção humanitária na Somália havia gerado. A mobilização da sociedade internacional, liderada pelos Estados Unidos; da opinião pública doméstica das grandes potências; e da própria ONU diante das mortes por inanição do caso somali pareciam indicar que as expectativas de promoção da justiça no sistema internacional haviam encontrado uma forma conciliatória com a defesa da ordem existente.

Ruanda foi, portanto, a frustração dessa expectativa, porque demonstrou as limitações da ONU em implantar as diretrizes normativas que privilegiariam a justiça, dentro do arcabouço da ordem internacional existente, sem o apoio e a disposição das grandes potências. Embora a Somália tenha representado para a Organização os novos passos de uma nova agenda com princípios mais solidaristas, a intervenção somali tinha criado para a grande potência mundial um fantasma, que foi determinante para a paralisia de toda a sociedade internacional frente ao genocídio em Ruanda.

"The transitional from the end of the Bush senior administration to the end of Clinton's second term also marked the shift from the new world order optimism at the start of the final decade to the new world disorder pessimism by the close of the twentieth century. The net result was to privilege domestic over international concerns even more in structuring the decision incentives of the administration and Congress". (THAKUR, 2006, p. 53)

A lembrança da Somália para o então governo Clinton era de que uma missão sem motivos estratégicos ou políticos, com mandato de curta duração e tarefas bem delimitadas, que havia resultado em um grande desgaste político interno, cujos maiores dividendos eram provenientes das imagens em tempo real dos jovens soldados americanos mortos cruelmente em Mogadishu.

Do lado oposto, estava a experiência da ONU que desfrutava de um momento de revitalização, principalmente da atuação do Conselho de Segurança, que até aquele momento esteve paralisado pelo entorno político-estratégico do conflito bipolar. A Organização, representante máxima do multilateralismo, havia pela primeira vez conduzido a aprovação de uma intervenção humanitária, por meio de resolução unânime do CS, que invocava o Capítulo 
VII de sua Carta constitutiva alegando que a situação na Somália ameaçava a paz e a segurança internacionais.

O desencontro de perspectivas entre a Organização e as grandes potências, com especial referência ao recrudescimento da postura norte-americana com relação a novas intervenções, foi determinante para a postura cruelmente passiva adotada pelas Nações Unidas. A Organização falhou em prevenir e cessar o genocídio, recusando-se em liderar os esforços para uma mudança no mandato da UNAMIR, já que a justificativa legal para ação poderia também ser proveniente do Capítulo VII. O CS poderia ter determinado que as violações dos direitos humanos em Ruanda justificariam uma ação de imposição, sob o Capítulo VII, por representarem uma ameaça à paz e a segurança internacionais.

Outra alternativa teria sido enfrentar a dura oposição norte-americana e nomear Ruanda como genocídio. Embora não seja possível dizer quais teriam sido os resultados do emprego dessa nomenclatura como efeito político, o que se sabe é que a Convenção contra o Genocídio seria conseqüentemente invocada e seu peso normativo seria pela primeira vez colocado à prova.

O ponto crucial é que mesmo diante da disposição da ONU em tomar esse passo sem precedente invocando a Convenção contra o Genocídio como base para justificar a mobilização do Capítulo VII da Carta da ONU, não havia qualquer agente disposto para tal ação, seja as grandes potências, as organizações regionais ou os países vizinhos ao conflito. Portanto, poderia haver um mandato, mas não armas e soldados dispostos a ultrapassar a linha Mogadishu.

A inércia da sociedade internacional contou também com uma grande aliada - a ausência de pressão para que alguma providência fosse tomada por parte da opinião pública mundial. Diferentemente da Iraque e da Somália, a cobertura da mídia, que teve início após quase um mês de genocídio, não criou a mesma pressão pública sobre os governos das grandes potências. No caso dos EUA, o fantasma do conflito somali impediu que qualquer clamor doméstico se erguesse pressionando a administração Clinton a intervir em Ruanda. "The Western media described what was happening in Rwanda as a genocide, but there was no attempt to pin specific responsibility on Western policy-makers for the killings or to demand military intervention to stop them”. (WHEELER, 2000, p. 238)

Com relação à avaliação dos requisitos básicos propostos por Wheeler, não há dúvidas de que a crise em Ruanda constituía um caso exemplar de emergência humanitária suprema. 
O número assombroso de vidas pedidas de forma cruel e desumana, que nas primeiras seis semanas de genocídio já eram estimadas em mais de trezentas mil. No início de maio, após quase um mês de massacres, o genocídio em curso que duraria 110 dias matava cinco pessoas por minuto, trezentas em uma hora e sete mil e duzentas por dia, chegando ao final desse período com a estimativa de oitocentos mil mortos. A campanha de ódio, cujo slogan era “matar ou morrer”, propagada pela estação de rádio Libres des Milles Collines, colocou ao lado das milícias, a grande massa da população hutu na propagação rápida e frenética dos horrores daquela tragédia.

O princípio de necessidade foi observado, embora muito tardiamente; enquanto o princípio de proporcionalidade foi afetado pela condução vergonhosamente parcial da intervenção pela França. Por fim, os resultados humanitários foram irrisórios se comparados à dimensão das violações dos direitos humanos daquela população. Tudo isso porque os meios empregados pela França na condução de sua missão humanitária não foram consistentes com a justificativa humanitária apresentada pelo governo francês, o que comprometeu seriamente o resultado da intervenção em termos humanitários.

O problema com intervenção francesa em Ruanda é que os motivos não-humanitários por trás da intervenção levaram ao emprego de meios que conflitam com os propósitos humanitários. Uma vez que o governo francês reivindicou a justificativa humanitária, ele adquiriu a responsabilidade de agir segundo esse argumento também na prática. (WHEELER, 2000, p. 239) Contudo, o que se viu foi uma completa dissonância entre os motivos alegados, os meios empregados e o resultado humanitário obtido.

Apesar dessa crítica, Wheeler (2000, p. 235) continua rejeitando a validade das condenações à postura francesa baseadas no modelo de motives-first, pois a prioridade da França justificada em termos humanitários poderia ser de fato a intenção de demonstrar à África e ao resto do mundo que a França ainda poderia rapidamente projetar poder militar no continente, desde que isso não implicasse na escolha e aplicação de meios impróprios para a intervenção. Somado a isso, o autor atenta para o resultado desse estreito foco na motivação que ignora como as mudanças no contexto normativo criaram novas possibilidades para a ação do Estado. O que se perde nessa abordagem, concentrada estritamente nos motivos, é como a França tornou possível, dentro das bases legais e com aprovação da ONU, essa intervenção quando ela havia sido descartada pelo Presidente francês Mitterrand semanas antes. 
O Presidente francês, apoiado por seu Primeiro-Ministro, Édouard Balladur e pelo Ministro da Defesa, François Léotard, havia declarado que a comunidade internacional não poderia agir como força policial global que envia soldados para todos os lugares em conflito, indicando que a França não manteria o papel de poder hegemônico na África. Entretanto, tal posição se tornou progressivamente indefensável diante da crescente pressão doméstica sobre o governo francês. (WHEELER, 2000, p. 235) "In this case, the public clamour that 'something must be done' fitted in well with Mitterrand's desire to support Francophone interests in Africa”. (WHEELER, 2000, p. 237)

O autor reafirma a mudança no contexto normativo que permite novas ações estatais, como a intervenção francesa, mas adverte que, neste caso, “(...) the point is not that lives were saved, but that more lives could have been saved had France selected military means that were appropriate to its humanitarian claims”. (WHEELER, 2000, p. 239)

\subsubsection{Recobrando as esperanças normativas: a intervenção da OTAN no Kosovo}

Depois do terrível desfecho da Operação Turquoise em Ruanda, o resultado da crise na antiga Yugoslávia, que preocupou policy-makers, ativistas de direitos humanos, jornalistas e acadêmicos durante a década de 1990, terminava acenando para uma disposição ainda maior no comprometimento com normas mais solidaristas.

\footnotetext{
"Operation Allied Force marked a high point in the increasing emphasis on human rights and humanitarian issues which has been a striking feature of international relations in the post-1945 era. For theoreticians of international relations it represented a further remarkable twist in the strange and longrunning association between the supposedly hard-nosed and 'realist' factor of force, and the supposedly soft and 'idealist' factor of international humanitarian and human-rights norms". (ROBERTS, 1999, s/p)
}

Essas esperanças recobradas devem-se ao fato de que, pela primeira vez desde a fundação da ONU, um grupo de Estados explicitamente justificou seu uso da força contra outro Estado em bases humanitárias, em um contexto onde não havia explícita autorização do CS. Mais ainda, a ação da OTAN foi recebida tanto com aprovação quanto com aquiescência pela maior parte da sociedade internacional.

Antecedentes da Intervenção

A dimensão internacional da crise na antiga Yugoslávia foi despertada pelas declarações de independência da Croácia e da Eslovênia em 25 de junho de 1991. O antigo 
Estado da Yugoslávia era formado por seis nações (Sérvios, Croatas, Eslovenos, Montenegro, Macedônios e, mais tarde, Muçulmanos Bósnios) até o período em que Slobodan Milosevic chegou ao poder em 1987 e, junto com os nacionalistas sérvios, iniciou um plano que resultaria na formação da “Grande Sérvia”.

As declarações de independência da Croácia e da Eslovênia deram a oportunidade ideal para que o nacionalismo étnico de Milosevic prosseguisse com seus planos expansionistas da “Grande Sérvia”. Para tanto, o líder sérvio utilizou-se das recordações dos massacres sofridos pelos sérvios na Croácia durante a II Guerra Mundial para manipular o temor dos 600.000 sérvios que viviam na Croácia após a independência do Estado croata. (WHEELER, 2000, p. 245)

No início da década de 1990, mais especificamente de junho de 1991 a abril de 1992, a Sérvia entrou em guerra com a Croácia. A sociedade internacional manteve-se distante dos ataques de Milosevic à Croácia e, numa resposta opaca, apenas condenou os ataques, sem qualquer sinalização ao governo de Belgrado de que não seriam admitidos excessos ou violência para a delimitação das fronteiras da antiga Yugoslávia.

A posição parcimoniosa dos membros da ONU com relação à situação nos Bálcas devia-se aos temores de que eles fossem interpretados como interventores nos assuntos internos de um país soberano, juntamente com os temores de que qualquer ação mais dura pudesse incentivar movimentos de secessão. (WHEELER, 2000, p. 247)

Nessa luta entre o princípio da manutenção da integridade territorial dos Estados e o direito à autodeterminação, dois dos princípios de legitimação da sociedade internacional, o líder sérvio conseguiu espaço para talhar enclaves sérvios etnicamente puros na Croácia, a ponto de que ele até aceitasse o acordo de Dayton e a presença de uma força de manutenção da paz da ONU, em janeiro de 1992. Em 1995, Milosevic envolveu-se num conflito com a Bósnia, após esse país ter declarado sua independência. O fechamento desse terrível capítulo de violações de direitos humanos foi o estímulo para que o ditador se voltasse para o Kosovo.

As províncias autônomas do Kosovo e Vojvodina, sempre foram os objetivos principais de Milosevic. O primeiro ataque de Milosevic ao Kosovo foi jurídico, dois anos após chegar ao poder. Milosevic suspendeu os direitos constitucionais que a província havia conquistado, sob a constituição de 1974, e plantou as raízes do que viria a ser o posterior conflito no Kosovo em 1994-95. 
Desde que Milosevic suspendeu os direitos constitucionais dos albaneses, adquiridos sob a Constituição de 1974, o clima de tensão na província era crescente. O referendo realizado em 1991, pelo grupo de articulação política Liga Democrática do Kosovo (Democratic League of Kosovo-LDK) refletia toda a insatisfação da população albanesa com a condição de provincía na Sérvia. No referendo, dos oitenta e sete por cento de votantes, mais de noventa e nove por cento declarou apoiar a independência do Kosovo. Entretanto, o líder da Liga, Ibrahim Rugova, não acredita nos resultados de um rompimento violento com a Sérvia, pois para ele qualquer processo de separação que não fosse negociado com a Sérvia produziria um terrível retrocesso sérvio contra os albaneses. (WHEELER, 2000, p. 257)

O líder Rugova foi marginalizado por sua posição de conciliação com a Sérvia, o que acabou enfraquecendo o poder da Liga e favorecendo abordagens mais radicais com relação à questão nacional. Nesse contexto, foi criado o Exército de Liberação de Kosovo (Kosovo Liberation Army) que adentrou a cena política defendendo uma campanha de bombardeio aos alvos sérvios. A campanha teve início em 1998, quando os primeiros ataques foram lançados. O Exército sérvio respondeu com o uso de armas pesadas e poder aéreo, que após um ano já havia destruído inúmras vilas na província, causando a expulsão de centenas de milhares de kosovares de suas casas. (WHEELER, 2000, p. 258)

Limpeza étnica, o veto e a ação da OTAN sem autorização expressa da ONU

A administração Clinton rapidamente condenou a expulsão forçada dos kosovares, posição apoiada pelo CS na Resolução 1160, de 31 de março de 1998, que demandava o fim da violência de ambos os lados. Nenhum dos membros votou contra a resolução, mas muitos, notavelmente a Rússia e especialmente a China (que se absteve) expressaram suas reservas sobre a intervenção do CS no que eles consideravam um assunto da jurisdição da República Federal da Yugoslávia (FRY).

A limpeza étnica do Kosovo não atraiu o interesse da mídia, como já havia acontecido em Ruanda. O responsável por trazer a questão da limpeza étnica do Kosovo à tona, incitando que alguma providência fosse tomada, foi o governo inglês, na figura do então PrimeiroMinistro, Tony Blair, e do Ministro das Relações Exteriores, Robin Cook. Os dois lideraram o movimento que conferia ao Reino Unido e a Aliança do Atlântico Norte (OTAN) a tarefa de cessar a limpeza étnica no Kosovo. (WHEELER, 2000, p. 259) 
Apesar das manifestações de defesa do governo inglês à intervenção da OTAN no Kosovo, duas questões estavam sendo consideradas com preocupação pela Organização. A primeira referia-se à apreensão de que o uso da força da OTAN pudesse ser considerado uma ação do Exército de Libertação do Kosovo; a segunda questão, por sua vez, estava relacionada ao fato de que a Organização não queria agir para apoiar a causa da secessão no Kosovo. (WHEELER, 2000, p. 259-60)

Essas preocupaçãoes sustentavam a postura de cautela da OTAN com relação a intervir na província. Contudo, diante da escala do contra-ataque sérvio aos vilarejos albaneses, a pressão para uma ação da Aliança contra os sérvios tornou-se insustentável. Uma vez decidida a agir, a OTAN se viu sem a autorização do CSNU. Até aquele momento, o CS já havia aprovado, no fim de 1998, a Resolução 1199, em resposta ao crescimento das mortes dos civis no Kosovo, mas embora a resolução tenha sido aprovada sob o capítulo VII, não havia nenhuma determinação explícita do uso de “all necessary means” para lidar com a ameaça à paz e à segurança devido à deterioração da situação no Kosovo.

O poder de veto entrou mais uma vez em ação no CS, impedindo que uma resolução mais incisiva do que a Resolução 1199 fosse aprovada, como pretendia o Reino Unido e os Estados Unidos. Em consultas informais do CS, Rússia e China afirmaram que vetariam qualquer coisa que legitimasse o uso da força contra o regime de Milosevic, o que resultou na ação da OTAN a partir da Resolução 1199, mesmo sem que este documento autorizasse expressamente o uso da força. (WHEELER, 2000, p. 261)

Os ataques aéreos da OTAN contra os alvos sérvios foram iniciados no início de 1998, justificados nos termos das resoluções 1160 e 1199 do CSNU. Logo após o início dos ataques da OTAN, Milosevic concordou com um acordo de cessar-fogo, assinado no "October Agreement” (Acordo de Outubro) de 1998. O problema foi a falha desse Acordo em incluir a população albanesa em suas discussões, o que gerou um forte ressentimento com o fato de que o Acordo de Outubro havia conferido à população da provincía menor autonomia do que eles possuíam sob a Constituição Yugoslava de 1974. Esse ambiente de insatisfação da população albanesa resultou em nova ofensiva do Exército de Liberação do Kosovo, que foi respondido com a retomada da limpeza étnica pelas forças sérvias na província albanesa.

Diante do recrudescimento da violência no Kosovo, uma nova proposta de acordo de paz começou a ser discutida na França, em Ramboilet. As negociações de paz no Kosovo sempre esbarraram no desafio fundamental de conciliar o respeito à integridade territorial da Sérvia com a demanda por independência dos albaneses do Kosovo. Dessa vez não havia sido 
diferente, as negociações na França sem qualquer acordo, encerreram-se em 15 de março de 1999, seguidas por uma nova campanha para a limpeza étnica no Kosovo.

Após o término da negociação frustrada de Ramboilet, a OTAN decidiu lançar os ataques aéreos contra a FRY em 23 de março de 1999. Em seus discursos, tanto os representantes do governo dos Estados Unidos quanto do Reino Unido afirmaram que o Ocidente tinha uma responsabilidade moral de parar as terríveis atrocidades que aconteciam no Kosovo. O argumento de responsabilidade moral, empregado pelos governos inglês e americano, foi duramente questionado pelo governo russo, que acusou a ação da OTAN no Kosovo como uma medida para a expansão da esfera de influência norte-americana nos Bálcãs. Essa desconfiança levantou a questão de quanto as justificativas dos americanos e ingleses equacionavam-se com seus motivos para ação.

Apesar das suspeitas, Wheeler afirma que nem a Rússia nem outros críticos conseguiram apresentar qualquer evidência convincente que comprovasse a acusação de que motivos tradicionais de realpolitik explicavam a Operação da Força Aliada (Operation Allied Force). Ao contrário, as evidências apontavam que este era um caso onde a questão para o uso da força havido sido a crença do Primeiro-Ministro inglês, Tony Blair, e do Presidente norte-americano, Bill Clinton, de que essa era uma guerra justa. (WHEELER, 2000, p. 267)

O próprio Wheeler elenca os quatro argumentos “racionais” usados pelos governos ocidentais para justificar a ação da OTAN: 1) a ação pretendia evitar uma catástrofe humanitária iminente; 2) a credibilidade da OTAN estava ameaçada; 3) a limpeza étnica não poderia ser permitida na Europa, já que isso significaria uma ameaça de longo-prazo à segurança européia; e 4) o uso da força da OTAN estava em conformidade com as resoluções existentes do CS. (WHEELER, 2000, p. 265)

O Primeiro-Ministro inglês, Tony Blair afirmou que não havia conflito entre defender valores humanitários e proteger interesses nacionais. "Our actions are guided by a (...) subtle blend of mutual self-interest and moral purpose in defending the values we cherish (...) values and interests merge”. (BLAIR, 1992, apud WHEELER, 2000, p. 267) O que, segundo Wheeler, corrobora o argumento solidarista de que existe uma mútua compatibilidade entre ordem e justiça, partindo do fato de que os interesses nacionais não são dados, mas construídos. Dessa maneira, a afirmação de Blair demonstrava que ele havia reconstruído os interesses britânicos, com vistas a refletir sua visão da Inglaterra como um Estado socialdemocrata comprometido a defender, pela força se necessário, normas de direitos humanos aceitas internacionalmente. (WHEELER, 2004, p. 267) 
Ajuda pelos ares: os ataques aéreos como estratégia de evitar baixas

Apesar da OTAN ter recorrido à força para cessar a limpeza étnica no Kosovo, a estratégia da Aliança em utilizar ataques aéreos como instrumento de ajuda levanta uma série de questões controversas e características da problemática das intervenções. A primeira delas foi a razão para o uso dos bombardeios. Os policy-makers ocidentais, em especial os americanos que conviviam com o fantasma da Somália, queriam evitar os riscos e os custos de usar as tropas em campo.

O problema é que os bombardeios da OTAN, embora tenham sido significativos, foram um fator decisivo para que Milosevic intensificasse a barbárie contra os kosovares. Dentro de semanas após o início dos bombardeios, milhares de kosovares albaneses foram mortos; mais de meio milhão foram expulsos de suas casas, tornando-se refugiados nos países vizinhos; e centenas de milhares encontravam-se como deslocados de guerra internamente no Kosovo. (WHEELER, 2000, p. 269)

A estratégia com ínfimo risco de baixas dos soldados ocidentais da Aliança havia, num efeito quase que inversamente proporcional, acelerado a limpeza étnica no Kosovo. Segundo Wheeler, a vontade política na Aliança poderia ter formado uma grande força expedicionária a partir da Macedônia e da Albânia, sinalizando a Milosevic que a OTAN estava defendendo seriamente os direitos humanos. De acordo com o autor, isso poderia ter sido suficiente para persuadir Milosevic a negociar seriamente sobre o Kosovo, e provavelmente teria evitado a guerra, que a OTAN foi praticamente obrigada a travar depois de ter falhado em evitar uma emergência humanitária pelo uso do poder aéreo e o maior êxodo de refugiados desde a II Guerra Mundial na Europa. (WHEELER, 2000, p. 270)

As tropas da OTAN nunca atingiram deliberadamente os civis kosovares, pois a estratégia dos bombardeiros, com equipamentos de alta precisão, pretendia evitar os danos colaterais à população civil. Entretanto, quando as forças da OTAN encontram-se sob pressão por resultado, os bombardeios em alvos de infra-estrutura na FRY resultaram no aumento do número de civis sérvios mortos. A partir disso, o caráter moral da campanha de bombardeio, que havia sido criticado desde o início da campanha da Aliança, foi ainda mais maculado pelas bombas perdidas que atingiram as áreas civis. ${ }^{38}$

\footnotetext{
${ }^{38}$ Os bombardeios da OTAN também causaram uma catástrofe diplomática quando atingiram a embaixada chineses em 07 de maio de 1999. Cf. em WHEELER, 2000, p. 271.
} 


\section{Apontamentos finais}

A intervenção da OTAN no Kosovo é emblemática porque pela primeira vez, desde a criação da Carta da ONU, os sete membros do CS legitimaram ou foram aquiescentes com relação ao uso da força em bases humanitárias, num contexto em que não havia autorização expressa do Conselho. A rejeição da draft resolution que a Rússia havia proposto, articulando as normas pluralistas que haviam dominado os debates do CS durante a intervenção da OTAN na antiga Yugoslávia e pedindo a condenação da OTAN, foi histórica. (WHEELER, 2000, p. 281)

Apesar dessa votação histórica, Wheeler afirma que o caso do Kosovo é um precedente legal limitado como intervenção humanitária unilateral, já que os membros da OTAN justificaram sua ação por meio das resoluções já aprovadas sobre o caso, embora sem mandato de uso da força, sob o Capítulo VII. Essa estratégia poderia plausivelmente ser invocada num contexto futuro por outros Estados em que o CS já tivesse adotado as resoluções do Capítulo VII, identificando os abusos de direitos humanos de um governo como uma ameaça à paz e à segurança internacional, e onde a ameaça ou o uso do veto impede o CS de autorizar o uso da força. Essa opção de restringir o direito legal de intervenção humanitária unilateral a situações onde o Conselho já adotou as resoluções do Capítulo VII poderia reduzir o perigo dos Estados decidirem por eles mesmos quando a intervenção humanitária é permitida. (WHEELER, 2000, p. 293)

O ponto crucial dessa votação é como explicar que a draft resolution da Rússia, que questionava a ação da OTAN e pedia ao CSNU a condenação da ação da OTAN tenha sido recusada com o apoio de cinco Estados não-ocidentais. De um lado, a resposta realista alega que é que o CS é uma arena de poder político na qual o forte manipula o mais fraco, e onde todos os membros estão engajados em barganhas estratégicas para ganhar apoio em suas posições. Nessa leitura, portanto, os votos contra a draft resolution russa pelo grupo de Estados não-ocidentais podem ser explicados pela pressão exercida pelos Estados ocidentais.

A explicação solidarista para essa votação é que os Estados membros não-ocidentais se sentiram constrangidos em não fazer nada sobre a situação no Kosovo, a não ser apoiar tacitamente a ação da OTAN. Ao mesmo tempo, em que esses países não foram capazes de defender o caso publicamente, eles mostraram, por meio de seus votos, que eles entendiam 
que o contexto político dentro do Conselho tinha forçado a OTAN a agir sem a autorização da ONU. (WHEELER, 2000, p. 291)

O contra-argumento solidarista à intepretação de que a recusa da proposta russa foi baseada na política de poder dentro do CSNU entende que é preciso diferenciar as ações que são aquiescidas porque são considerações de poder bruto, daquelas que são aceitas relutantemente por causa do humilhante poder das normas humanitárias, e aquelas validadas porque são moralmente aprovadas. Nesse caso, a recusa da proposta russa pelos Estados nãoOcidentais poderia ser interpretada como a aquiescência ao humilhante poder das normas humanitárias. (WHEELER, 2000, p. 290-1)

Com relação à avaliação da legitimidade da intervenção humanitária da OTAN no Kosovo, a situação dos albaneses do Kosovo que estavam sendo dissimados pela limpeza étnica promovida pelo Presidente da Sérvia, Slobodan Milosevic, é amplamente considera como uma emergência humanitária suprema. Independentemente dos motivos nãohumanitários que levaram a OTAN a intervir na província kosovar, a intervenção da Aliança observou o primeiro critério básico para que a missão possa ser considerada legitimamente humanitária.

A avaliação do recurso à força como último recurso não é consensual, já que alguns analistas acusam a OTAN de desistir muito rapidamente da negociação. Wheeler observa que o uso da força foi adequado diante das frustantes negociações de Rambouillet. Além disso, o desafio para aqueles que afirmam que a OTAN usou a força sem exaurir as alternativas de paz é mostrar que havia uma estratégia não-violenta que poderia ter estabelecido as condições para a proteção dos direitos humanos no Kosovo. Embora a falta de vontade política dos líderes ocidentais tivesse conduzido a situação ao grau de violência que só a aplicação de força externa poderia solucionar. Os temores em incentivar movimentos separatistas de secessão da Aliança contribuíram para que Milosevic conseguisse colocar o seu plano de limpeza étnica em andamento no Kosovo. Lembrando que o Presidente sérvio já havia inflingido danos humanitários irreparáveis à população civil da Croácia e da Bósnia. (WHEELER, 2000, p. 283)

O requisito da proporcionalidade do uso da força não foi observado nessa intervenção, já que os ataques aéreos não foram adequados ou proporcionais ao tipo de violência do conflito e, embora possam ter contribuído, não foram decisivos para persuadir o Presidente 
sérvio a aceitar um plano de paz, proposto pelos Estados Unidos e pela Rússia. ${ }^{39} \mathrm{O}$ acordo assinado em junho de 1999 determinou a retirada de todas as forças sérvias do Kosovo e o emprego de uma força multinacional, liderada pela OTAN, que possibilitou o retorno dos refugiados para suas casas onze semanas depois do início dos bombardeios. (WHEELER, 2000, p. 273)

A recusa dos governos da Aliança em lançar mão das tropas militares em campo e a intenção de garantir que a operação seria livre de baixas resultou na escolha de meios impróprios e inadequados para impedir a limpeza étnica na província kosovar. Novamente, a condição de casualty free foi a condição determinante da intervenção, já que os motivos humanitários da ação estavam subordinados a essa condição.

A intervenção humanitária da OTAN no Kosovo sob o critério do resultado humanitário positivo precisa ser avaliada a partir da perspectiva de curto e longo-prazo, mas mesmo sob essa distinção é preciso enfatizar a complexidade do caso do Kosovo. Na perspectiva de curto-prazo, por exemplo, os meios utilizados pela OTAN para parar a limpeza étnica da Operação sérvia Horseshoe claramente a acelerou, demonstrando os limites do poder aéreo como meio de salvamento humanitário. Por outro lado, os bombardeios que falharam em evitar uma catástrofe humanitária contribuíram para a produção de um acordo político, que permitiu que os refugiados kosovares voltassem às suas casas, com uma substancial de autonomia política que lhes teria sido negada na ausência da intervenção da OTAN.

Desse modo, ainda que a intervenção da OTAN no Kosovo tenha tido sucesso em restaurar os direitos políticos e civis dos albaneses, que a política de repressão de Milosevic havia suprimido, ela falhou em impedir uma nova ronda de limpeza étnica, com milhares de sérvios temendo uma vingança dos albaneses. "Far from creating the conditions for a new multiethnic polity in which Serbs and Albanians live under the protection of the rule of law, KFOR was unable in the early months to protect Serbs who now found themselves on the receiving end of a new order of ethnic apartheid”. (WHEELER, 2000, p. 274)

\footnotetext{
${ }^{39}$ De acordo com Wheeler, Milosevic resolveu aceitar o acordo de paz proposto pelos Estados Unidos e pela Rússia pelos seguintes fatores: o temor de perder o apoio russo contra o Ocidente, já que a Rússia pretendia assegurar um acordo que lhe desse um papel político e militar no Kosovo; o receio de que a OTAN decidisse usar forças militares em campo, o que foi sinalizado um mês antes da assinatura do acordo; e, a alteração dos resultados militares de sua ofensiva, já que as forças sérvias estavam enfrentando perdas substanciais. Esses fatores persuadiram muito mais Milosevic do que propriamente os bombardeios. Cf. em WHEELER, 2000, p. 273.
} 
Não por coincidência o fim da limpeza étnica no Kosovo repetiu o mesmo trágico fim do genocídio em Ruanda. Do mesmo modo que a ONU não foi capaz de impedir a inversão de papéis entre tutsis e hutus, após a intervenção francesa, a ONU e a OTAN falharam em impedir a continuação das graves violações dos direitos humanos entre sérvios e albaneses nos Bálcas. A falta de comprometimento com um mandato de longo-prazo novamente minava as possibiliades de construção de novas relações sociais em que o respeito aos direitos básicos fossem garantidos internamente.

\section{2. É possível falar em uma ‘expansão da ambição normativa' relacionada à justiça na sociedade internacional?}

\subsubsection{Normas e legitimidade: possibilidades de novo contexto normativo na sociedade internacional}

A possibilidade de considerar a expansão da ambição normativa solidarista da sociedade internacional, a partir da década de 1990, em relação às intervenções humanitárias, em particular, e às demandas por justiça, está diretamente relacionada ao valor das normas e ao papel que elas exercem em relação à legitimidade de certas práticas e padrões de comportamento.

Uma norma define o padrão de comportamento amplamente prevalecente, e no caso de ser definida eticamente, esta norma constitui “(...) a pattern of behaviour that should be followed in accordance with a given value system; that is, to refer to the moral code of a society: a generally accepted standard of proper behaviour”. (THAKUR, 2006, p. 11)

As normas coletivas, por sua vez, definem-se pela “(...) the social identity of actors while simultaneously constituting the rules of the game for regulating their social behaviour". (THAKUR, 2006, p. 12) O comportamento social dos Estados no jogo internacional baseado nessa lógica de normas coletivas, geralmente institucionalizadas pelas leis do Direito Internacional, justifica a existência de uma sociedade internacional, mesmo perante a ausência de uma instância coercitiva acima dos Estados soberanos; e a observância das leis internacionais, mesmo que isso não lhes possa ser imposto.

De acordo com Charles Manning, o processo diplomático atual representa esse jogo, e como em qualquer outro jogo, ele necessita de regras, e da obediência a essas regras. Essas práticas, portanto, não teriam existência real, e sim fariam parte do que este autor chama de 
public imagination. (MANNING, 1975, apud WHEELER, 2000, p. 22) Martin Wight, por exemplo, afirma que a marca que define a sociedade de Estados é o reconhecimento recíproco da soberania, cuja existência não está ligada à personificação física, mas à existência de significados intersubjetivos compartilhados. (WIGHT, 1966 apud WHEELER, 2000, p. 22)

"Shared ideas, expectations, and beliefs about appropriate behaviour are what give the world structure, order and stability". (FINNERMORE, Martha; SIKKINK, Kathryn, 1998, p. 894). Portanto, uma vez que significados intersubjetivos compartilhados estabeleçam o comportamento apropriado aos Estados, isso refletirá em ordem e estabilidade para a sociedade internacional. No caso da sociedade internacional pluralista, os significados intersubjetivos ou a public imagination compartilhada referem-se ao princípio de soberania, que define o Estado e a "the norm of non-intervention, a logical corollary of that principle, (that) helps to regulate the interactions of states in international relations”. (THAKUR, 2006, p. 12)

Os Estados atuando como agentes, por meio de suas interações, estabelecem as práticas reconhecidamente legítimas e compartilhadas pela sociedade da qual fazem parte. No caso da sociedade internacional pluralista, a ordem e a estabilidade serão o resultado do reconhecimento recíproco de que a soberania, a não-intervenção e o não-uso da força estabelecem as práticas legítimas para o funcionamento adequado da sociedade e de suas interações.

A questão é que o compromisso com determinadas normas implica em agir segundo essas normas; segundo o padrão de comportamento apropriado que essas normas estabelecem. Como resultado, o comportamento diferente daquele estabelecido pelas normas compartilhadas implicará em constrangimentos, que não serão físicos, mas normativos. (WHEELER, 2002, p. 22) No plano internacional, as normas constrangem e habilitam os atores, estabelecendo “(...) intersubjective meanings that allow the actors to direct their actions towards each other, communicate with each other, appraise the quality of their actions, criticize claims and justify choices.” (WHEELER apud KRATOCHWIL, 2000, p. 05)

A legitimidade e sua relação com a formulação construtivista, ${ }^{40}$ de constrangimento e habilitação proveniente das normas, estão na base do argumento solidarista de Nicolas Wheeler para explicar os novos compromissos normativos que levaram à sociedade de

${ }^{40}$ Conferir em: WENDT, A. Social Theory of International Politics. Cambrigde: Cambridge Universtity Press, 1999. 
Estados a reconhecer a legitimidade do uso da força contra Estados que violam gravemente os direitos humanos, mesmo sem a autorização da ONU.

O argumento de Wheeler é que no plano internacional também há espaço para as considerações de legitimidade, e não só de poder. O autor refuta a idéia realista que coloca poder e legitimidade em um relacionamento de antítese, utilizando o argumento de Inis Claude de que os dois conceitos são complementares, desde que "observe the legitimacy of power is the power of legitimacy; rulers seek legitimization not only to satisfy their consciences but also to buttress their positions”. (CLAUDE, 1966, apud WHEELER, 2002, p. 04)

Wheeler vai além do argumento de Claude afirmando que a legitimidade é relevante não só porque ela pode sustentar posições, mas porque ela é constitutiva da ação internacional, na medida em que “(...) the state actions will be constrained if they cannot be justified in terms of a plausible legitimating reason”. O “poder da legitimidade” em constranger a ação dos Estados é, nesse sentido, um argumento mais poderoso do que Claude inicialmente desenvolve. (WHEELER, 2002, p. 04)

A necessidade de buscar a legitimidade de uma ação no plano internacional justificando-a por meio de uma base legítima de motivos é o primeiro ponto controverso sobre a legitimidade. Para Edward Carr, em Vinte Anos de Crise, os Estados são sempre capazes de criar legitimidade e teorias da moralidade internacional conveniente a eles mesmos. Portanto, a legitimidade seria sempre o produto de Estados poderosos adotando conscientemente aqueles princípios morais que servem aos seus interesses. Para este autor, não se trata de hipocrisia moral, já que os atores podem sinceramente acreditar nos princípios que eles professam. O problema é que esses princípios, supostamente absolutos, podem não ser princípios em si, mas reflexos inconscientes da política nacional, baseada na interpretação particular do interesse nacional num determinado momento. (CARR, 1939, apud WHEELER, 2000, p. 06-7)

A resposta solidarista de Wheeler vem no sentido de afirmar que existe claramente um relacionamento entre poder e normas, mas que essa relação não é unidimensional como Carr entende, visto que, uma vez estabelecida, uma norma servirá para constranger até mesmo os mais poderosos Estados no sistema internacional. Nessa perspectiva, a noção de legitimidade internacional não está sob o controle de agentes individuais, porque o leque de razões legitimadoras que um ator pode invocar, mesmo os mais poderosos, é limitado pela 
moralidade prevalecente, na qual essas razões encontram-se. (SKINNER apud WHEELER, 2000, p. 62)

Wheeler utiliza a formulação de Pierre Bourdieu de que os jogadores reproduzem o jogo em que estão inseridos, sem que isso seja necessariamente um produto de cálculo consciente para contrapor a perspectiva realista, que afirma que os líderes dos Estados reconhecem a necessidade de justificar suas ações tendo em vista esse conjunto de normas compartilhadas, não porque estejam comprometidos normativamente com essas normas, mas sim pela tentativa de evitar a censura moral e as sanções. Contrariamente à posição realista, a formulação de Bourdieu entende que os Estados estão socializados numa série de predisposições que não são questionadas, e que eles podem sim seguir seus interesses, mas o modo como eles os definem é formado pelas normas que prevalecem na sociedade de Estados. (BOURDIEU, 1987, apud WHEELER, 2000, p. 23) “(...) Rules intersalised as legitimate, either because of the source or the procedure by which they were constituted, help to define the actor's self-interest”. (THAKUR, 2006, p. 07)

A legitimidade e sua relação com a formulação construtivista ${ }^{41}$ de constrangimento e habilitação proveniente das normas estão na base do argumento solidarista de Nicolas Wheeler para explicar os novos compromissos normativos que levaram à sociedade de Estados a reconhecer a legitimidade do uso da força contra Estados que violam gravemente os direitos humanos, mesmo sem a autorização da ONU. (WHEELER, 2000)

“(...) an increasingly internationalized human conscience and a growing sense of an international community into a new normative architecture of world order. There is growing recognition of the authority of international consensus over individual state consent as the foundation of legal obligation”. (THAKUR, 2006, p. 244)

\subsubsection{Investigando as intervenções humanitárias como norma global}

O argumento de que a legitimidade das intervenções humanitárias, a partir da década de 1990, demonstra que uma estrutura normativa mais solidarista está sendo construída na sociedade internacional não é consensual. O fato das intervenções humanitárias terem ganhado espaço na escolha política internacional dos anos 1990 não impede que se questione esse argumento. Nessa seção, a criação e as limitações do processo de desenvolvimento e

\footnotetext{
${ }^{41}$ Conferir em: WENDT, A. Social Theory of International Politics. Cambrigde: Cambridge Universtity Press,
} 1999. 
maturação de uma nova norma relacionada à legitimidade das intervenções humanitárias serão analisadas.

Ramesh Thakur, por exemplo, questiona o quanto essa norma recém criada que legitima as intervenções humanitárias pode ser considerada global. O primeiro questionamento do autor é sobre como considerar a norma da intervenção humanitária perante o que ele chama de inconsistência normativa, ou seja, a desigualdade na aplicação de uma mesma norma, como a da intervenção e não-intervenção, em diferentes lugares e casos. (THAKUR, 2006, p. 276)

O posicionamento solidarista em relação à acusação de inconsistência na aplicação da regra da intervenção humanitária é defender a necessidade de fazer uma distinção entre coerência e consistência. Nesse caso, a coerência é definida por uma estrutura que estabeleçe que os casos sejam tratados de igual maneira, mas que, ao mesmo tempo, reconhece que isso não significa que todos os casos possam sempre ser tratados da mesma forma. Dependendo do nível de solidariedade na sociedade de Estados é necessário não só que os abusos de direitos humanos sejam expostos ao escrutínio e censura internacional, mas que os governos que violam tais direitos paguem um alto preço em termos diplomáticos, políticos e econômicos. (WHEELER, 2000, p.305)

“(...) selectivity is not a threshold condition for an intervention to count as humanitarian, because the failure to act in one place to end human rights abuses does not disqualify other interventions that do end such abuses". "It is important to distinguish between interventions that are selective because of reasons of prudence and those are selective because of selfish interests". (WHEELER, 2000, p.305)

Ainda considerando o processo de criação e desenvolvimento de uma nova norma, Thakur reafirma a necessidade de haver um norm entrepreneur (empreendedor da norma), que lidere o processo de contestação normativa que dará origem a uma nova norma. Dessa perspectiva, não haveria sucesso na promoção dessa nova norma sem uma ação de empreenderorismo. Mas, quem seria o norm entrepreneur das intervenções humanitárias?

"The rule of law ideal has been diffused from the West to become as international norm. It asserts the primacy of law over the arbitrary exercise of political power by using law to tame power; the protection of the citizen from the arbitrary actions of the government by making both, and their relationship to each other, subject to impersonal and impartial law; and the primacy of universalism over particularism through the principle of equal in law, whereby individuals coming before the law are treated as individuals, divorced from their social characteristics”. (THAKUR, 2006, p. 279) 
A citação de Thakur parece indicar claramente o Ocidente como o norm entrepreneur das intervenções humanitárias. Em oposição ao norm entrepreneur, geralmente há um opositor que pretende vetar ou bloquear a substituição de uma norma por outra. Para que a nova norma não seja bloqueada a ponto de ser impedida de existir, esse opositor não pode combinar poder estrutural e uma coalizão. (THAKUR, 2006, p. 279) O papel de opositor à norma da intervenção é atribuído com freqüencia aos Estados não-ocidentais e países em desenvolvimento, para os quais a norma da não-intervenção ainda permanece como imperativo moral e a norma da intervenção como uma ameaça à sua soberania. No geral, o sentimento de desconfinça e o temor de imperialismo têm sustentado essa percepção de que eles seriam os opositores dessa norma da intervenção.

O sentimento de vitimização e o desejo de restituição dos países em desenvolvimento; a crença de que a ordem estado-cêntrica tinha provido proteção para muitos dos Estados mais fracos e recém-criados após o período de descolonização; e os constrangimentos do mecanismo da balança de poder que o período de conflito bipolar havia colocado sobre as políticas externas expansionistas foram as bases para que os países em desenvolvimento defendessem com veêmencia o princípio da soberania e as normas da não-intervenção e nãouso da força até o fim da Guerra Fria. (FOOT, 2003, p. 07)

Após o fim da II Guerra Mundial, os novos Estados formados a partir do processo de descolonização engajaram-se simultaneamente na construção do Estado, da nação e do desenvolvimento econômico. A soberania pelo reconhecimento foi a base para a busca de todos esses objetivos. "The path-dependence of their colonial history offers a clue as to why sovereignty and its correlative norm of non-intervention are more deeply internalised in the developing country elites than their counterparts in the West”. (THAKUR, 2006, p. 275)

Sendo assim, ao lado do desejo de permanecerem associados a esses princípios e normas do passado, ainda presentes nas instituições do sistema internacional, algumas oportunidades para a reforma e melhora das condições de inserção desses países - referentes às desigualdades de poder, falhas na representação, entre outros - surgiram com o fim do conflito bipolar e abasteceram neles uma série de expectativas que apontam numa direção mais liberal. (FOOT, 2003, p. 07)

Além disso, mesmo que esse conjunto de países fosse considerado o opositor a norma da intervenção humanitária, faltaria o poder estrutural e uma coalizão para que eles de fato vetassem ou bloqueassem a emergência dessa norma. Nessa “disputa”, o poder estrutural e as melhores condições para uma coalização estariam do lado do norm entrepreneur ocidental. 
"The implicit but clear assumption is that when Western and non-Western values diverge, the latter are in the wrong and it is only a matter of working on them with persuasion and pressure for the problem to be resolved and progress achieved”. (THAKUR, 2006, p. 277)

Então, supondo que seja realmene possível considerar que existe de fato o entrepreneur e o opositor a essa norma, em que medida, é possível afirmar que existe de fato uma disputa entre eles? O primeiro elemento que questiona a existência desta “disputa” é a discordância a respeito existência de contestação normativa da não-intervenção por ambas as partes. Para Inis Claude, por exemplo, a intervenção tem se tornado uma nova norma em um clima no qual a não-intervenção aparece como um dever de negligência, que requer explicação e desculpas. (CLAUDE, 2000, apud THAKUR, 2006, p. 254) Thakur discorda dessa contestação normativa seja pelos opositores à norma da intervenção, seja até por seus entrepreneurs.

\footnotetext{
"The norm of non-intervention may be dented slightly, but is still intact. The number of cases where outsiders could have intervened but did not - the Democratic Republic of Congo, Sierra Leone, Darfur, Myanmar and Chechnya, to name just a few - is more than the few cases of intervention. The claim, therefore, that the norm of non-intervention is being replaced by that of intervention is empirically false. (THAKUR, 2006, p. 254)
}

"The contestation reflects competing conceptions of the good life, the proper relationship between citizen and state, historical wrongs and present rights, and correlative rights and obligations”. (THAKUR, 2006, p. 278) Dessa maneira, esse elemento da contestação normativa seria essencial nesse processo que (supostamente) pretende substituir a norma antiga - a não-intervenção - por uma nova norma - a intervenção (humanitária).

Thakur entende que a coerência normativa requer compatibiliade entre um grupo de normas relacionadas, como as normas de uso e não-uso da força, intervenção e nãointervenção nas relações internacionais. (THAKUR, 2006, p. 276) Nesse sentido, essa incoerência com a defesa da norma da intervenção parece indicar uma espécie de concessão tática $^{42}$. No geral, os Estados afirmam o dever moral da intervenção humanitária, baseada em graves violações de direitos humanos, sendo opositores ou favoráveis a essa norma, mas rejeitam na prática a violação da norma da não-intervenção.

\footnotetext{
${ }^{42}$ Ramesh Thakur não está trabalhando com a dimensão externa do que ele denomina concessão tática. Ele trabalha com essa idéia no contexto interno, em que grupos da sociedade civil pressionam seus governos para a adesão das normas internacionais. Apesar disso, a idéia me pareceu bastante aplicável para pensar essa inconsistência entre a defesa retórica da intervenção humanitária como norma e a manutenção prática da norma de não-intervenção. Cf em: THAKUR, 2006, p. 275.
} 
Essa postura contraditória entre o devor moral e a prática política das intervenções humanitárias demonstra que "there is neither a homogeneous international society with respect to human rights and humanitarian concerns, nor a unifying normative architecture. Rather, the reality of norm variation attests to the existence of a polymorphic international society”. (THAKUR, 2006, p. 274)

Além disso, mesmo que a nova norma a respeito das intervenções humanitárias não esteja sendo seguida, não significa que essa norma perde a importância ou seu caráter normativo de que esse seria o padrão de comportamento ideal. Wheeler lembra que a eficácia de uma norma não é medida somente pelo grau de obediência a ela, mas sim pela justificativa dada para as ações e a responsabilização dos Estados que infrinjem tal norma.

\subsubsection{Possibilidades e limites de uma norma da intervenção humanitária}

\section{As Possibilidades}

As limitações da ordem internacional pluralista e o alcance restrito de suas respostas para lidar com a complexidade de algumas questões, como as intervenções humanitárias, parecem indicar a insuficiência das proposições pluralistas no que se refere ao lugar da justiça frente à atual ordem internacional. Essa insatisfação tem gerado, segundo Wheeler (2000), Hurrell (2003) e Welsh (2004), dentre outros, a possibilidade de considerar uma expansão da ambição normativa na sociedade internacional, em especial no que se refere à busca por justiça.

Segundo Andrew Hurrell, as grandes modificações do curso do século XX passaram a desafiar a concepção estreita do que a sociedade internacional poderia e deveria aspirar. Além disso, essas modificações também desafiaram o lugar privilegiado de uma ordem limitada pelo poder político e construída em torno da soberania estatal. Sendo assim, foram essas modificações que possibilitaram que a mudança na estrutura normativa da política mundial em direção a uma concepção de sociedade e ordem internacional de maior alcance, ou seja, mais solidarista em seus princípios e normas fosse proposta. (HURRELL, 2003)

"What states and peoples deem it legitimate to expect from international society or from the much appealed-to international community has increased exponentially. Thus a minimally acceptable notion of order is increasingly held to involve the creation of international rules that deeply affect the domestic structures and organization of states, that invest individuals and groups within states with rights and duties, and that seek to embody some notion of a global common good”. (HURRELL, 2003, p. 32) 
Seria possível, ainda de acordo com esse mesmo autor, identificar uma agenda de justiça global mais coerente, tanto na realidade empírica da política mundial quanto no crescente número de escritos acadêmicos sob a perspectiva da teoria normativa internacional. Essa agenda de justiça global conteria: "The idea that international legal rights, duties, and entitlements should be
respected and acted upon and that wrongdoing be punished wherever it
occurs; and the broader notion that the major international and global social,
political, and economic institutions that determine the distribution of benefits
and burdens should be organized and, if necessary, restructured in
accordance with principles of global social justice". (HURRELL, 2003, p.
32)

A estrutura normativa da sociedade internacional tem se desenvolvido em modos que ajudam a minar os argumentos daqueles que negam a existência de uma comunidade de justiça global, ou daqueles que tomam posições restritivas ou fortemente pluralistas no que se refere à justiça global. A idéia tradicional de ordem, ou seja, aquela baseada na proteção das diferenças societais e de valores associados com a sobrevivência do sistema de Estados, é incapaz de corresponder às demandas dessa nova construção normativa. Rosemary Foot endossa esse argumento quando afirma que os termos do debate entre ordem e justiça têm refletido uma maior ambição e consciência solidarista e que tem havido uma revitalização da visão liberal de que a ordem não pode ser sustentada na ausência de justiça. "It is essential to explore the depth and scope of this presumed solidarism”. (FOOT, 2003, p. 02)

As indicações que levariam à comprovação do argumento de que a estrutura normativa da sociedade internacional tem sido desenvolvida em direção ao maior comprometimento com normas solidaristas são apresentadas sob quatro dimensões por Andrew Hurrell: o conteúdo das normas, a fonte das normas, a justificação e a avaliação das normas e o movimento em direção à implementação mais efetiva dessas normas. (HURRELL, 2003, p. 39-40)

Em contraste com a mera coexistência das normas pluralistas, o conteúdo de normas mais solidaristas envolve esquemas expansivos de cooperação - como a criação e a defesa de valores comuns, que é o caso da promoção dos direitos humanos, autodeterminação ou democracia política - para proteger a paz e a segurança internacionais. (HURRELL, 2003, p. 39)

A fonte e o processo dessas novas normas não estão mais baseadas unicamente na figura do Estado e dependentes do consentimento estatal, como na concepção pluralista 
tradicional. Na concepção solidarista, o processo de criação de normas é aberto ao escopo mais amplo de atores, estatais e não-estatais que trabalham na lógica do consenso e não do consentimento. (HURRELL, 2003, p. 39) O papel desses atores não-estatais, como as ONGs, na criação das normas, na adoção dessas normas pelas estruturas legais internacionais e a emergência de estruturas de autoridade privada, especialmente para os setores particulares da economia global demonstram a emergência de estruturas de governança transnacionais. (HURRELL, 2003, p. 41)

Com relação à justificação e a avaliação das normas, ao lado dos argumentos realistas, de que tanto as normas quanto as leis - formas institucionalizadas das normas - estão sujeitas à manipulação do Estado a favor da realização de seu interesse próprio, Hurrell avalia que o pós-1945 tem visto a emergência de um alcance de princípios acordados internacionalmente respeito pelos direitos humanos fundamentais, proibição da agressão, autodeterminação - que podem alicerçar alguma noção de bem comum mundial e alguma base mais ampla para avaliação de regras específicas, como o uso da força por motivação humanitária nas intervenções humanitárias, autorizadas sob o Capítulo VII da CNU. (HURRELL, 2003, p. 39)

Sérios esforços têm sido feitos para criar elementos de um consenso global sobre certas normas de justiça e mesmo sobre sua implementação. A ONU está agora fortemente associada com uma visão que uma paz duradoura, entre e dentre os Estados, que deve ser baseada nas idéias de justiça. Daquele período de negociação da Carta da ONU adiante, os interesses e ideologias dos principais poderes, incluindo os membros permanentes do CS, formataram as preocupações da ONU com um amplo alcance das questões conectadas à justiça, incluindo questões que afetam as relações dos cidadãos com o Estado. (ROBERTS, 2003, p. 76)

A quarta dimensão do movimento em direção a criação de normas mais solidaristas na estrutura normativa da sociedade internacional é a implementação mais efetiva dessas normas e a variedade de esforços para ir além da observância tradicionalmente muito soft dos mecanismos, dando mais efetividade à ambição normativa dessa sociedade. (HURRELL, 2003, p. 40)

A ênfase na importância das normas e de seus constrangimentos em relação à legitimidade das ações políticas não significa questionar o fato de que o poder importa. O que se pretende é: partindo da premissa de que o poder importa, afirmar que as normas também importam, principalmente no que se refere a um processo tão complexo como a expansão normativa da sociedade internacional. Seria, portanto, altamente equivocado atribuir esse 
processo de mudança normativa à imposição dos Estados mais poderosos do sistema internacional.

Essa mudança na estrutura normativa da sociedade internacional está, segundo Hurrell, intimamente ligada ao poder e à distribuição do poder não só dentro do sistema de Estados, mas também da economia global e da sociedade civil transnacional. A distribuição de poder teve papel determinante na concepção das principais instituições internacionais do século XX, mais notavelmente a ONU e o sistema de instituições econômicas de Bretton Woods. Entretanto, ao lado da incorporação crescente de normas políticas e econômicas liberais ao Direito Internacional e da expansão das práticas das instituições internacionais que refletem uma nova era de hegemonia ocidental, o peso da antiga distribuição de poder parece estar sendo progressivamente diluído pelo impacto das transformações políticas, econômicas e sociais dessa mudança de século. (HURRELL, 2003, p. 34)

A melhor exemplificação dessa mudança estrutural parece estar no papel que as instituições internacionais passaram a exercer para os atores, internacionais e transnacionais, de menos poder e influência nos rumos da política mundial. O diálogo que antes incluía somente os governos e atores centrais agora não pode mais ocorrer sem a inclusão dos diversos jogadores políticos, econômicos e sociais de todas as partes do globo, até mesmo ou principalmente das mais desprivilegiadas. (HURRELL, 2003, p. 35)

Nesses foros, inicialmente moldados pelo poder e influência das potências, é possível observar progressivamente um movimento de empoderamento daqueles atores antes totalmente marginalizados na sociedade internacional. Eles têm sido capazes de usar as plataformas institucionais e explorar os padrões já estabelecidos de argumento legal para promover novas instituições e regras de maior alcance - como o Tribunal Penal Internacional. (HURRELL, 2003, p. 35)

De acordo com Hurrell, a tradução do poder material cru em ação política efetiva é complexa, especialmente nesse ambiente de crescente densidade e complexidade do sistema legal internacional e do processo de globalização, que tornou o processo de criação e institucionalização de novas normas mais difícil de ser controlado ou decidido pelo poder. O autor recorda o exemplo da revolta do mundo colonial contra a dominância do Ocidente, que envolveu uma mudança surpreendentemente bem sucedida em muitas normas políticas e legais dominantes, em especial àquelas relacionadas à conquista e colonialismo, nãointervenção, autodeterminação e igualdade racial. Juntamente com a densidade e complexidade crescente do sistema legal internacional e a globalização abrindo novos canais 
de ação política transnacional, o que é importante é o fato de que o processo de criação de novas normas tornou-se mais difícil para o poderoso controlar. (HURRELL, 2003, p. 35)

De acordo com Roberts, de 1945 (ano de sua criação) adiante, as articulações dos princípios de ordem e justiça da ONU, incluindo o campo dos direitos humanos, não tem sido resultado da dominância por um único poder hegemônico, mas o produto de uma difícil barganha, no qual interesses e justiça não têm habitado categorias separadas, entre Estados com diferentes pontos de vista e tradições. (ROBERTS, 2003, p. 76)

Esse quadro geral de amplas e complexas modificações parece indicar que o atual contexto não permite que, em um mundo interdependente, a omissão frente às obrigações com a humanidade, justificadas pela concentração nos interesses internos dos Estados, permaneça moralmente defensável. Sob um olhar mais específico, a mudança com relação às intervenções humanitárias, principalmente por meio de atitudes mais permissivas quanto à aceitação e legitimidade dessas intervenções, parece fornecer indícios para que se possa relacionar tal fato à expansão solidarista da estrutura normativa da sociedade internacional e aos indícios de existência de uma comunidade de justiça global.

A estrutura normativa da sociedade internacional tem se desenvolvido em modos que ajudam a minar os argumentos e posições restricionistas ou fortemente pluralistas ligadas à idéia de justiça global. Com base nisso, é possível refutar o argumento de Morgenthau de que "the appeal to moral principles in the international sphere has no universal meaning. It is either so vague as to have no concrete meaning that could provide rational guidance for political action, or it will be nothing but the reflection of the moral perceptions of a particular nation”. (MORGENTHAU apud HURRELL, 2003, p. 39) O significado desses princípios morais internacionais pode não ser universal, mas está certamente amplamente difundido no sistema global. (HURRELL, 2003, p. 39)

\section{Os Limites}

Muito provavelmente a maior limitação com relação às intervenções humanitárias refere-se à controversa legalidade e legitimidade da ação unilateral de um único Estado, ou grupo de Estados, que intervêm para cessar abusos de direitos humanos quando não há autorização do CSNU. Wheeler considera que os argumentos humanitários avançaram por meio dos Estados ocidentais desafiando os princípios de legitimidade pluralista, dominantes 
da sociedade de Estados. Como resultado desse avanço, o CSNU se tornou progressivamente mais aberto aos valores solidaristas no início da década de 1990 como um resultado dos Estados ocidentais procurarem a bandeira da legitimidade da ONU para suas intervenções no Iraque $^{43}$ e na Somália. Contudo, a mudança normativa principal nos anos 1990 foi que o CSNU sob pressão dos governos ocidentais - que estavam por sua vez respondendo às demandas de sua opinião pública doméstica - interpretou suas responsabilidades crescentemente sob o Capítulo VII, incluindo, por exemplo, a imposição de normas humanitárias globais. (WHEELER, 2000, p. 289)

A contínua relutância da sociedade de Estados em conceder um direito de intervenção humanitária unilateral a Estados ou organizações regionais representa a voz pluralista que nos remete ao conflito entre ordem e justiça como algo irreconciliável. Wheeler desconfiança desse argumento pluralista que alega que as intervenções humanitárias unilaterais ameaçam a ordem internacional. Segundo ele, a própria sociedade de Estados acredita minimamente que uma doutrina de intervenção humanitária unilateral irá de fato minar os pilares da ordem interestatal. (WHEELER, 2000, p. 295)

"States do disagree over the meaning and priority to be accorded civil, political, economic, and social rights, but theses controversies should not obscure the fact that governments have signed up to legal instruments that commit them to upholding basic standards of humanity. Indeed, no government questions these normative standards, even when breaching them, and the dispute is over the means that can legitimately be employed to enforce theses standards on governments that violate them". (WHEELER, 2000, p. 295)

A proposta solidarista para essa objeção pluralista referente a intervenções humanitáras unilaterais propõe que a sociedade de Estados reconheça as exceções da intervenção unilateral somente quando um Estado ou grupo de Estados puder legitimamente defender suas ações como humanitárias. Esse Estado ou grupo de Estados teria que comprovar, de modo convincente, que o caso trata-se de emergência humanitária suprema e que o uso da força na intervenção satisfará os requisitos de necessidade e proporcionalidade, assim como não haverá contradição entre os motivos e os meios a fim de que se alcance um resultado humanitário positivo. Wheeler reconhece o limite desse grupo de critérios para gerar consensos, em especial diante da complexidade dos casos que não resolvem somente pela questão de se as condições estabelecidas nesses critérios foram satisfeitas. No entanto, isso

${ }^{43}$ Criação das safe havens e no-fly zones, com base da Resolução 688 do CSNU, para salvar os curdos que estavam morrendo de frio e fome nas montanhas do Norte do Iraque, após ofensiva do Presidente Iraquiano, Saddam Hussein. Cf. em WHEELER, 2000, p. 141-171. 
criaria uma estrutura dentro da qual os atores ao menos poderiam discutir os méritos dos argumentos conflitantes. (WHEELER, 2000, p. 295)

Naqueles casos particulares em que um Estado ou um grupo de Estados assumir a responsabilidade por uma intervenção humanitária unilateral, as considerações de poder bruto não poderão ser ignoradas e claramente irão influenciar o nível de sanção a esses interventores , mas o crucial é que os Estados poderosos, ao tentar impedir uma intervenção humanitária unilateral considerada legítima, saibam que eles serão chamados a responder perante a sociedade de Estados ao que Henry Shue chama de "the court of world public opinion”. (SHUE, 1998, apud WHEELER, 2000, p. 296) “Even the powerful do not want to be exposed as hypocrites, and, once a state has legitimated an intervention as humanitarian, its subsequent actions will be constrained by the need to avoid acting in ways that undermine a positive humanitarian outcome”. (WHEELER, 2000, p. 296)

Na proposta solidarista de Wheeler é inaceitável que os membros permanentes do CSNU exerçam o veto em situações onde os Estados pedem autorização ao Conselho e em que haja um apoio internacional significante para a intervenção prevenir ou cessar graves abusos de direitos humanos. (WHEELER, 2000, p. 297) Nesse sentido, caso a sociedade de Estados legitimasse as intervenções humanitárias unilaterais, nas situações em que o CSNU é incapaz de autorizar uma ação, por causa do veto, estaríamos diante de uma nova capacidade coletiva para a imposição de um direito humanitário global. (WHEELER, 2000, p. 298)

O desafio, então, seria criar uma esfera pública global na qual os atores não-estatais tivessem um importante papel no processo de julgar as credenciais humanitárias das intervenções. (WHEELER, 2000, p. 299) Essa esfera pública global seria definida a partir da sociedade civil global, ou seja, do crescente papel e importância que os grupos intermediários auto-organizados conquistaram, relativamente independentes das autoridades públicas e dos atores econômicos privados, no processo de tomada de decisões coletivas em busca de seus interesses e valores, sem restrições de fronteiras estatais. A atuação da sociedade civil global tem adquirido posição de destaque na mudança política da justiça global, principalmente nos processos de desenvolvimento e institucionalização de novas normas. (HURRELL, 2003, p. 37)

A potencialidade normativa da sociedade civil global como uma arena da política que transcende o caráter inside-outside da política tradicional e adapta e provê espaço para novas formas de comunidade política, solidariedade, e identidade está no caráter de arena política aberta e plural para a negociação de regras e normas, baseadas num consentimento genuíno e 
espontâneo, que essa sociedade civil global contém. (HURRELL, 2003, p. 38) No entanto, a ressalva com relação a essa potencialidade normativa da sociedade civil global está no fato de que ela é, antes de tudo, uma arena política como qualquer outra, ou seja, uma arena na qual o bom e o terrível coexistem perfeitamente. Portanto, os argumentos penetrantes feitos pelos movimentos sociais e ONGs para autenticidade e representatividade precisam ser testados e desafiados, já que suas ações também estão sujeitas à manipulação direta de atores poderosos como igualmente acontece no mundo da política inter-estatal. A sociedade civil global enquanto arena política não está livre do perigo de transformar-se em uma arena da política, que Estados e organizações sociais procuram dominar e explorar para legitimar suas próprias ações por poder. (HURRELL, 2003, p. 38)

Essa esfera pública global teria a função de julgar e aprovar as ações unilaterais de intervenção humanitária, com base nesse conjunto de normas de legitimidade da intervenção humanitária unilateral, divididos em requisitos mínimos e adicionais, propostos por Wheeler e apresentados no Capítulo I deste trabalho. Dessa maneira, nos casos futuros em que um governo satisfizesse não só os requisitos mínimos, mas também os adicionais (justificativa humanitária e legalidade pela aprovação da ONU) que estão acima do limite mínimo requerido, a legitimidade coletiva deveria transformar-se em apoio político, econômico e mesmo militar para o Estado interventor, encorajando assim outros governos a arcar com os custos e riscos de uma intervenção humanitária. Entretanto, Wheeler reconhece que a fraqueza dessa abordagem de intervenção é o fato de que ela torna a intervenção humanitária unilateral um direito (right) e não um dever (duty). (WHEELER, 2000, p. 299)

A intervenção humanitária unilateral como um direito atribui aos Estados a liberdade de exercer ou não esse direito e, mais, de colocar seu exercício abaixo de considerações de interesse, o que faz com que os Estados só aceitem "pagar o custo humano” da intervenção, ou seja, correndo o risco de baixas militares somente se acreditarem que seu interesse nacional está em jogo. (WHEELER, 2000, p. 300) Por isso, nenhum governo ocidental realizou uma intervenção para defender os direitos humanos nos anos 1990 a menos que estivesse muito confiante de que o risco de baixas fosse quase zero e nos casos da Índia (1971), Vietnã (1979) e Tanzânia (1979) os Estados agiram para parar as atrocidades, aceitando inlcusive arcar com a baixa de seus soldados, porque seus interesses foram ameaçados.

Considerando que os interesses desses Estados foram ameaçados pela proximidade deles com o local da crise humanitária, uma das possibilidades para esse desafio de persuasão 
dos Estados com relação ao custo de lidar com as baixas militares seria concentrar a responsabilidade nos atores regionais ou sub-regionais de arcar com a imposição do direito humanitário, já que esses Estados vizinhos à crise humanitária teriam uma questão de segurança envolvida em suas considerações dos motivos para intervir. O grande fluxo de refugiados, por exemplo, seria um dos fatores provenientes das crises regionais que carregam o risco de que a violência envolva a totalidade de uma determinada região.

Por seu turno, os últimos três casos de intervenção humanitária - Somália (1992), Ruanda (1994), e Kosovo (1998) - refletem a dificuldade prática e normativa de lidar com essa questão naquelas situações que por maiores que sejam as conseqüências para a segurança regional, os Estados vizinhos não têm condições políticas, militares e econômicas para liderar a ação e, então, é preciso persuadir os líderes dos Estados que estão a milhares de quilômetros de distância das emergências humanitárias, em lugares em que não há interesses, mas vidas de civis inocentes em jogo a pagar os custos de intervir.

"The failure to intervene was driven more by the reluctance of Member States to pay the human and other costs of intervention, and by doubts that the use of force would be successful, than by concerns about sovereignty”. (ANNAN, 1999 apud WHEELER, 2000, p. 300) O cerne da questão nesse caso está em como persuadir e convencer os líderes dos Estados de que eles têm responsabilidade de proteger, uma vez que isso implica "pagar o custo humano” da intervenção nos casos de genocídio, assassinatos em massa, e limpeza étnica. Isso representa um grande desafio para a teoria solidarista da sociedade internacional, para a qual "the conception solidarist of ethical statecraft requires state leaders in exceptional cases of supreme humanitarian emergency to risk, and if it is necessary to lose, soldiers' lives”. (WHEELER, 2000, p. 300)

No caso da Somália, por exemplo, esse elemento atuou em dois momentos fundamentais, o da decisão de intervir e o da decisão de se retirar do país. A percepção do governo Bush de que a Somália seria uma operação livre de riscos, tanto financeiros quanto humanos, pelas características de seu mandato, foi determinante para a decisão do envio das tropas americanas para liderar a missão de intervenção na Somália. Essa mesma percepção também sustentava o apoio da opinião pública interna americana que, chocada com as imagens em tempo real da situação do povo somali, pressionava o governo para que algo fosse feito. Quando as imagens dos corpos, cruelmente mutilados de jovens soldados do Exército dos EUA, chegaram às casas dos cidadãos americanos pela cobertura da mídia, a mesma pressão da opinião pública doméstica que havia contribuido para a legitimidade do 
envio das tropas à Somália pressionou o governo exigindo a retirada das tropas americanas da missão.

Em Ruanda, a preocupação com a segurança do pessoal da UNAMIR e os temores de um novo número de baixas em uma missão humanitária, após o caso somali, atuaram na decisão do Secretário-Geral, Boutros-Ghali, de ignorar os apelos do comandante da UNAMIR para o envio de mais soldados e para a substituição do mandato de manutenção da paz para um mandato de imposição da paz, a fim de autorizar o uso da força em campo pelas tropas da ONU. No relatório sobre a situação no país, apresentado aos membros do CSNU, BoutrosGhali não só ignorou os apelos do General Dallaire para o fortalecimento do mandato da missão para que as tropas da ONU tentassem impedir o genocídio de tutsis e hutus moderados, como alterou a essência do telegrama de apelo do General informando aos membros do CS de que se tratava de um conflito interno étnico, enfatizando a importância de garantir a segurança do pessoal da Organização. Esse documento influenciou principalmente os membros não permanentes do CS a apoiar a resolução que não autorizou a alteração do mandato da UNAMIR e ainda determinou a retirada dos capacetes azuis do país.

O mesmo receio das baixas militares determinou a opção pelos ataques aéreos em detrimento do emprego de forças militares em campo na intervenção da OTAN no Kosovo. A perspectiva de risco praticamente nula de soldados mortos nessa opção de combate pelos ares recebeu mais peso do que as considerações sobre a efetividade desse tipo de estratégia militar para combater a limpeza étnica dos kosovares que acontecia em campo. A estratégia dos ataques aéreos atuava tão decisivamente na intervenção da Aliança que mesmo após o comprovado recrusdecimento da violência contra os kosovares, que acabou por gerar o maior número de refugiados e deslocados na Europa desde o Holocausto, assim que os bombardeios começaram, não foi suficiente para incluir combates militares em campo na missão. De acordo com Wheeler, a Aliança poderia ter criado uma grande força expedicionária militar na Macedônia e na Albânia, sinalizando a Milosevic que a OTAN estava seriamente comprometida com a defesa dos direitos humanos dos kosovares. (WHEELER, 2000, p. 270)

A relação entre a legitimidade do envolvimento de um Estado nacional em uma intervenção humanitária e a influência direta da opinião pública doméstica desse Estado sob essa legitimidade é a primeira a desequilibrar-se quando acontessem baixas em campo, justamente pela diferença entre uma missão cujo emprego das forças militares é justificado por uma razão humanitária e uma missão que é justificada pelo interesse nacional. Por isso, os Estados nutrem uma grande preocupação com relação ao custo humano dessas missões no 
momento em que precisam considerar a decisão de intervir em territórios distantes e inóspitos para salvar a vida de estrangeiros.

A razão da polêmica e da dificuldade de lidar com a morte de soldados nacionais em territórios externos às fronteiras do Estado com a finalidade de garantir a vida e os direitos básicos de estrangeitos está na própria função do Estado nacional e na utilidade de atribuir o monopólio do uso da força a esse Estado, para que ele seja o guardião e o responsável por garantir o objetivo primário da comunidade política, ou seja, sua própria sobrevivência.

Nesse sentido, a moralidade cosmopolita que fundamenta a norma da intervenção por motivos humanitários amplia o alcance da função do Estado de proteger seus próprios cidadãos e garantir a observância de seus direitos humanos em direção à responsabilidade desse Estado e de toda a comunidade internacional com a garantia da vida e da proteção dos direitos humanos de qualquer indíviduo, independente de sua nacionalidade. Para tanto, nas situações em que não houver outra opção que não o emprego da força para garantir o exercício dessa responsabilidade, o dever moral intrínseco a uma norma de intervenção humanitária prevê o uso da força, mesmo que isso implique em baixas militares.

Para a teoria realista, os Estados não devem arriscar a vida de seus soldados para salvar a vida de estrangeiros por duas razões: a primeira dela é porque esse risco contraria a função básica do Estado de proteger a vida de seus cidadãos; e a segunda é porque a utilização da força do Estado não deve ser usada em ações que prejudiquem a segurança desse Estado e de seus interesses, sejam econômicos e materiais, seja pelo custo humano e de aprovação política interna proveniente da morte de soldados.

Em sua análise da intervenção humanitária na Somália, Marta Finnemore considerou que o caso havia desafiado seriamente a teoria realista porque que os motivos da decisão americana de intervir não faziam parte do interesse nacional dos EUA. Segundo a autora, “(...) realists fail to recognize that changing norms of legitimate intervention reconstitute state interests making possible intervention on behalf of humanity rather than in the service of strategic or economic interest”. (FINNEMORE, 1996, p. 154) Segundo Wheeler, o fato do governo americano ter anunciado sua retirada do caso, após as baixas de seus soldados, mesmo que estas tenham sido em número relativamente reduzido para uma operação militar em campo, é a razão pelo qual a intervenção na Somália não desafiou a teoria realista. (WHEELER, 2000, p. 202) 
A observação de Marta Finnemore pode ser avaliada sob dois aspectos. De um lado, o alcance dos argumentos realistas como parâmetro da ação internacional havia sido desafiado por essa mudança de normas que legitima as intervenções humanitárias na medida em que os Estados Unidos decidiram usar sua força militar numa ação na qual a razão principal era de fato humanitária, já que não havia quaisquer indícios de que a razão tenha sido ligada à promoção de interesses relacionados ao interesse nacional. Como vimos na apresentação do caso, fatores políticos, como a vontade do então Presidente Bush de encerrar seu governo com um grande feito e desviar as atenções para sua inação na Bósnia, influenciaram na decisão de intervir, porém tais fatores não estavam ligados à obtenção de interesses estratégicos, sejam econômicos ou políticos, referentes à missão na Somália.

Por outro lado, não houve desafio ao argumento realista de que os Estados devem primeiramente buscar sua própria segurança e garantir a segurança de seus cidadãos e, por isso, não devem arriscar a vida de seus soldados nas intervenções humanitárias, uma vez que essa lógica determinou a retirada das tropas da Somália, assim que as baixas militares aconteceram e a própria decisão de intervir, dado que a intervenção na Somália não teria acontecido se Bush acreditasse que isso ameaçava a segurança dos EUA. (DESCH, 1998, p. 140)

Essa diferença na interpretação do quanto o caso da intervenção humanitária na Somália colocou um sério questionamento à teoria realista permite a interpretação de que o caso somali demonstrou a existência de mudança na ação política a partir da alteração do contexto normativo das intervenções humanitárias, iniciado na década de 1990, mas que essa mudança normativa foi (e ainda é) fortemente limitada pela interpretação realista das funções e atribuições do Estado Nacional, que predominantemente orientam a prática política soberana.

A resolução do enigma entre ordem e justiça está presente nessa questão da preservação da vida dos soldados na medida em que mostra a ambigüidade da busca por justiça ser dependente das considerações de ordem e, ao mesmo tempo, a variação caso a caso do quanto à ordem é dependente da justiça. No caso da Bósnia e do Kosovo, os governos ocidentais tinham tanto a obrigação moral quanto o interesse em segurança para arriscar a vida de seus soldados a fim de combater uma emergência humanitária suprema num caso claro em que a ordem dependia significativamente da justiça.

Mas e quanto às catástrofes humanitárias em países africanos distantes, como o genocídio em Ruanda no ano de 1994? “Can it really be argued that the genocide in Rwanda 
posed a threat to Western security interests and wider international order that justified the sacrifice of Western soldiers?” Sim, Wheeler responde. O genocídio em Ruanda poderia ser justificado como uma ameaça à ordem internacional e aos interesses de segurança do Ocidente a partir da concepção de universalismo moral, que torna possível a conexão do Ocidente com a África, numa narrativa de solidariedade em que os problemas das outras pessoas, não importa o quão longe elas estejam, preocupam a todos. (WHEELER, 2000, p. 303)

A intervenção humanitária em Ruanda poderia ter sido realizada com base no universalismo moral, mas a inércia da comunidade internacional demonstrou os limites práticos dessa concepção, já que nem a cobertura da mídia despertou a solidariedade da opinião pública ocidental profundamente. Ruanda mostrou os claros limites do efeito CNN, assim como a distância entre as aspirações do solidarismo e sua realização na prática. (WHEELER, 2000, p. 308)

Os efeitos da globalização econômica na relação entre as arenas do Estado e da economia de mercado, no início da década de 1990, foram interpretados pelos cosmopolitas morais como uma erosão da delimitação das comunidades políticas, nas quais culturas particulares, tradições e modos de viver estavam restritos e protegidos pelas fronteiras do Estado nacional. (HURRELL, 2003, p. 38) Mas, é preciso cuidado perante essa passagem automática de uma interdependência criada pela economia de mercado global e a idéia de comunidade mundial, a partir da erosão dos limites das comunidades políticas.

O principal problema com essa interpretação estaria na dificuldade de relacionar as considerações empíricas de uma crescente unificação do mundo a considerações normativas de emergência de uma comunidade mundial. A falha nessa interpretação estaria, nesse sentido, na incapacidade de distinguir três sensos da idéia de unidade: unidade como interdependência e interconexão; unidade como uniformidade no sentido dos Estados e das sociedades formarem um sistema global; e unidade como consciência de uma humanidade compartilhada ou comprometimento com certo grupo de propósitos compartilhados. Em outras palavras, isso significa dizer que um comércio econômico intenso e denso não pode ser traduzido fácil ou automaticamente em uma consciência compartilhada de uma identidade ou um ethos comum, ou mesmo uma comunidade compartilhada, especialmente se consideramos as enormes desigualdades tanto no sistema internacional contemporâneo quanto no global. (HURRELL, 2000, p.37) 
A paralisia da opinião pública ocidental com relação a Ruanda pode ser entendida, segundo David Miller, a partir da perspectiva de que não há uma forte identidade daquele cidadão nacional de um país com aqueles indivíduos que não são seus nacionais, enquanto há forte ligação e identidade entre o cidadão e o soldado que é seu compatriota. O argumento é que não há motivo suficiente para que um cidadão aceite que seu compatriota morra por um estrangeiro, já que não existe entre esse cidadão e o estrangeiro a forte identidade que a nacionalidade. (MILLER, 1995, apud SHUE, 2004, p. 23)

De acordo com Shue, os indivíduos preferem ver seus filhos morrendo por nacionais e não por estrangeiros, porque esses indivíduos e sua percepção de identidade para com seus compatriotas fazem parte de uma sociedade, na qual o entendimento de justiça foi constituído a partir do elemento nacional. Essa divisão entre o “eu” nacional, para o qual há justiça, respeito dos direitos e da condição humana, e o "outro" estrangeiro, que é uma ameaça à sobrevivência evidencia-se na clássica distinção de Martin Wight entre a sociedade doméstica "as that arena within which understandings of the good life might be debated, developed, and, potentially, realized", e as relações internacionais como "condemned to remain for ever na arena of 'mere survival'”. (WIGHT, 1966, apud WHEELER, 2000, p.35) Então, se o entendimento do que é justo e a sociedade nascem juntos, na sociedade de Estados o que é justo é limitado às fronteiras do Estado.

A partir disso, os nacionais de um Estado poderiam aceitar as mortes de seus compatriotas para proteger indivíduos de qualquer nacionalidade se existe acordo sobre o que é justo e sobre o que é de fato importante modificar. Shue parte da premissa de que todas as pessoas concordam que os seres humanos deveriam ter direitos e que esses direitos deveriam ser protegidos. Assim, proteger esses direitos envolveria, portanto, tomar medidas para garantir essa proteção, o que não é totalmente um dever negativo. (SHUE, 2004, p. 26)

Partindo dessa premissa, Shue entende que, em primeiro lugar, os nacionais precisam saber e apreciar a proteção que vem de fora de sua sociedade; e, em segundo lugar, eles precisam saber e apreciar que os soldados que vão para esse tipo de missão estão sendo chamados a fazer somente o justo compartilhado. Para isso precisa haver (a) um entendimento sensível e claro do que constitui um fair share e (b) a percepção de que nada além do fair share está sendo esperado daquele país e daqueles soldados. (SHUE, 2004, p. 27)

Nessa perspectiva, somente a partir da mudança da percepção compartilhada e do entendimento com respeito à função soberana do Estado, definida pela idéia de soberania como responsabilidade a todos os indivíduos independentemente das fronteiras nacionais é 
que se pode esperar reduzir a distância entre a retórica moral dos líderes ocidentais e o seu comprometimento em sacrificar seus soldados por estrangeiros em perigo. "The real problem is not cost but the lack of a solidarist commitment that could lead governments and citizens to view global firefighting in the same ways as citizens view the provision of a fire service in domestic society”. (WHEELER, 2000, p. 304) 


\section{CONSIDERAÇÕES FINAIS}

"Individuals rather than states have to be the starting point in the
search for global justice".

Charles Beitz, 1979

A investigação do dilema entre a manutenção da ordem e a promoção da justiça nas intervenções humanitárias foi guiada durante todo esse trabalho pela proposição solidarista de Nicholas Wheeler, em sua obra Saving Strangers, do ano de 2000. O argumento que baliza a obra tem como premissa que as intervenções humanitárias da década de 1990 demonstram que uma nova estrutura normativa a respeito dessa prática havia surgido. Enquanto nos casos da década de 1970 - Índia (1971), Vietnã (1979), e Tanzânia (1979) - os argumentos humanitários não faziam parte do grupo de razões legítimas para a intervenção, os casos de intervenção humanitária dos anos 1990 - Somália (1992), Ruanda (1994) e Kosovo (1998) foram aprovados e legitimados pela sociedade internacional a partir de sua motivação humanitária.

Vale lembrar que nos três primeiros casos da década de 1970, tratados no capítulo II, o recurso à força, diante de graves emergências humanitárias, não foi autorizado pela ONU nem legitimado pela sociedade internacional. Apesar do fato de que em todos esses casos, o argumento humanitário poderia ter sido invocado para justificar o uso da força, mas, com a exceção inicial da Índia ${ }^{44}$, os governos preferiram valer-se das interpretações das regras pluralistas (legítima defesa, principalmente), que constituíam as fronteiras aceitáveis de uma ação permissível. Enquanto os últimos três casos de intervenção humanitária, analisados no Capítulo III, demonstraram como a sociedade internacional se tornou mais receptiva aos temas solidaristas na década de 1990, principalmente no que se referiu a intervenção com uso da força, no interior de um Estado soberano, a fim de cessar graves violações dos direitos humanos.

Essa expectativa de um cenário receptivo à mudança normativa com relação às intervenções humanitárias foi confirmada pela 54a Assembléia Geral da ONU, em setembro

\footnotetext{
${ }^{44}$ A Índia desistiu de usar o argumento humanitário em suas tentativas de conseguir uma aprovação do CS à sua decisão de intervir. Para informações adicionais, voltar ao caso na seção 2.6 do Capítulo II.
} 
de 1999, na qual um debate de grande alcance sobre legitimidade e a legalidade das intervenções humanitárias foi realizado. Nessa ocasião, muitos governos utilizaram o argumento, anteriormente inadmissível, de que as considerações de direitos humanos poderiam formar uma base legítima para o CSNU autorizar o uso da força. Kofi Annan, o então Secretário-Geral da Organização, acenava para o desenvolvimento de uma norma internacional de apoio as intervenções. Contudo, essa mudança normativa seria alvo de uma importante limitação, sobre a qual a sociedade de Estados mostra pouco ou nenhum entusiasmo, a legitimação das intervenções humanitárias unilaterais, ou seja, sem a autorização da ONU. (WHEELER, 2000, p. 286)

Ainda nessa Assembléia, o Secretário-Geral da ONU expressou sua preocupação com relação à possibilidade de que intervenções unilaterais, justificadas em bases humanitárias, pudessem erodir as fundações da ordem internacional, o que demonstrava a permanência das normas pluralistas e das objeções e suspeitas realistas como limitação do reconhecimento pela sociedade internacional da legitimidade das intervenções humanitárias unilaterais. De um lado, estava o eco realista de que as intervenções humanitárias são sempre submetidas aos interesses dos mais poderosos; e, do outro lado, o eco pluralista dessa afirmação, para o qual a sociedade de Estados encontra-se muito dividida em suas concepções de justiça para legitimar um direito de intervenção humanitária. (WHEELER, 2000, p. 286)

Os realistas como Chomsky atribuíram a prática de intervenção humanitária dos anos 1990 a um fenômeno de mudança nas relações de poder, em que os Estados Unidos estavam entusiasmados com uma doutrina de intervenção humanitária que se tornou uma ideologia legítima para justificar a proteção do poder dos EUA, necessário para manter sua hegemonia econômica em tempos que a ideologia da Guerra Fria não pode mais servir a esses propósitos. (CHOMSKY, 1999, apud WHEELER, 2000, p. 288)

Tendo em vista o poder das normas e a legitimidade proveniente delas, Wheeler chama a atenção para o fato de que esse argumento de Chomsky ignora que, mesmo se as administrações de Bush e Clinton tivessem invocado justificativas humanitárias, somente por razões veladas, eles se encontrariam constrangidos em suas ações subseqüentes pela necessidade de defendê-las em conformidade com seus argumentos humanitários. Além disso, a visão de que os Estados Unidos e os policy-makers ocidentais manipulam a ideologia legitimadora do humanitarismo para servir a seus interesses ignora a extensão dos argumentos solidaristas nos Estados ocidentais, como resultado de uma mudança normativa em nível doméstico: a pressão pela intervenção humanitária no caso da Somália, por exemplo, veio do 
público doméstico, chocados pelas imagens do sofrimento e das mortes dos somalis famintos, demandando que something be done.

A contínua relutância da sociedade de Estados em conceder um direito de intervenção humanitária unilateral a Estados ou organizações regionais representa a voz pluralista que considera o conflito entre ordem e justiça irreconciliável. Wheeler desconfia desse argumento de não reconciliação entre ordem e justiça e, da percepção pluralista de que a sociedade de Estados de fato acredita que uma doutrina de intervenção humanitária unilateral irá minar os pilares da ordem inter estatal.

"States do disagree over the meaning and priority to be accorded civil,
political, economic, and social rights, but theses controversies should not
obscure the fact that governments have signed up to legal instruments that
commit them to upholding basic standards of humanity. Indeed, no
government questions these normative standards, even when breaching
them, and the dispute is over the means that can legitimately be employed to
enforce theses standards on governments that violate them". (WHEELER,
2000, p. 295)

A resposta de Wheeler à objeção pluralista de que a intervenção humanitária unilateral minaria a ordem internacional recomenda que a sociedade de Estados reconheça a intervenção como exceção aceitável, mas somente naqueles casos em que o interventor conseguir defender legitimamente suas ações como humanitárias. Nessa situação, os Estados ou grupo de Estados teriam que demonstrar a observância daqueles requisitos que conferem legitimidade às intervenções humanitárias, mesmo que sejam unilaterais. (WHEELER, 2000, p. 295)

A despeito da legalidade e da autorização da ONU, Wheeler considera que quando atos de brutalidade ofendem a consciência humana aqueles que têm poder para acabar com tais atos têm a responsabilidade moral de agir. O desafio é explorar as possibilidades de uma terceira via solidarista que legitime a intervenção humanitária quando o CS é impedido de autorizar o uso da força, por causa da ameaça ou uso do veto, e que não coloque em risco as contenções existentes sobre o uso da força. (WHEELER, 2000, p. 294)

Sendo assim, essa terceira via solidarista estaria nesse grupo de condições que pode legitimar uma ação humanitária unilateral desde que o caso de intervenção em questão seja suficientemente convincente para comprovar a existência de uma emergência humanitária suprema; que o uso da força satisfaça os requisitos de necessidade e proporcionalidade; e, por fim, que os motivos e meios utilizados não se choquem minando o resultado humanitário positivo que essa ação deveria gerar. 
A intenção e a função desses critérios de legitimidade das intervenções humanitárias, integrantes dessa terceira via solidarista, parecem remeter à distinção de uma lado entre justiça e justeza em relação aos processos e procedimentos e, por outro, entre justiça e justeza em termos de substância. De acordo com Hurrell, processos justos importam mais do que consensos substantivos, porque é mais difícil alcançar um acordo substantivo tendo em vista a profundidade e a penetração do valor do conflito e, mais ainda, dada a facilidade com a qual as instituições e o Direito Internacional são contaminados por interesses especiais e valores particulares dos mais poderosos. Portanto, a forma mais viável de uma comunidade moral mínima irá continuar sendo aquela que está construída em torno de alguma noção de processo justo. (HURREL, 2003, p. 44)

Essa noção de processo justo seria mais viável devido à estrutura de sentidos compartilhados e da cultura moral compartilhada que tem sido desenvolvida interna e externamente à sociedade internacional, bem como pela universalidade das idéias de um processo justo. Nessa visão de justiça global, a razão e racionalidade não são abstratas e universais, mas são desenvolvidas 'naturally from necessities of social life, that is from the inevitably recurrent conflicts which must be resolved if communities are to survive'.(HAMPSHIRE, 1999, apud HURREL, 2003, p. 45)

Diante da distância que a comunidade internacional está de alcançar esse consenso substantivo a respeito da justiça e de uma moralidade compartilhada e baseada no indivíduo, vide os próprios exemplos de intervenção humanitária da década de 1990 e os outros tantos casos que não chegaram a ser intervenções humanitárias, como a República Democrática do Congo, o Sudão, dentre inúmeros outros, a proposta de Wheeler em Saving Strangers e da CIISE na construção de critérios que ao menos definam um processo justo já pode ser considerada uma contribuição relevante.

Hurrell aponta as deformidades que impedem que uma idéia compartilhada de justiça seja verdadeiramente desenvolvida pela comunidade internacional. A primeira deformidade aparece em termos de distribuição de vantagens e desvantagens, como nas desigualdades maciças da ordem econômica global, no consumo do capital ambiental. A segunda em termos de quem estabelece as normas na sociedade internacional, a partir do fato de que as instituições não são arenas neutras para a solução de problemas comuns, aproximando-se muito mais de arenas de poder ou mesmo de dominância. A terceira deformidade está nas diferenças de capacidade dos Estados e sociedades adaptarem-se às demandas de uma economia global, combinada com a extensão das escolhas econômicas dos países 
desenvolvidos que, se não são ditadas, são certamente formadas pelas instituições dominadas pelos atores mais fortes. Por fim, a quarta e última deformidade diz respeito a capacidade limitada do Direito Internacional e das instituições em constranger efetivamente os atos unilaterais e geralmente ilegais do forte.(HURRELL, 2000, P. 40-1)

O conjunto dessas deformidades indica quais princípios de justiça serão ouvidos e atendidos, bloqueando que procura por princípios de justiça compartilhados e por modos convincentes de basear esses princípios. Nesse sentido, a procura por princípios compartilhados de justiça precisa questionar as condições políticas e sociais para a existência de uma comunidade moral global significativa e o grau no qual eles correspondem ao que de fato existe ou ao que é provável existir.

Em nível geral isso deveria incluir alguma aceitação da igualdade de status, de respeito, e de consideração; algum compromisso com a reciprocidade e a justificação pública das ações; alguma capacidade para um processo decisório autônomo na base de informações razoáveis; um grau de consciência não-coagida para participar; a situação na qual aquele em maior desvantagem se percebe como tendo alguma entrada no sistema; e algum processo institucional pelo qual o mais fraco e em desvantagem é capaz de fazer sua voz ser ouvida e expressar sua reclamação diante de tratamento injusto. (HURRELL, 2003, p. 43)

De acordo com Wheeler, esse caminho de justiça compartilhada depende do desenvolvimento de um novo consenso entre o Ocidente e o Sul, sobre a legitimidade da intervenção humanitária na sociedade de Estados que seja baseado num consenso renovado diálogo entre ricos e pobres. "What is needed is a commitment by the West to the redistribution of wealth, and an acceptance by Southern governments that cases will arise where the slaughter of civilians by their governments is so appalling as to legitimate the use of force to uphold minimum standards of humanity”. (WHEELER, 2006, p. 307)

A renovação dessa relação entre Ocidente e sul poderia começar com um genuíno comprometimento do Ocidente com a justiça distributiva. “The state-centered image of the world has lost its normative relevance because of the rise of global economic interdependence". Hence, principles of distributive justice must apply in the first instance to the world as a whole, and derivatively to nation-states”. (BEITZ, 1999, p. 170) Isso já iniciaria um processo de questionamento à crença profundamente mantida de muitas elites do sul e de sua população de que os Estados ocidentais empregam os motivos humanitários para mascarar sua contínua hegemonia política e econômica. (WHEELER, 2000, p. 307) “Global justice is not something that can be deduced from rational principles, nor can it be reflective 
of a single world view, religious or secular; it is, rather, a negotiated product of dialogue and deliberation and therefore always subject to revision and re-evaluation”. (HURRELL, 2003, p. 45)

Mesmo diante desses problemas e dessas deformidades da ordem política internacional, os argumentos humanitários cujo cerne estão numa moralidade de e para o indivíduo foram mobilizados e supostamente temidos pela estrutura pluralista que pretendia manter os padrões de comportamento em relação ao princípio de soberania e as normas de não-intervenção e não-uso da força. A consideração de tomar as intervenções humanitárias como norma, isto é, como padrão de comportamento legítimo foi vista como ameaça e indício de um dilema entre a manutenção da ordem e a busca por justiça nas relações internacionais.

Esse suposto dilema irreconciliável entre ordem e justiça evidenciado pelas intervenções humanitárias, segundo o ponto de vista pluralista foi reinterpretado pela proposta solidarista numa tentativa de reconciliar ordem e justiça, reposicionando e elevando a justiça ao mesmo patamar da ordem, sem que isso representasse um conflito entre ambas ou uma ameaça à manutenção da última. "There is a good reason to endorse a solidarist claim that a foreign policy that places the defence of human rights at the centre of its ethical code will make an important contribution both to protecting national interests and to strengthening the pillars of international order". (WHEELER, 2003, p. 301) O que a proposta solidarista reivindica é que a mudança de normas proveniente dessa moralidade cosmopolita possa reconciliar ordem e justiça, por meio das intervenções humanitárias.

Desse modo, os critérios mínimos e adicionais tanto os formulados por Wheeler quanto aqueles do relatório “Responsabilidade de Proteger” representam essa tentativa de demonstrar que a justiça referente às intervenções humanitárias não representa de fato uma ameaça à ordem internacional, primeiro porque a ação nas intervenções humanitárias geralmente integra as motivações referentes ao interesse nacional, à promoção da ordem internacional, e à imposição dos direitos humanos. Em segundo lugar porque idealmente a intervenção irá sempre operar com a autorização do CS e, somente quando isso não for possível, ela poderá ser unilateral desde que tenha satisfeito os critérios que a legitime como exceção às normas de não-intervenção e não-uso da força.

Sendo assim, o dilema nas intervenções humanitárias para os pluralistas não está na ameaça à ordem, mas sim nos constrangimentos normativos que essa nova estrutura, também normativa, impõe aos Estados. Não é a suposta ameaça aos pilares da ordem que os Estados temem, mas a possibilidade de ter que arcar econômica e humanamente para intervir mesmo 
onde não haja relevantes interesses políticos e estratégicos envolvidos, caso uma norma de intervenção humanitária unilateral seja, de fato, incorporada às atuais normas internacionais da sociedade de Estados. A questão envolve mais o temor da legitimidade e do poder de constrangimento dessa nova norma do que propriamente a uma real ameaça à ordem. A questão é admitir que há poder bruto, mas também há um poder que vem das normas. Referindo-se à incapacidade do realismo de lidar com as normas, Wheeler afirmou:

“(...) that it does not sufficiently distinguish between power that is based on relations of domination and power that is legitimate because it is based on shared norms. A good example of this is the shaming power of humanitarian norms, which is a form of power not derived from the political and economic hegemony of Western states; rather, it stems from the fact that even repressive governments recognize the need to legitimate their actions as being in conformity with global human standards.”(WHEELER, 2000, p. 290)

A conclusão é que a proposta normativa solidarista não é limitada, mas sim prematura, já que os líderes estatais não querem correr os riscos morais de criar essa norma ou mesmo uma doutrina no Direito Internacional que daria substância prática à necessidade da humanidade fazer mais pelos indivíduos em perigo ao redor do mundo. (WHEELER, 2000, p. 309) Além disso, o projeto solidarista, ainda muito recente, está inserido na ordem de Westphalia, o que significa que o modelo de governança solidarista e cosmopolita coexiste com a velha ordem westphaliana. (HURRELL, 2003, p. 41) Essa convivência é que torna esses movimentos normativos progressivos “mancos”, pois de um lado eles são promovidos dentro de instituições que ainda refletem hierarquia e diferença, e por outro, eles são feitos na base de um solidarismo ainda frágil. (FOOT, 2003, p. 09)

Esses movimentos são ainda tão mancos e prematuros que não é preciso mais do lembrar o caso do Congo, com o qual iniciamos esse trabalho para demonstrar a distância entre a retórica do compromisso moral com os direitos humanos e a prática das intervenções humanitárias, como imposição desse compromisso.

"The global political order remains heavily structured around inherited pluralist mechanisms that are, by any standards, deficient and deformed, certainly when measured by the values to which international society aspires but very often even by the more minimalist goals and values of the earlier period”. (HURRELL, 20003, p. 48)

O conflito no Congo tem entre suas causas a ausência de um comprometimento com um mandato de uma intervenção humanitária de longo-prazo no caso de Ruanda. "Nearly a decade later, the Rwanda genocide can be seen as a cataclysm that both precipitated and reflected many aspects of the massive ethnic and political violence that has shaken Rwanda, 
Burundi, the Democratic Republic of Congo, and other countries throughout Central Africa for years”. (SHATTUCK, 2003, p. 25)

"If the 1994 killing of 700,000 moderate Hutus and Tutsis by extremist Hutus in Rwanda constituted genocide, what will it take for the international community to recognise that genocide is happening in Congo and to pursue those responsible? (...) The unfolding genocide is a legacy of the Clinton administration and the biggest moral failure of the Bush administration. It is time for the world to act”. ${ }^{45}$ (RENZAHO, 2008)

O apelo para que o mundo faça alguma coisa no Congo, ainda permanece só um apelo. A diferença, no entanto, é a seguinte: a despeito de como os Estados se comportam frente às emergências humanitárias graves e à sua responsabilidade de proteger os indivíduos onde quer que eles estejam pela intervenção humanitária, ao menos já se sabe como eles deveriam agir.

\footnotetext{
${ }^{45}$ RENZAHO, Andre M. N. 'How we can stand by as genocide again threatens the Congo?’ The Age, 03/11/08.
} 


\section{REFERÊNCIAS BIBLIOGRÁFICAS}

ANNAN, Kofi. Facing Humanitarian Challenge: Towards a Culture of Prevention. New York: United Nations Dept. of Public Information, 1999.

ARON, Raymond. Paz e Guerra entre as Nações. Brasília: UnB/IPRI. São Paulo: Imprensa Oficial do Estado de São Paulo, 2002.

BARNETT, Michael; FINNEMORE, Martha. Rules for the World: International Organizations in Global Politics. Ithaca and London: Cornell University Press, 2004.

BEITZ, Charles. Political Theory and International Relations. Princeton: Princeton University Press, 1999.

BOOTH, Ken. Human wrongs and international relations. International Affairs, vol.71, $\mathrm{n}^{\circ} 1$, 1995.

BOUCHER, David. Political Theory of International Relations. From Thucydides to the Present. New York: Oxford University Press, 1998.

BOUTROS-GHALI, Boutros. An agenda for peace. Preventive diplomacy, peacemaking and peace-keeping. UN Doc. A/47/277 S/24111, 1992. Disponível em: http://www.un.org. Acesso em: 20 set. 2003.

1993, 1999.

. Empowering the United Nations. Foreign Affairs, 71 (5): 99, Winter 1992-

. Letter from the Secretary-General addressed to the President of the Security Council. UN S.24868, 1992. Disponível em: http://www.un.org. Acesso em: 11 nov. 2007.

BULL, Hedley. 'Society and Anarchy in International Relations'. In: BUTTERFIELD, H.; WIGHT, M. (eds.) Diplomatic Investigations: Essays in the Theory of International Politics. London: Allen and Unwin, 1966.

. 'The Grotian Conception of International Society'. In: BUTTERFIELD, H.; WIGHT, M. (eds.). Diplomatic Investigations: Essays in the Theory of International Politics. London: Allen and Unwin, 1966.

Oxford UP, 1985.

; WATSON, Adam (eds.). The Expansion of International Society. New York:

(ed.) Intervention in World Politics. Oxford: Oxford University Press, 1984.

. The Anarchical Society: a Study of Order in World Politics. London:

Macmillan, 2002. 
BUZAN, Barry. From international to world society?: English School Theory and the social structure of globalization. Cambridge: Cambridge University Press, 2004.

CARR, Edward H. Vinte anos de crise: 1919-1939. Brasília: Editora da Universidade de Brasília, 1981.

CIISE, David. A responsabilidade de proteger. Relatório da Comissão Internacional sobre Intervenção e Soberania do Estado. Toronto: IDRC books, 2002.

CLARK, Ian. Reform \& Resistance in the International Order. Cambridge: Cambridge University Press, 1980.

COHEN, Marshall. 'Moral Skepticism and International Relations'. A Philosophy \& Public Affairs Reader. In: BEITZ, C.; COHEN, M.; SCANLON, T.; SIMMONS, A. J. International Ethics. Princeton: Princeton University Press, 1985.

DESCH, M. 'Culture Clash: Assessing the Importance of Ideas in Security Studies', International Security, 23/1, 1998.

DONNELLY, Jack. Direitos Humanos Internacionais: Conseqüências Não Intencionais da Guerra contra o Terrorismo. Contexto Internacional. Rio de Janeiro, vol. 25, n 2, julho/dezembro, 2003.

University Press, 2003.

Universal Human Rights in Theory and Practice. Ithaca: Cornell 'The Social Construction of Human Rights'. In: DUNNE, T., WHEELER, N. J. (eds.). Human Rights in Global Politics. Cambridge: Cambridge University Press, 1999.

DOYLE, Michael. ‘The New Interventionism'. In: POGGE, Thomas W. (ed.) Global Justice. Blackwell Publishers, 2001.

DUNNE, Tim; WHEELER, Nicholas. Human rights in global politics. Cambridge: Cambridge University Press, 2001.

Macmillan, 1998.

Inventing International Society: A History of English School. London:

ESTEVES, Paulo. Para uma genealogia do Estado Territorial Soberano. Revista de Sociologia e Política, n 27, 15-32 nov., 2006.

; SEIXAS, Camila do Couto. Ordem e Justiça na sociedade internacional: os impactos humanitários das sanções econômicas multilaterais. In: SOUZA, Matilde de (org.) (2004) A agenda social das relações internacionais. Belo Horizonte: Editora PUCMinas, 2004.

FALK, Richard. Human Rights Horizons. The Pursuit of Justice in a Globalization World. New York-London: Routledge, 2000. 
FIGUEIREDO, Marcos Vinícius Mesquita Antunes de. Direitos humanos, interdependência moral e a redefinição do uso da força pelo Conselho de Segurança das Nações Unidas: o caso do UNPROFOR. Dissertação (mestrado) - Rio de Janeiro: PUC-Rio, Instituto de Relações Internacionais, 2006.

FINNEMORE, Martha. Constructing Norms of Humanitarian Intervention. In: Katzenstein, P. (eds.). The Culture of National Security. Columbia: Columbia University Press, 1996.

; SIKKINK, Kathryn. 'International Norm Dynamics and Political Change'. International Organisation, 52:4, 1998.

. The Purpose of Intervention: changing beliefs about the use of force. Ithaca and London: Cornell University Press, 2003.

FONSECA Jr., Gelson. A legitimidade e outras questões internacionais. São Paulo: Paz e Terra, 1998.

GRAHAN, Gordon. Ethics and International Relations. Malden: Blackwell Publishing, 2008

HOLZGREF, J. L.; KEOHANE, Robert O. (eds.). Humanitarian Intervention: Ethical, Legal and Political Dilemmas. Cambridge: Cambridge University Press, 2003.

HURRELL, Andrew. Order and Justice in International Relations: What is at Stake? In: FOOT, Rosemary; GADDIS, John; HURRELL, Andrew. (eds) Order and Justice in International Relations. New York: Oxford University Press, 2003.

JACKSON, Robert. Quasi-states: sovereignty, international relations and the Third World. Cambridge: Cambridge University Press, 1990

Oxford UP, 2000b.

The Global Covenant: Human Conduct in a World of States. New York:

KOSKENNIEMI, Martti, 'The Police in the Temple. Order, Justice and The UN: A

Dialectical View’. European Journal of International Law, 6, 1995.

KRATOCHWIL, F. Rules, Norms and Decisions: On the Conditions of Practical and Legal Reasoning in Interational Relations and Domestic Affairs. Cambridge: Cambridge University Press, 1989.

. 'Sovereignty as Dominium: Is there a Right of Humanitarian

Intervention?'.In: GENE, Lyons; MASTANDUNO (eds.). Beyond Westphalia? State

Sovereignty and International Intervention. Baltimore: Johns Hopkins University Press, 1995.

LINKLATER, Andrew.'What is a Good International Citizen?' In: KEAL, P. (ed.). Ethics and Foreign Policy. Canberra: Allen\& Unwin, 1992.

; SUGANAMI, Hidemi. The English School of International Relations. A Contemporary Reassessment. Cambridge: Cambridge University Press, 2006. 
LYONS, G. M. \& MASTANDUNO, M. Beyond Westphalia? State Sovereignty and International Intervention. Baltimore: Johns Hopkins University, 1995a.

LYONS, T., SAMATAR, A. Somalia: State Collapse, Multilateral Intervention, and Strategies for Political Reconstruction. Washington: Brookings Institute, 1995.

MAYALL, James. Humanitarian Intervention and International Society: Lessons from Africa. In: WELSH, Jennifer. Humanitarian Intervention and International Relations. New York: Oxford University Press, 2004.

The New Interventionism 1991-1994. United Nation Experience in Camboja, former Yugoslavia and Somalia. Cambridge: Cambridge University Press, 1996.

MORGENTHAU, Hans J. A política entre as nações. A luta pelo poder e pela paz. São Paulo: Imprensa Oficial do Estado de São Paulo, Editora Universidade de Brasília, Instituto de Pesquisa de Relações Internacionais, 2003.

NICOLAIDIS, Kalipso; LACROIX, Justine. Order and Justice Beyond the Nation-State: Europe's Competing Paradigms. In: FOOT, Rosemary; GADDIS, John; HURRELL, Andrew. (eds) Order and Justice in International Relations. New York: Oxford University Press, 2003.

NOGUEIRA, João Pontes. "Estado, Identidade e Soberania na Intervenção da ONU na Somália”. Contexto Internacional. Rio de Janeiro, vol. 19, nº 1, pp. 131-150, 1997.

A Guerra do Kosovo e a desintegração da Iugoslávia: Notas sobre a (re) construção do Estado no fim do Milênio. Revista Brasileira de Ciências Sociais, Vol. 15 n 44, 2000 .

; MESSARI, Nizar. Teoria das Relações Internacionais: Correntes e Debates. Rio de Janeiro: Editora Campus, 2005.

NYE, Joseph S. Understanding International Conflicts. An Introduction to Theory and History. New York: Pearson Longman, 2008.

PAREKH, B. 'Rethinking Humanitarian Intervention', International Political Science Review, 18/1, 1997.

PUGH, Michael. 'Peacekeeping and Humanitarian Intervention'. In: WHITE, Brian; LITTLE, Richard; SMITH, Michael (ed.) Issues in World Politics. Palgrave Macmillan, 2001.

RAWLS, John. Justiça como equidade - uma reformulação. São Paulo: Martins Fontes, 2003.

RENZAHO, Andre M. N. 'How we can stand by as genocide again threatens the Congo?', The Age, Nov. 2008.

ROBERTS, A. 'Humanitarian War: Military Intervention and Human Rights', International Affairs, 69/3, 1993. 
. Order/Justice Issues at the United Nations. In: FOOT, Rosemary; GADDIS, John; HURRELL, Andrew. (eds.) Order and Justice in International Relations. New York: Oxford University Press, 2003.

RODRIGUES, Simone Martins. Segurança internacional e direitos humanos: a prática da intervenção humanitária no pós-Guerra Fria. Rio de Janeiro: Renovar, 2000.

SHATTUCK, John. Freedom on fire. Human Rights Wars and America's Response. Cambridge: Harvard University Press, 2003.

SHUE, Henry. 'Limiting Sovereignty'. In: WELSH, Jennifer. Humanitarian Intervention and International Relations. New York: Oxford University Press, 2004.

. Basic Rights: Subsistence Affluence and US Foreign Policy. Princeton:

Princeton University Press, 1980

SILVA, Alexandre dos Santos. A intervenção Humanitária em três quase-Estados africanos: Somália, Ruanda e Libéria. Dissertação (Mestrado). Rio de Janeiro: Pontifícia Universidade Católica do Rio de Janeiro, Instituto de Relações Internacionais, 2003.

SOUZA, Emerson Maione de. A Contribuição e o Desenvolvimento da Escola Inglesa de Relações Internacionais. Dissertação (Mestrado). Rio de Janeiro: Pontifícia Universidade Católica do Rio de Janeiro, Instituto de Relações Internacionais, 2003.

THAKUR, Ramesh. The United Nations, Peace and Security. Cambrigde: Cambridge Universtity Press, 2006.

VINCENT, R. J. Human rights and international relations. Cambridge, Cambridge University Press, 1986.

VITA, Álvaro de. Justiça Liberal: argumentos liberais contra o neoliberalismo. Rio de Janeiro: Paz e Terra, 1993.

WALZER, M. Just and Unjust Wars: A Moral Argument with Historical Illustrations. London: Allen Lane, 1978. . Spheres of Justice. New York: Basic Books, 1983.

WELCH, C. “The OUA and Human Rights: Towards a New Definition”. Journal of Modern African Studies, 19/3, 1981.

WELSH, Jennifer M. Humanitarian Intervention and International Relations. New York: Oxford University Press, 2004.

WENDT, A. Social Theory of International Politics. Cambrigde: Cambridge Universtity Press, 1999.

WHEELER, Nicholas. Agency, Humanitarianism and Intervention. International Political Science Review, vol.18, nº1, 1997. 
York: Oxford, 2000.

Saving strangers. Humanitarian Intervention in International Society. New

The Humanitarian Responsabilities of Sovereignty: Explaining the Development of a New Norm of Military Intervention for Humanitarian Purposes in International Society. In: WELSH, Jennifer. Humanitarian Intervention and International Relations. New York: Oxford University Press, 2004.

WIGHT, Martin. Why Is There No International Theory? In: BUTTERFIELD, H.; WIGHT, M. (eds.). Diplomatic Investigations: Essays in the Theory of International Politics. London: Allen and Unwin, 1966.

ZANETTI, Véronique. 'Global Justice: is interventionism desirable?’ In: POGGE, Thomas W. (ed.) Global Justice. Blackwell Publishers, 2001. 